The role of cell apoptosis on in vitro produced beef cattle embryos

$$
\text { By }
$$

\title{
Marble Nkadimeng
}

Submitted in partial fulfilment of the requirements for the degree

\author{
MSc (Agric) Animal science
}

Faculty of Natural and Agricultural Sciences

Department of Animal and Wildlife Sciences

University of Pretoria

South Africa

2016 
The role of cell apoptosis on in vitro produced beef cattle embryos

By

Marble Nkadimeng

Promoter:

Dr KC. Lehloenya

Co-Promoter:

Prof E. van Marle-köster

Co-promoter:

Prof TL. Nedambale

Department:

Animal and Wildlife Sciences

Degree:

MSc (Agric) Animal Science

2016 


\section{Declaration}

I, Marble Nkadimeng declare that the dissertation, which I hereby submit for the degree MSc. Animal Science at the University of Pretoria, is my own work and has not previously been submitted by me for a degree at any other tertiary institute

Signature.

Date. 


\section{Acknowledgments}

To my heavenly Father, thank you for the strength and wisdom to pull through this journey.

I would like to express my deepest gratitude to my parents, Petrus and Annah Nkadimeng, my siblings, Collins, Kholofelo and Tsholofelo Nkadimeng for their support and guidance, I am what I am today because of you.

To my Supervisors, Dr Lehloenya, Prof van Marle-köster and Prof Nedambale. Thank you very much for your countless support and guidance from the beginning till the end, I cannot express how much I appreciate it.

I would like to thank the love of my life, Solomon, kgaogelo and Khumo Makgata for the love, understanding and devotion over these years. Without you I would be lost on this great journey of life.

To my brother Sizwe Makola, my cousin Matilda Makuwa, sister in-law Mphumelelo Makgata and my friend Mokgadi Seshoka, thank you for your motivational words that keeps me going day by day throughout this journey.

Finally, I would like to thank the Technology Innovation Agency and Southern African Science Service Centre for Climate Change and Adaptive Land Management - Council for Scientific and Industrial Research for funding this project, to the colleagues at GCRB unit, thank you very much for your support. 


\begin{abstract}
The in vitro culture environment of cattle embryos can compromise the survival of developing embryos resulting in cell apoptosis. Detection of cell apoptosis is important for determining embryonic quality and reducing embryonic mortality in female animals prior to transfer. In this study the role of cell apoptosis on in vitro embryos was studied, with the focus on oocyte maturation and embryo production, caspase- 3 activity and DNA fragmentation. Cow ovaries were collected from local abattoir and a total of 900 COCs were retrieved per week for the study over five-month period (six replicate/per experiments). COCs were randomly allocated to four incubation temperatures $(39,41$, 42 and $43^{\circ} \mathrm{C}$ ) for polar body extrusion. Based on maturation results, two preferred temperatures (39 and $41{ }^{\circ} \mathrm{C}$ ) were selected for maturation. Oocytes were subjected to normal subsequent embryonic conditions post maturation. Embryos produced from both maturation temperatures were then examined for embryonic development, caspase-3 activity and DNA fragmentation for evidence of apoptosis. No difference was $(\mathrm{P}<0.05)$ observed in embryonic development between oocytes matured at $39^{\circ} \mathrm{C}$ and $41{ }^{\circ} \mathrm{C}$ respectively. Blastocysts produced at $39{ }^{\circ} \mathrm{C}$ showed significantly $(P<0.05)$ higher nuclei cells compared to those produced from $41{ }^{\circ} \mathrm{C}$ matured oocytes. A higher $(\mathrm{P}<0.05)$ caspase-3 activity and DNA fragmentation were observed at $(2-4$ cell) and ( $\geq$ 8cell cell) embryos for $41{ }^{\circ} \mathrm{C}$ matured oocytes compared to $39{ }^{\circ} \mathrm{C}$ maturation group. A significantly higher caspase-3 activity and DNA fragmentation on blastocyst produced at $41{ }^{\circ} \mathrm{C}$ matured oocytes were also evident compared to those produced at $39{ }^{\circ} \mathrm{C}$. Although embryos produced from oocytes matured at $41{ }^{\circ} \mathrm{C}$ showed similar developmental capacity to embryos from $39{ }^{\circ} \mathrm{C}$, this study showed that a higher incidence of apoptosis can be expected in embryos produced from oocytes matured at a higher $\left(41^{\circ} \mathrm{C}\right)$ temperature than $39^{\circ} \mathrm{C}$.
\end{abstract}




\section{Table of Contents}

Declaration

Acknowledgments

Abstract

List of Table iii

List of abbreviations

Chapter 1

1.1. Introduction.

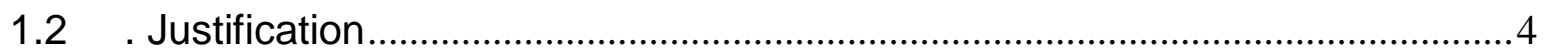

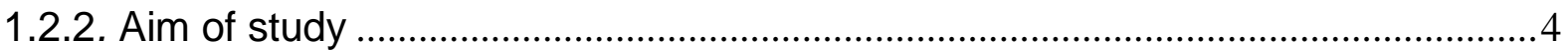

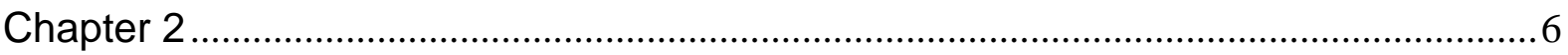

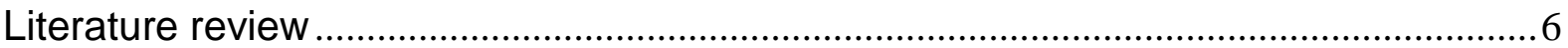

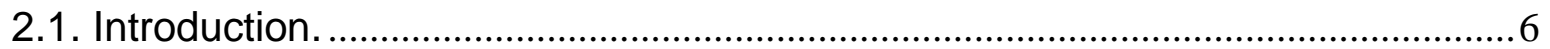

2.2. Overview of in vitro embryo production in the beef cattle industry. ....................6

2.3. Genetic regulation and action of in vitro embryo production. ............................. 10

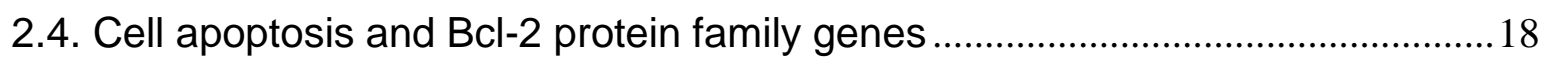

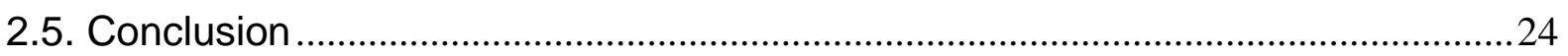

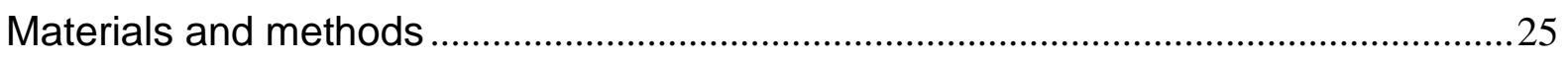

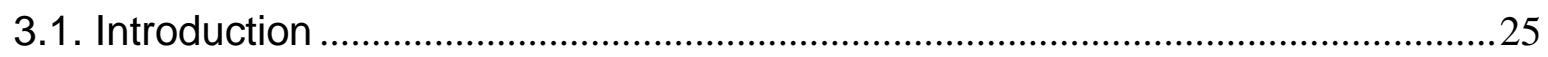

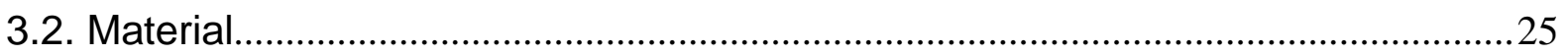

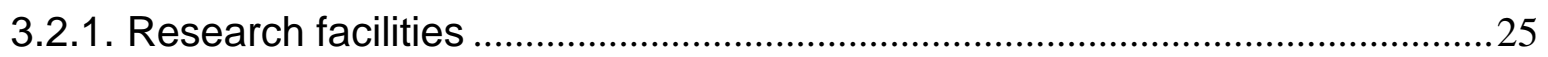

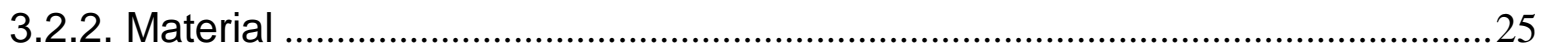

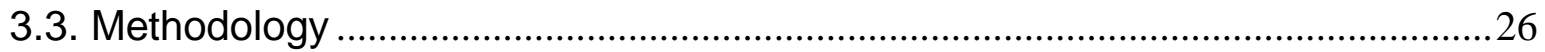

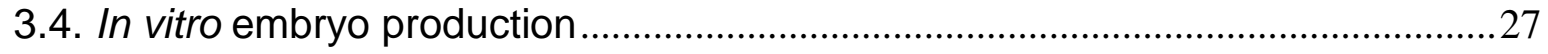

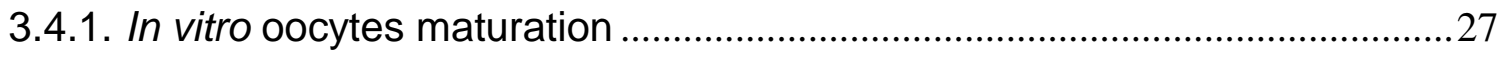

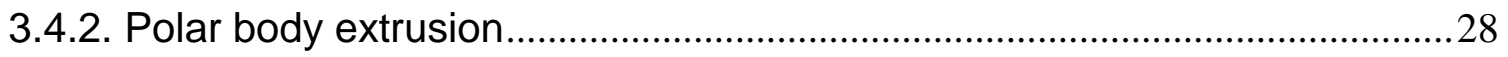

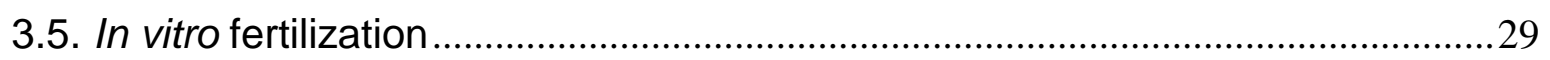

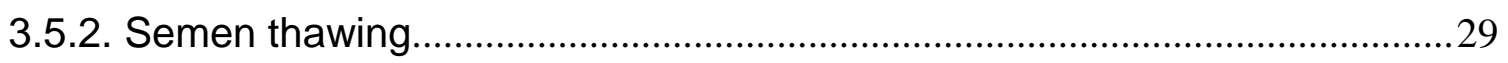

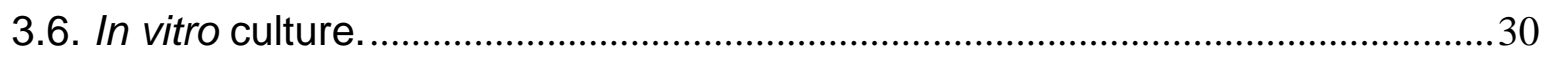

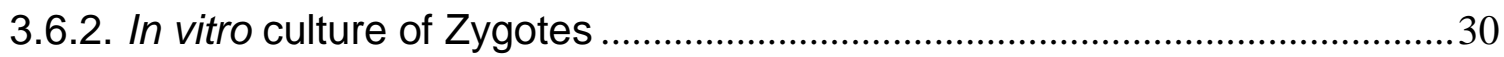

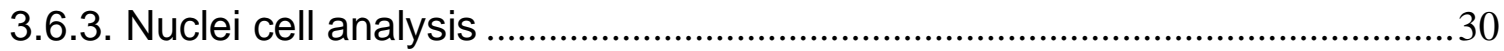

3.7. Caspase-3 activity of produced embryos from oocytes matured at two (39 and $41^{\circ} \mathrm{C}$ ).

38. DNA fragmentation of produced embryos from oocytes matured at two (39 and $\left.41^{\circ} \mathrm{C}\right)$

3.9. Statistical analysis 
Chapter 4 .34

Results

4.1. Introduction .34

4.2. In vitro oocytes maturation 34

4.3. In vitro embryo production and nuclei cell analysis .35

4.3. Caspase- 3 activity of produced embryos from oocytes matured at two ( 39 and $\left.41^{\circ} \mathrm{C}\right)$.

4.4. DNA fragmentation of produced embryos from oocytes matured at two (39 and $\left.41^{\circ} \mathrm{C}\right)$.

Chapter 5 41

Discussion. .41

5.1. Introduction .41

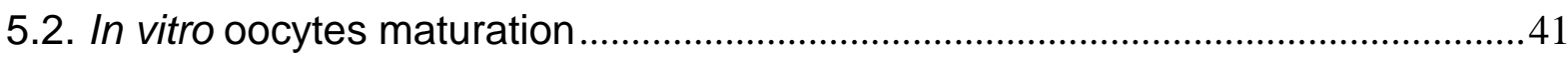

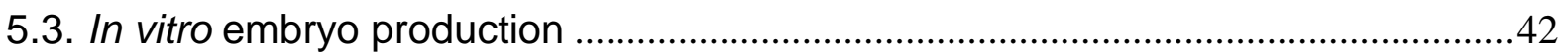

5.4. Nuclei cell analysis of produced blastocyst

5.5. Caspase -3 activity of produced embryos from oocytes matured at two ( 39 and $\left.41^{\circ} \mathrm{C}\right)$.

5.6. DNA fragmentation of produced embryos from oocytes matured at two (39 and $\left.41^{\circ} \mathrm{C}\right)$. 45

CHAPTER 6 .47

Conclusion .47

References 


\section{List of Table}

Table 2.1 List of gene transcript in cattle oocytes and embryos related to their function throughout prei-mplatation development.

Table 2.2 Illustration of oocyte growth and gene indication genes associated with each developmental stage 13

Table 2.3 Expressed transcript after the major activation of embryonic genome..... 14

Table 2.4 Difference in gene transcripts on bovine embryos produced in culture medium ( $\mathrm{T}$ 199) with different supplements 15

Table 2.5 Subcellular localization of BCL-2 family members in the gene bank 19

Table 3.1 Shows summary of primary activity for the four experiments. 26

Table 4.1 Maturation of cattle oocytes at incubation four temperatures $\left(39^{\circ} \mathrm{C}, 41^{\circ} \mathrm{C}, 42^{\circ} \mathrm{C}\right.$ and $\left.43^{\circ} \mathrm{C}\right)$

Table 4.2 In vitro embryo development of matured oocytes at $39^{\circ} \mathrm{C}$ and $41^{\circ} \mathrm{C}$ incubation temperature.

Table 4.3 Caspase activity at different cattle embryos stages produced in vitro embryo 37

Table 4.4 Represent the results from detection of DNA fragmentation using tunel assay. 38

Table 4.5 Tunel assay indexis on day 7 cattle blastocyst produced in vitro 39 


\section{List of figures}

Figure 2.1 Summary of the international Embryo Transfer Society stastistical data collected by the data retrieval committee.

Figure 2.2 Represent Induction of apoptosis in the mammalian cell via the mitochondrial pathway 21

Figure 3.1 Beef cattle ovaries (ARC- Germplasm Reproduction Biotechnologies (GCRB) lab).. 27

Figure 3.2 Aspiration method of oocytes retrieval (ARC- GCRB lab) 27

Figure 3.3 Bovine oocytes in vitro maturation performed at the ARC lab, GCRB section. 28

Figure 3.4 Hoechest blastocyst staining using Computer Sperm Analyser® (Barcelona, Spain) GCRB lab. 31

Figure 3.5 Microplate reader ARC-Nutrition section lab 33

Figure 4.1 (A) Matured oocytes from $41^{\circ} \mathrm{C}$ and (B) Matured oocytes from $39^{\circ} \mathrm{C}$ 35

Figure 4.2 Matured oocytes at $(\mathrm{A}) 42{ }^{\circ} \mathrm{C}$ and $(\mathrm{B}) 43^{\circ} \mathrm{C}$ maturation temperature 35

Figure 4.3 (A) Day 7 Blastocyst from oocytes produced $39^{\circ} \mathrm{C}$ and (B) Day 7 Blastocyst at $41^{\circ} \mathrm{C}$ 36

Figure 4.4 (Hoechst 33323) Stained blastocyst from $39^{\circ} \mathrm{C}(\mathrm{A})$ and $(\mathrm{B}) 41^{\circ} \mathrm{C}$.... 36

Figure 4.5 (A) Non-fragmented 2-4 cell embryos from $41^{\circ} \mathrm{C}$ and (B) Non-fragmented 2-4 cell from $39^{\circ} \mathrm{C},(\mathrm{C})$ fragmented $2-4$ cell embryo from $41^{\circ} \mathrm{C}$ and $(\mathrm{D})$ fragmented $2-4$ cell embryo from $39^{\circ} \mathrm{C}$.

Figure 4.6 (A) Non-fragmented $\geq 8$ cell from both $41^{\circ} \mathrm{C}$ and $39^{\circ} \mathrm{C}$ and (B) Fragmented $\geq 8$ cell from both $41^{\circ} \mathrm{C}$ and $39^{\circ} \mathrm{C}$

Figure 4.7 (A \& B) Non-fragmented blastocysts from oocytes matured $39^{\circ} \mathrm{C}$ and $41^{\circ} \mathrm{C},(\mathrm{C}$ \&D) Fragmented blastocysts from oocytes matured at both $39^{\circ} \mathrm{C}$ and 41 


\section{List of abbreviations}

ART

Apaf-1

Bad

Bak

Bax

Bcl-2

$\mathrm{Bcl}-\mathrm{XL}$

Bid

$\mathrm{BO}$

Bok

BSA

${ }^{\circ} \mathrm{C}$

cOCs

$\mathrm{CO}_{2}$

CX 43

DPBS

DNA

DNase

dsDNA

EGA

ET

EST

FBS

$\mathrm{FSH}$

$\mathrm{G} 6 \mathrm{PH}$

GLUT1

$\mathrm{H}_{2} \mathrm{O}_{2}$

HSP

HPRT

ICAD

IVM

IVM

IVF
Assisted reproduction biotechnologies

Apoptosis protease activating factor-1

Bcl-2 Associated agonist of cell death

Bcl-2-antagonist/killer 1

$\mathrm{Bcl}-2$-associated $X$ protein

B cell CLL/lymphoma 2

B-cell lymphoma -extra large

Interacting domin death agonist

Bracket and Oliphant

$\mathrm{Bcl}-2$ related ovarian killer

Bovine serum albumen

Celcius

Cumulus oocyte complexes

Carborn dioxide

Connexin 43 gene

Dulbecco phosphate buffer saline

Deoxyribonucleic acid

deoxyribonuclease

Double-stranded deoxyribonucleic acid

Embryonic genome activation

Embryo transfer

Estradiol hormone

Fetal bovine serum

Follicular stimulating hormone

Glucose-6-phosphatate dehydrogenase

Glucose transporter 1

Hydrogen peroxide

Heat shock proteins

Hypexanthine-guanine phosphoribosyl transferase

Inhibitor of caspase activated deoxyribonuclease

In vitro maturation

In vitro culture

In vitro fertilization 
IVP

$\mathrm{LH}$

LOS

$\mathrm{Mcl}-1$

MDPBS

MOET

$\mathrm{O}_{2}$

OPU

PBS

PBS-PVP

ROS

RPM

SOF-BSA

SOF-FBS

TDT

TCM

TP53
In vitro embryo production

Luteinizing hormone

Large offspring syndrom

Myeloid cell leukemia

Modified dulbecco phosphate buffer saline

Multiple ovulation and embryo transfer

Oxygen

Ovum pick up

Phosphate buffer saline

Phosphate buffer saline-polyvinylpyrrolidone

Reactive oxygen species

Revolution per minute

Synthetic oviductal fluid- bovine serum albumen

Synthetic oviductal fluid - fetal bovine Serum

Terminal teoxynucleade tansferase reaction

Tissue culture mediu

Tumour protein 53 


\section{Chapter 1}

\subsection{Introduction}

Reproductive inefficiency is one of the most important causes of economic losses in livestock industries and it is realized throughout the world (Verma et al., 2012). Therefore, there is a need for application of reproduction biotechnologies in livestock to aid in animal improvement. Reproductive biotechnologies are useful for solving possible reproductive failures. Thus, Assisted Reproductive Technologies (ART) have been developed and refined to obtain large number of offspring from genetically superior animals or obtain offspring from infertile or subfertile animals (Widayati, 2012). The first biotechnology procedure used to improve reproduction and accelerate genetic improvement of livestock was artificial insemination (AI), followed by MOET (Multiple Ovulation and Embryo Transfer) and in vitro fertilization (Niemann \& Kues, 2003). Development of reproductive technologies such as; estrus synchronization, superovulation, non-surgical embryo collection, and cloning to name a few are more recent assisted reproduction technology tools used in improvement of livestock production (Hafez, 2015). However, the common goal of all the biotechnologies is to provide highly reliable mechanism to produce superior livestock which can help animals of average productivity (Jennifer et al., 2013). These technologies (AI, MOET and IVP) have been evolving throughout the years based on their effectiveness with regards to male and female fertility.

The Al technology maximizes the use of outstanding males by dissemination of superior genetic material, improve the rate and efficiency of genetic selection and introduction of new genetic material by import of semen rather than live animals. A large number of Als are performed globally; it is estimated that more than 100 million cattle, 40 million pigs, 3.3 million sheep and 0.5 million goats are artificially inseminated every year (Boa-Amponsem \& Minozzi, 2006; Verma et al., 2012). The first successful insemination was performed by Spallanzani (1784), on a bitch (Verma et al., 2012). It was through the success of Spallanzani where various aspects of $\mathrm{Al}$ technology have been globally standardized for each species. Smith (1988), introduced the concept of MOET and demonstrated how well designed MOET programmes could lead to increased selection intensity and reduced generation intervals, resulting in improving genetic gain (Chakravarthi et al., 2012). Genetic contribution of both male and female gametes can be used at the same through embryo transfer technology. Thus this improve livestock at a faster rate (Hafez, 2015). 
Moreover, data retrieved from the International Embryo Transfer Society committee report estimated the number of embryo transferred to be 800,000 in cattle, 25,000 in sheep, 7000 in goat, 30,000 in pig and 12,000 in horses worldwide with a conception rate of $55-70 \%$ (Hafez, 2015).

Embryo biotechnology is one of the powerful tools for animal breeders to improve genetic progress of their livestock herds $(\mathrm{Wu}, 2012)$. The objectives of genetic improvement of livestock include the acceleration of genetic progress often with the focus on a specific trait (Wu, 2012). Over the past three decades, embryo biotechnology has evolved through three stages: firstly, by superovulation which involves retrieval of embryo derived from donors and non-surgical recovery and transfer of cattle embryos, secondly, In vitro embryo production by in vitro fertilization by ovum pick up to retrieve oocytes and thirdly subsequent in vitro technologies, particularly cloning by somatic cell transfer, embryonic stem (ES) cell development, transgenic animal production and embryo transfer (Betteridge, 2004; Lonergan, 2007).

In vitro embryo production (IVEP) is one of the most crucial techniques amongst embryo biotechnologies used in farm animal breeding since it does not only help in production of high genetic merit animals, but also serves as an excellent source of embryos for emerging biotechnologies like embryo sexing, cloning, nuclear transfer and transgenesis (Duszewska et al., 2012; Hafez, 2015). Furthermore, it allows analyzing embryo development potential, including the pattern of gene expression, epigenetic modifications and cytogenetic disorders during the development (Galli \& Lazzari, 2008). The technology generally refers to a number of procedures performed in the laboratory which includes maturation, fertilization, and culture procedures required to produce embryos from immature oocytes (Duszewska et al., 2012). The first successful IVF was achieved on rabbits in 1959 (Chang, 1959), followed by mice in 1968, human in 1978 (Steptoe, 1980) and the first born calf produced with IVF was in 1981 (Brackett et al., 1982).

Handling of gametes in vitro however will always impose a threat to cells as they are under artificial conditions and will be easily damaged. The biological and practical reasons for damage might be the IVM Media compositions, in vitro handling in a dish, working conditions e.g. distance between oocyte donors or slaughter house and IVM laboratory, temperature variation and oxygen levels in the environment where embryos are handled (Callesen, 2012). However, the effect of the damage depends on the quality of the embryos or the techniques itself. Some embryos are more resistance to the stresses than 
others. It is therefore important to realize the extent of the damage and evaluate its importance (Brad et al., 2007; Callesen, 2012).

Gene expression patterns are one of the differences between in vitro produced embryos with the in vivo embryos in farm animal studies. In vitro embryos results in low expression of fundamental genes (Lonergan \& Fair, 2008; McHughes et al., 2009) due to cell apoptosis caused by its culture environment. Techniques are however available for morphological embryo quality evaluation such as total cell number determination by nucleus staining using propidium iodide (PI) or Hoechst (Pursel et al., 1985). However, in the South African laboratory systems, apoptotic assessment of embryos has not yet been evaluated. Apoptosis is defined by Fear \& Hansen (2011) as the "self-destruction of cells under physiological control". Apoptosis is one of the major aspects caused by imbalance of genes and culture environment of in vitro embryo production. It is characterized by cell shrinkage, translocation of phosphatidyl-serine to the outer cytoplasmic membrane, DNA fragmentation, and segmentation of the cell into apoptotic bodies (Elmore, 2007). Apoptosis is regulated by members of the Bcl-2 gene family such as the pro-apoptotic Bax and anti-apoptotic Bcl-2 and occurs through activation of caspases, a family of cysteine proteases. The activation of the Bcl-2, specifically the pro-apoptotic member genes is performed by the release of cytochrome $\mathrm{C}$ which interact with the apoptosis enzyme Apaf1 and therefore activate caspase 9 . The other activation of the anti-apoptotic member of the Bcl-2 gene is through the blocking apoptosis induced by the external stimulus (Ebrahimi et al., 2010) and when the the pro-apoptotic protein BAX is expressed it counteracts the apoptosis-preventing effect of BCL-2 (Somal et al., 2015).

Activation of these caspases releases DNAse enzymes that breaks the $3 \mathrm{OH}$ end of the DNA which later causes DNA fragmentation. This will then trigger the release of apoptotic initiator gene, the Bax gene. (Gjørret et al., 2003). The significance of evaluating the role of apoptosis caspases on in vitro embryos is an important initiative as this may lead to new methods for improving in vitro embryo production systems through selection of healthy embryos. It can be useful in developing molecular signatures to improve morphologybased embryo evaluation. This could further provide an understanding and aid in reducing embryonic mortality in female animals to improve implantation rates in cattle breeding. Moreover, there is no information on apoptosis evaluation of cattle in vitro embryo production in the South African context of beef cattle breeds. Therefore, assessment of apoptosis will aid in improving the efficiency of the IVEP prior evaluation and for better implantantation purposes. 


\subsection{Justification}

In South Africa, the use of reproductive technologies such as Al in beef cattle is most popular in stud cattle breeding, although Al is used on a limited scale in three-way crossbreeding systems to improve the management of the breeding program (van MarleKöster \& Webb, 2014). However, in vitro fertilization and embryo transfer in South Africa has been used more in wildlife compared to cattle breeding to breed disease-free buffalo and other scarce African ungulates such Roan and Sable antelope, due to the increasing monetary value of these species for the game and hunting industry (van Marle-Köster \& Webb, 2014). The use of IVF embryos by cattle breeders however has been steadily growing in South Africa over the years for building breed numbers and increasing genetic progress. During the past breeding seasons, production of embryos has increased from 2,858 in 2010, 5,028 in 2011 to 6,384 in 2012 through IVF (Invitrobrasil, 2016). The use of this technologies could lead in protein production needed by the estimated 9.5 billion growing population by 2050 (Thornton, 2010) in developing countries due to its potential of increasing the number of offspring per cow to up to 100 offspring in a year.

However, it has been documented that the in vitro culture (IVC) environment causes low expression levels of genes in cattle in vitro embryo production (IVEP). The IVC causes mitochondrial death, triggers stress activators that results in early embryonic loss due to cell apoptosis. This further leads to oocytes incompetence, chromosomal abnormalities and large offspring syndrome (LOS) (Farin et al., 2010). It is therefore important to evaluate the IVP system in terms of cell apoptosis for healthy embryo production in vitro.

\subsubsection{Aim of study}

The aim of the study was to evaluate the role of cell apoptosis on in vitro beef cattle embryos, with focus on oocyte maturation and embryo production, caspase activity and DNA fragmentation. The aim was achieved by the following objectives:

- To investigate the extrusion of polar bodies following four maturation temperatures: $39,41,42$ and $43^{\circ} \mathrm{C}$ on cattle oocytes, and subsequent in vitro embryo production from cattle oocytes matured at 39 and $41^{\circ} \mathrm{C}$.

- To investigate the caspase-3 activities on in vitro produced embryos following 39 and $41^{\circ} \mathrm{C}$ incubation temperature at different stages of cattle in vitro embryo production. 
- To investigate DNA degradation on in vitro embryos using tunel assay method from both 39 and $41^{\circ} \mathrm{C}$ incubation temperature at different stages of cattle in vitro embryos. 


\section{Chapter 2}

\section{Literature review}

\subsection{Introduction.}

In vitro embryo production (IVP) technology holds the potential to increase the number of offspring per cow to up to 100 offspring in a year. It can therefore contribute to a higher acceleration intensity in the herd and increase genetic progress (Suthar \& Shah, 2009; Vilarino \& Ross, 2015). In the beef cattle industry, IVP is used to develop new breed lines for increased selection, higher quality beef products or disease resistance and increase growth rate (Greger, 2010). Moreover, the use of IVP in the beef industry has been implemented largely by pure beef breeders ( $\mathrm{Wu}, 2012)$. However, the implementation of the technique poses a challenge world-wide to different reproduction specialists due to differences in the artificial environment of the growing embryos. The artificial embryo environment in most cases lead to apoptosis or cell death of the developing embryos. This chapter therefore focused on the review of available literature on in vitro embryo production technique, its effect, limitations, genetic regulations and apoptotic effects due to the in vitro environment of beef cattle embryos.

\subsection{Overview of in vitro embryo production in the beef cattle industry.}

The gestation period of a cow results in one offspring per year and thus tends to narrow the selection processes. However, assisted reproduction technologies (ART) can be used to improve selection and distribution of high genetic merit animals in the beef cattle industry (Kadarmideen et al., 2015). The ART procedures that can be applied to enhance reproduction in this industry are fertilization of oocytes either in vitro through collection of oocytes or in vivo through artificial insemination, embryo recovery through uterine flushing, in vitro embryo production and transfer of embryos to surrogates (Wu, 2012). In vitro embryo production through its processes such as oocytes maturation, fertilization and subsequent embryo production allows more frequent gametes collection and therefore further increase the number of transferable embryos (Plourde, 2012). Additionally, it has been mention that in vitro embryo production technique is estimated to yield three times more embryos than other ARTs through the constant collection of oocytes (Plourde, 2012). Retrieval of immature oocytes from cattle for initialising IVP can either be achieved from slaughter house ovaries or from a live donor cow. Ovum Pick Up (OPU) is one of the techniques used for retrieval of oocytes from a living donor in cattle. This technique was design for practical application where it was desirable to recover oocytes from living donors of known genetic value. However, according to Gallia et al. (2014), all the experimental work done to develop in vitro embryo production (IVP) procedures 
was essentially based on oocytes that were recovered from slaughter house ovaries in large numbers.

Since in vitro embryo production has been more successful as shown in figure 2.1, according to the International Embryo Transfer Society (IETS) statistics, the number of embryos produced in vitro and transferred into recipients has increased more than 10 times in the last decade and are now approaching the numbers of embryos produced in vivo by superovulation (Gallia et al., 2014; Mapletoft, 2015). This indicates that IVP is considered a reliable and costeffective technique and deserves a role in cattle breeding (Gallia et al., 2014). In vitro production of embryos is steadily growing and the majority of them are now produced by ovum pick up (OPU). The tremendous growth of IVP is shown on figure 2.1.

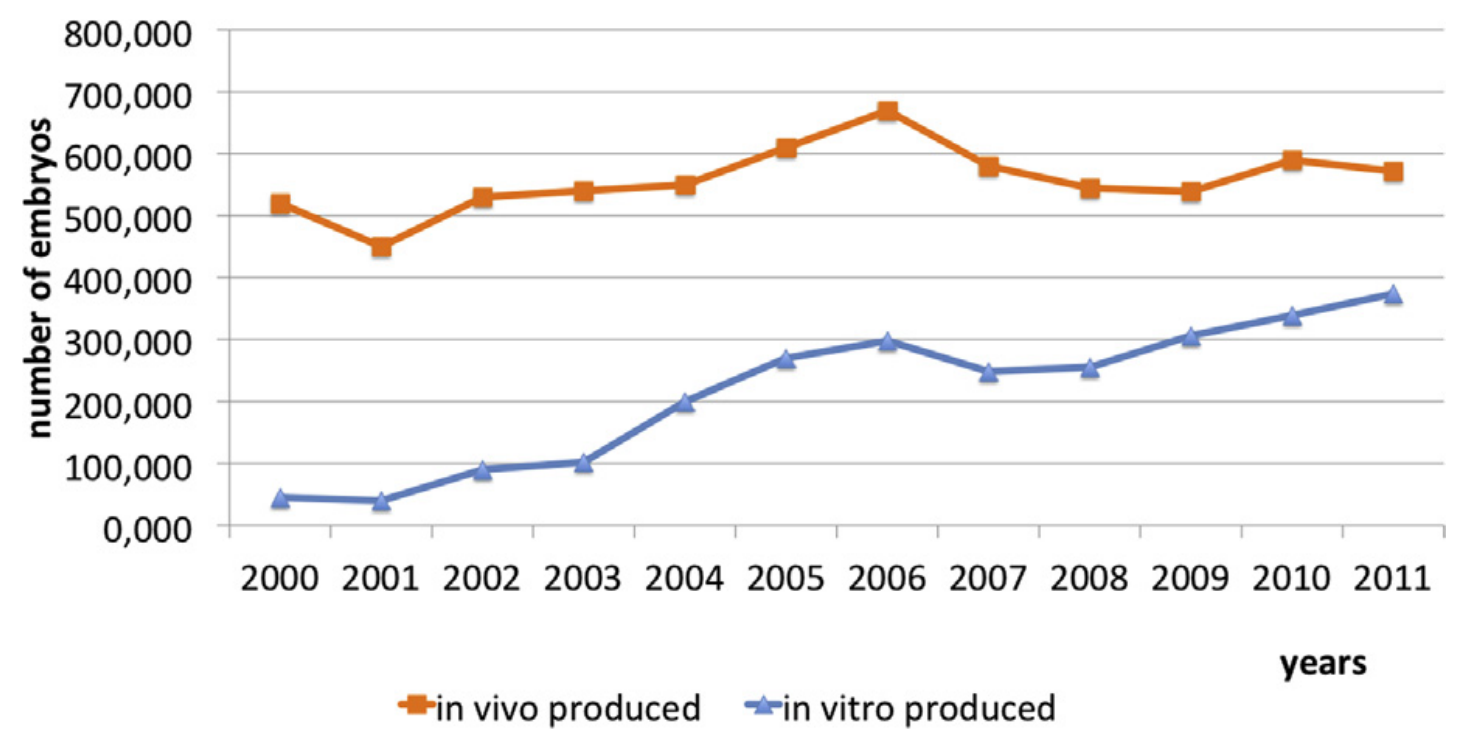

Figure 2. 1 Summary of the international Embryo Transfer Society stastistical data collected by the data retrieval committee (Gallia et al., 2014).

Authors, Pfeifer et al., (2008) and Machatkova et al., (2008), stated that IVP is an alternative that can be applied to accelerate genetic improvement via production of a larger number of embryos. This will therefore be vital for commercial usage, selection of high value donor cows, production of transgenic animals and embryo sexing. However, Paula-Lopes et al. (2012) and Hansen (2006) mentioned important technical limitations in IVP which collectively includes increased costs, sub-optimal embryonic, foetal survival and occasionally abnormal offspring known as large offspring syndrome. All above mentioned aspects are set to reduce the desirability of in vitro-produced embryos (Hansen, 2006). Plourde (2012), however, suggested that in vitro embryo system should be evaluated for an improved understanding of potential deviations. 


\section{Principles of in vitro embryo production}

The IVEP generally refers to a number of procedures performed in the laboratory that includes oocyte maturation, fertilization, and embryo culture steps required to produce embryos from immature oocytes (Blanco et al., 2011). The IVEP is set as an alternative to the in vivo embryo production by superovulation, also known as conventional embryo transfer (ET) (Viana et al., 2010). IVEP technique begins with: in vitro maturation (IVM) followed by in vitro fertilization (IVF) and in vitro culture (IVC). Maturation of mammalian oocytes as defined by Blanco et al. (2011), is the number of steps taking place from the germinal vesicle stage to completion of the second meiotic division with formation of the second polar body. IVM starts with retrieval of oocytes known scientifically as female germ cells either by OPU from a live animal or by retrieval from ovaries of a slaughtered animal. The oocytes are arrested at the early diplotene phase of meiotic prophase I. These cells are initially grouped within large, interconnected clusters known as oocytes nests. During the meiotic arrest of an oocytes the primordial follicles assembles, thus the processes is known as follicular assembles. Moreover, There's recruitment of primordial follicles into a growing cohort identified as primary follicles. Both processes define the earliest stages of folliculogenesis and are believed to affect the period of the female reproductive life span (Skinner, 2005; Picton et al., 2008).

Folliculogeneis is known to be one of the important procedures on the release of quality oocytes. The early events of production of oocytes is mostly regulated by steroid hormones that are predominant in ovarian biology such as progesterone, estrogen and androgen. Proper activating of folliculogenesis allows the growth of primordial follicles. During improper activation of follicologenesis other primordial follicles remain dominant for some time depending on the type of specie and this can therefore delay the maturity of the oocyte (Skinner, 2005). Reproductive disorders such as large offspring syndrome can intervene on proper follicular transition in cattle and sheep. Proper activation of folliculogenesis is important as it determines nuclear and cytoplasm maturation of the oocyte (Sirard, 2001). Furthermore, it's only a good quality oocyte that can be able to sustain embryo development prior transfer (Brevini-Gandolfi \& Gandolfi, 2001).

Once oocytes are matured, it is critical to introduce the oocytes to sperm that have already been capacitated or are undergoing capacitation for fertilization. Capacitated sperm usually refers to biochemical modifications that allow the acrosome reaction upon exposure to the zona pellucida, cumulus cells, or other substances associated with in vitro-matured or ovulated oocytes (John \& Parrish, 2013), the process therefore is referred to in vitro fertilization. The last stage IVP is known as in vitro culture. That is the development of the 
embryos from zygote to the morula and blastocyst stages (Duszewska et al., 2012). According to different authors (Lonergan \& Fair, 2008; Paramio, 2010; Dang-Nguyen et al., 2011), this encompasses nuclear and cytoplasmic modifications and their mutual interactions. Moreover, it further refers to changes in embryo metabolism, embryonic genome activation, modifications of gene expression, formation of the morula and compaction of blastomeres. It also formation of the blastocyst with a characteristic structure named the blastocyst cavity that arises as a result of cavitation, and formation of additional structures such as the capsule in the horse embryos.

The expression pattern of specific genes according to Wrenzycki et al. (2004), can aid in identifying molecular marker during immature oocyte and during the pre-implantation period. This will aid in identifying the molecular loophole in IVP. One of the factors that can affect the success of the in vitro system is apoptosis and large offspring syndrome (LOS) (Hill, 2014) and apoptosis (Yang \& Rajamahendran, 2002). There are however studies that provides information of gene expression on genes such as Cx43, HSP, G6PH, Oct-4, HPRT and GLUT1 during oocytes maturation and embryo development (Dalbies- Tran \& Mermillod, 2003), however, the expression of these genes can undergo changes and its effect on the expression changes is still unknown (Lonergan et al.,2003a).

The micro-environment of in vitro embryos production requires maintenance at all times for the success of embryo development (Rivera et al., 2004a; Jin et al., 2007). Factors such as heat or cold shock are common in disrupting the success of embryos development and survival prior transfer in artificial environment of in vitro embryos (Edwards \& Hansen, 1997; \& Wan et al., 2015). Furthermore, in vitro embryo needs to adjust to its own physiology in order to survive external stresses or it must have the ability to use the maternal information to restore its favourable micro-environment. According to Al-Katanani et al. (2002), production of heat shock protein can assist the embryos to adjust to its own physiological environment during external stress for survival (Al-Katanani et al., 2002). The quality of embryos depends on the correct amount and time of expression of fundamental genes during oocytes maturation, fertilization, first cleavage and embryo genome activation (Hansen, 2009). Therefore, the genetic information received from maternal (oocyte) and paternal (sperm) is set to be the first most crucial step to determines the quality of the embryo during embryo production (Hwang et al., 2010).

\section{Environmental factors influencing in vitro embryo production}

Several negative impacts have been reported for IEVP that can be attributed to its artificial micro-environment (Côté et al., 2011). Oxidative stress during the past decade has also been 
identified to affect the artificial micro-environment of embryo production resulting in either apoptosis or abnormal embryonic development. Furthermore, stress can impair mitochondrial integrity and its activity. Oxidative stress occurs as a result of an imbalance between antioxidants and reactive oxygen species (ROS) production. During in vitro culture of embryos, endogenous and exogenous factors are known to induce oxidative stress and temper with the balance of antioxidants. Moreover, the ideal oxygen tension for embryo culture is $5 \%$ (Yuan, 2003; Laura et al., 2007). Decrease ROS production and improved embryo metabolism tend to be associated with low oxygen levels in embryo production, thus this increase embryo production. (Ahmed et al., 2012).

The micro-environment in which the oocyte grows and mature defines its viability. Following oxidative stress, the most common environmental determinant in IVP of oocyte viability is heat stress. Heat stress alters secretion of hormones such as LH (luieternizing hormone), FSH (follicular stimulating hormone) and inhibin involved in follicular function. According to Paulalopes \& Hansen (2002), heat stressed oocytes reduce the ability for fertilization and therefore compromises the developmental stages of the embryos, either from fertilized or chemically activation.

Moreover, it is evident that heat stress affects growth of the follicles 30-40 days before oestrus during experiments evaluating damage by heat stress on follicular and oocyte function (Brad et al., 2007 and Paula-Lopes et al., 2012). The oocyte remains susceptible to heat stress damage until nuclear and the cytoplasmic maturation is completed (Ju et al., 2005). According to Hansen (2009), heat stress causes a reduction in the proportion of oocytes that can become normal embryos later in development when applied $10 \mathrm{~h}$ beginning of oestrus. During maturation of oocytes, heat shock further induces disruption in chromosome alignment, decrease the ability of the oocyte to reach metaphase II. Therefore, the environment in which is ideal for IVP is of most important as it determines the future produced embryo.

\subsection{Genetic regulation and action of in vitro embryo production.}

The production of embryos in vitro firstly depends on the production of maternal RNA and synthesis of proteins for the maintenance of the oocyte before fertilization. The mRNA synthesises proteins for embryo survival until the 4 cell stage in cattle (Badr et al., 2007). Furthermore, as production proceeds prior the 4 cell stage, RNA and proteins degenerate and the embryo will then depend on the newly gene transcript (Memili \& First, 2000). In embryo development this is characterized as minor bovine embryonic genome activation, and is the 
process by which the embryo development depend on its maternal transcript for survival until the activation of major embryonic genome starts, which occurs at the 8 cell embryonic stage (Graf et al., 2014). In cattle, the zygotes and embryos become transcriptionally and translationally active between 1 cell to 4 cell stages. The process by which the first transcripts are active prior 4 cell stage in cattle is called minor genome activation (Barnes \& Eyestone, 1990; Jiang et al., 2014). In oocyte maturation and early embryo cleavage (1-4 cell), the maternal transcripts and proteins synthesised are used to sustain the embryo until major genome transcripts are produced (Dieleman et al., 2002; Lee et al., 2014). The maternal mRNAs after fertilization, prior to first cleavage, supports the successful initialization of embryonic genome activation (EGA) (Kan`ka, 2009).

Once the mRNA has degenerated, the embryo is ready to switch from maternal to depend on the embryo transcript for survival, therefore fundamental genes will be produced. The RNA and the proteins from the maternal cease due to the presence of transcriptional inhibitors and marked changes in the pattern of the protein synthesis. This process is known as maternalembryonic transition (Telford et al., 1990; Lee et al., 2014). The maternal-embryonic transition in cattle occurs during the time which the embryo depends on embryonic genome at 8-16 stage. These suggest that the mRNA will be transcript from embryo genome and the pattern of the protein synthesis will change to accommodate the new life of the embryo (Memili \& First, 2000).

The maternal to embryonic genome transition is pre-requisite for the activation of a large number of genes and for patterns of expression of genes responsible for successful embryonic differentiation and development (Lequarre et al., 2003; Lonergan et al., 2003a). Furthermore, the pattern of the mRNA of genes from embryo genome regulating embryo development can be useful for molecular markers during the pre-implantation period (Wrenzycki et al., 2004; Rodriguez-Alvarez et al., 2010). The mRNA expression pattern of genes regulating embryo development is regarded as one of the relevant parameter determining embryo quality (Wrenzycki et al., 1999; Farin et al., 2004; Dode et al., 2006). Moreover, abnormalities that can results in failure of the embryo development and thus compromise the survivability of the embryo before and after cryopreservation, transfer and implantation can occur through the alteration of the mRNA expression. (Niemann \& Wrenzycki, 2000; Yang \& Rajamahendran, 2002; Wrenzycki et al., 2004). Analysis of transcript related to embryo quality by means of gene expression technique has become the most powerful tool for determining embryo quality (Warzych et al., 2007). In embryo development, the expression of genes such as Connexin 43 (Cx43), Glut-1, the housekeeping X-linked gene glucose-6-phosphate dehydrogenase (G6PD) and HPRT (Hypoxanthine-guanine phosphoribosyltransferase) are amongst those 
genes responsible for physiological functions that assist in the development of embryo prior transfer (Table 2.1).

Table 2. 1 List of gene transcript in cattle oocytes and embryos related to their function throughout prei-mplatation development.

\begin{tabular}{|c|c|c|}
\hline Genes & Function & Reference \\
\hline Cx43(Connexin 43) & $\begin{array}{l}\text { Regulate the exchange of small metabolites } \\
\text { and ions (up to } 1 \mathrm{kDa} \text { ) between adjacent cells } \\
\text { and thereby coordinate metabolic and } \\
\text { electrical activities. } \\
\text { Gap junctions are thought to play a crucial } \\
\text { role in regulating cell growth and } \\
\text { development in cattle embryos. }\end{array}$ & Wrenzycki, et al., 1996 \\
\hline Glut-1 (glucose transporter-1) & $\begin{array}{l}\text { Glucose transporter, Basal glucose uptake; } \\
\text { transport across blood-tissue barriers }\end{array}$ & ( Lee, 2001) \\
\hline Hsp70(heat shock protein 70) & $\begin{array}{l}\text { Refolds and maintains denatured proteins in } \\
\text { vitro }\end{array}$ & \\
\hline $\begin{array}{l}\text { G6PH(glucose-6-phosphate } \\
\text { dehydrogenase) }\end{array}$ & $\begin{array}{l}\text { Candidate for involvement in sex } \\
\text { differences, An important role of the enzyme }\end{array}$ & (Jolly et al., 2000) \\
\hline $\begin{array}{l}\text { HPRT(Hypoxanthine- } \\
\text { guanine } \\
\text { phosphoribosyltransferase) }\end{array}$ & is to detoxify oxygen radicals & \\
\hline $\begin{array}{l}\text { Insulin growth factors } \\
\text { (IGF,IGF-IIR and IGF-1) }\end{array}$ & $\begin{array}{l}\text { Embryonic growth factors with pleiotropic } \\
\text { mitogenic activity. }\end{array}$ & (Wrenzycki, et al., 2002a). \\
\hline $\begin{array}{l}\text { OCT-4(octamer-binding } \\
\text { transcription factor), }\end{array}$ & Transcription factor initiating transcription. & (Wrenzycki et al., 2005 \\
\hline BAX & Pro apoptotic regulator & (Wrenzycki et al., 2005 \\
\hline $\mathrm{Bcl}-\mathrm{xl}$ & $\begin{array}{l}\text { Anti-apoptotic regulator, inhibitor of apoptotic } \\
\text { proteins. }\end{array}$ & (Jolly et al., 2000) \\
\hline polyAtail & MRNA processing & (Wrenzycki, et al., 2002b). \\
\hline
\end{tabular}

Expression patterns of genes has the ability to become markers for embryo quality because it is useful for important biological processes such as compaction, metabolism, transcription and 
translation, DNA methylation, growth factor/cytokine signalling, cell cycle regulation during pre-implantation and post implantation stages, (Wrenzycki et al., 2004).

Genes in embryo life are expressed differently at different stages and show two expression pattern: the first expression pattern starts at 8-16 cell after embryonic genome activation and the embryo at the time depends completely on embryonic activity. The second starts just before and after embryonic genome activation. At this stage the embryo depend on the maternal and embryo transcriptional pattern (Niemann \& Wrenzycki, 2000). Genes expressed during pre-implantation of the embryos are involved in different stages of embryo development and growth (Silva et al.,2013). Moreover, characterization of these genes will identified those that are altered during abnormal development. For proper development in embryos, there must be a relationship between the phenotype and gene expression profile this ensures clinical effect of the changes and clarifies the expression pattern of genes necessary for preimplantation growth (Ponsuksili et al., 2002). Therefore, for this reason, identification of preimplantation genes on cattle embryos would provide information towards the success of embryo production and evaluating the existing protocols to more suitable conditions for preimplantation and post-implantation developments. In Table 2.2 and 2.3 the different genes involved in different pre-implantation stages on an embryo are illustrated.

Table 2. 2 Illustration of oocyte growth and gene indication genes associated with each developmental stage (Wrenzycki et al., 2005).

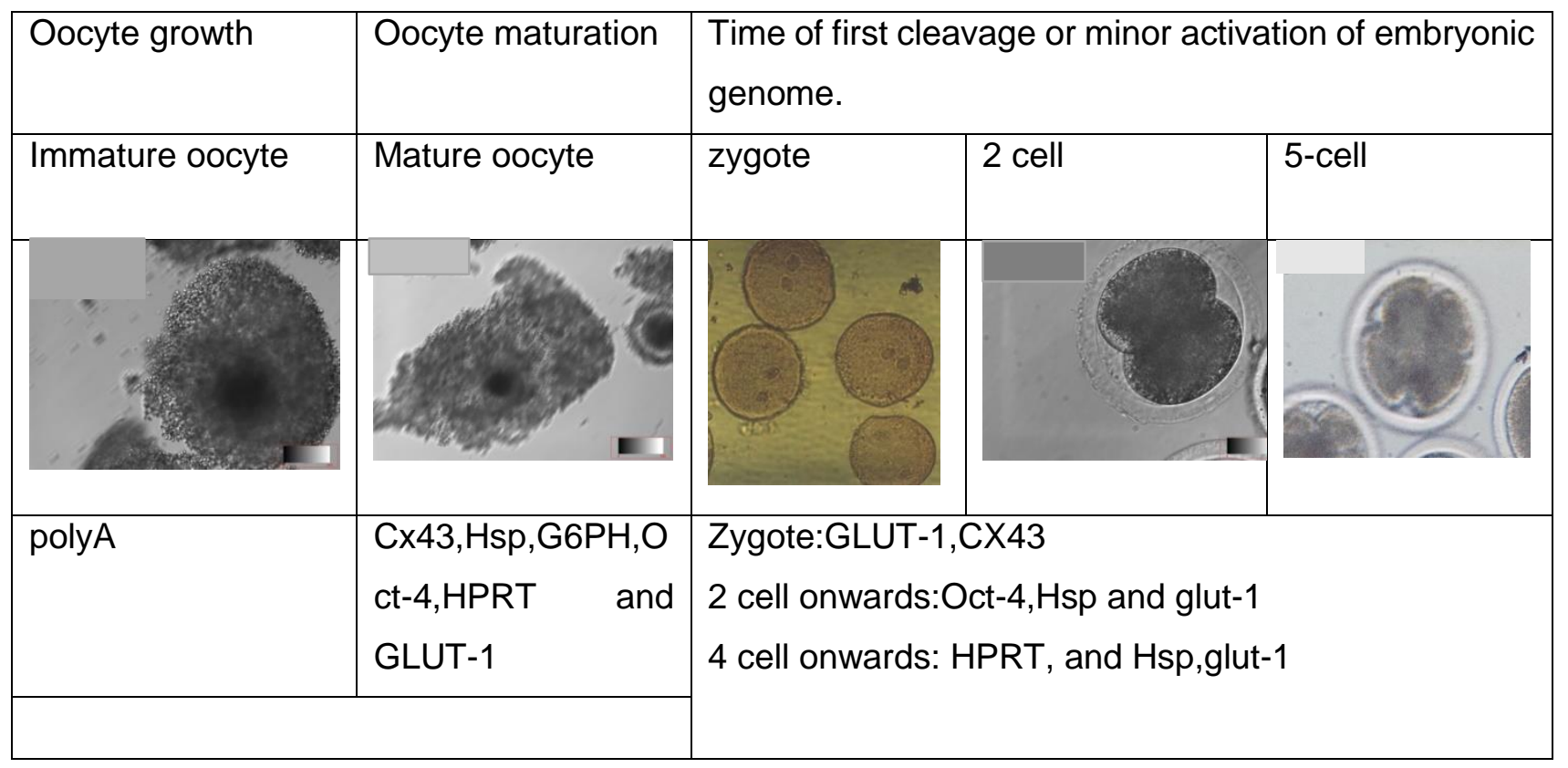


Table 2. 3 Expressed transcript after the major activation of embryonic genome (Wrenzycki et al., 2005)

\begin{tabular}{|l|l|l|}
\hline \multicolumn{2}{|l|}{ Expressed transcript after the major activation of embryonic genome } \\
\hline 8-16 cell & Morula & Blastocyst \\
\hline & & \\
& & \\
\hline
\end{tabular}

Different genes are expressed differently in different in vitro culture mediums with different supplementations (Silva et al., 2013). The connexin 43 gene is not detected in medium supplemented with serum but it is unregulated in the medium supplemented with polyvinyl alcohol. Glucose transporter 1 gene is standard in serum supplemented medium and up regulated in polyvinyl alcohol supplementation medium (Watson et al., 2000). However, heat shock protein is unregulated in serum and standard in polyvinyl alcohol. It is therefore clear that among various IVM media and chemical supplementation, mRNA expression pattern can differ (Watson et al., 2000). The expression of genes in different supplementation mediums do not show differences in gene expression patterns. However, the period of post fertilization culture environment can have a significant impact on mRNA abundance (Lonergan et al., 2003b). Moreover, the survival of an embryo in a specific culture system can be done by monitoring the levels of mRNA and this could an indirect way of quality assessment in the embryo (Liu et al., 1997 \& Park et al.,2006). This further generate information on expression patterns used as genetic markers and gives an indication of abnormal embryo during their preimplantation stages. In a transcriptome experiment using a bovine-specific microarray, 26 genes were down-regulated in cattle embryos between Day-7 blastocysts and Day-14 conceptus, while more than 500 genes were up-regulated and most of them continued to be expressed until the time of implantation (Rodriguez-Alvarez et al., 2010). Table 2.4, summarize the differences in the relative abundance of gene transcripts in cattle embryos grown in culture medium (T-199) with different supplements (Wrenzycki et al., 1999). 
Table 2. 4, Difference in gene transcripts on bovine embryos produced in culture medium (T199) with different supplements

\begin{tabular}{|c|c|c|c|}
\hline Transcript & serum & Polyvinyl achol & Embryonic stages \\
\hline Connexin43 & - & $\uparrow$ & $\begin{array}{l}\text { 8-16 cell. morula., } \\
\text { blastocyct. }\end{array}$ \\
\hline $\begin{array}{l}\text { Glucose transporter- } \\
1\end{array}$ & + & $\uparrow$ & 8-16 cell. \\
\hline $\begin{array}{l}\text { Heat shock protein } \\
70\end{array}$ & $\uparrow$ & + & $\begin{array}{l}\text { Oocyte maturation- } \\
\text { morula. }\end{array}$ \\
\hline Poly $(A)$ polymerase & + & $\uparrow$ & Maturation, 8-16 cells. \\
\hline
\end{tabular}

\section{Genetic factors influencing in vitro embryo production.}

Embryo development can be affected by various factors resulting in cleavage and gene transcript to cease (Betts \& Madan, 2008). Moreover, in embryo production, most of the embryo block that can affect development occurs mostly between the fourth and fifth cell cycle transition (Memili \& First, 2000). The embryonic development block occurs simultaneously with the maternal embryonic transition and embryos that cannot produce their own embryonic genome transcription die due to this block. The developmental block can be caused by two main mechanisms namely: inability to overcome the chromatin repression and activate transcription of important developmental genes and injury reaction caused by environment (Betts \& King, 2001).

\section{Effect of glucose in cattle embryo production system}

In mammalian cells, glucose is one of the main source of energy with the glucose transporter as primary entrance for uptake of glucose in mammalian cells. Glucose transporters (GLUTs) are glycoproteins encoded by a family of SLC2A (Trehalose inhibits solute carrier 2A) genes. The SLC2A genes are responsible for the uptake of several monosaccharides including glucose, fructose, mannose, galactose and glucosamine (Das, 2012). Transcription of genes such as glucose transport-1 and HSP70 play a fundamental role in the embryo production and when their transcriptions are altered they can cause embryonic cell death. The expression level of genes related with embryo metabolism such as the glucose transporters Glut-1 and 
Glut-3 as well as genes from the insulin-like growth factors system (IGF2, and receptors IGF$1 \mathrm{r},-2 \mathrm{r})$ also changes during cattle embryo elongation.

\section{Heat stress in bovine in vitro embryos.}

Ritossa in 1862 was the first to discover heat shock response after identifying puffs of Drosophila salivary gland chromosomes due to temporary heat shock exposure. During activation of embryonic genome both mouse and cattle embryos become resistant to heat shock exposure, that is 1-2 cell stage in mouse and from 8-16 stage in cattle (Jolly et al., 2000). Exposure of cell to mild heat shock activates thermotolarance and therefore the thermotolarance effect can assist the cell to become more resistance to severe heat shock. These phenomena can be identified in cattle blastocyst but not in earlier stages of embryos (Mortensen et al., 2010).

In cattle embryos, the cleavage stage become more susceptible to damage by heat stress (Badr et al., 2007). Moderate heat exposure on pre-implantation developmental stages of embryos can cause more damage and cease development. This was observed in Rivera et al. (2003) whereby exposure of mouse embryo development to $39^{\circ} \mathrm{C}$ at 1 cell was inhibited while in cattle, the developmental embryo was decreased when exposed to $41{ }^{\circ} \mathrm{C}$ at 4 hours. Embryos after 2-4 stage cell when they approach subsequent development their hypersensitivity towards heat stress become reduced in the culture environment (Silva et al., 2013). One of the major cause of mortality in embryo production on different species such as cattle, rabbit and sheep is susceptibility to heat stress (Rivera et al., 2003). However, the cell can be able to act against the elevated temperatures through the cell- protective processes such as the cytoprotection or thermotolarance. Moreover, the cell can induce the expression of HSP genes that protect the cell from thermal challenges in further developmental processes of the cell. There's differences in production between in vitro and in vivo embryos. The in vitro embryo can increase lipid content in the cell, exhibit retarded development rate or lower the survivability after freezing (Hansen, 2009).

In animal reproduction, in vitro embryo production is considered as one of the most suitable model to study the mechanism influence of high temperature. These is because of the production processes of producing embryos in vitro, such as oocyte maturation, fertilization and subsequent embryo development (Duszewska et al., 2010) which allows the examination of the processes related to thermosensitivity and thermoresistance of gametes and embryos (Zeron et al., 2001; García-Isperito et al., 2007). Increasing the temperature of embryo culture 
from $40-41^{\circ} \mathrm{C}$ in most in vitro experiments is used to induced stress and most of the control temperature used ranges between 38 and $39^{\circ} \mathrm{C}$ (Rynkowska et al., 2011).

Roth \& Hansen (2005), demonstrated that, the disruption in oocytes maturation after thermal stress is due to the changes in karyokinesis. Most of the oocytes exposed to high temperature $\left(41^{\circ} \mathrm{C}\right)$ are arrested at the first meiotic metaphase. This may be due to the incorrect chromosomal segregation during anaphase caused by the activation of meiotic spindle check point when oocytes are exposed to elevated temperatures (Brunet et al., 2003). Meiotic spindle check point is activated when incorrect arrangement of chromosomes in metaphase plate or incorrect attachment of chromosome to the spindle is recognized, and consequently leads to anaphase delay (Zhou et al., 2002; Cleveland et al., 2003). Roth \& Hansen (2005), reported that heat stress in cattle oocytes also shows deformation of meiotic spindle, a decrease in the amount of actin connected to the membrane, and increase in amount of actin dispersed in the cytoplasm. The sensitivity of heat stress differs in different stages of embryo production. Oocytes, morula and blastocyst are less sensitive to heat stress compared to embryos at 2-4 cell stage (Rivera et al., 2004a). In 2-4 cell cattle embryo stage, they might be the production of free radicles due to the activity of the mitochondria which makes the embryos highly thermosensitive as a results of thermal stress (Hansen, 2007). According to Rivera et al.(2004b), the changes that occurs inside the blastomere that are considered to be impossible to overcome by genome activation at the 8 cell stage can also inhibit embryonic development by elevated temperature.

Elevated temperatures do not activate apoptotic signals in 2-4 cell stage and the first apoptotic cells do not appear until 8-16 cell stage in cattle and not earlier than 4 days post fertilization (Matwee et al., 2000; Paula-Lopes \& Hansen, 2002). According to Rynkowska et al. (2011), the above suggest that, activation of apoptosis depends on the number of mitotic division and the time past fertilization in pre-implantation of cattle embryos. This suggests that those embryos that have passed through the activation of embryonic genome are more resistant to elevated temperature because during these time embryos are already able to induce programmed cell death and it is possible to eliminate damaged cells from the embryo (Rynkowska et al., 2011).

One of the mechanisms that the oocytes and embryos protect themselves against damages from external factors including heat shock id through the production of heat shock protein 70 . The HSP 70 is an important element of thermoresistance in cattle gametes and function both in the cytoplasm and the nucleus. These proteins can recognise incorrect folding of other proteins and assist in them to fold correctly (Rynkowska et al., 2011). They can also assist 
newly synthesized proteins during their folding. In other cases, they can newly synthesis other proteins and select dysfunctional proteins and direct their discharge to their degradation site (Rynkowska et al., 2011). Moreover, HSP 70 protects cells from heat shock by stabilizing ribosomal RNA (Duncan \& Hershey, 1989; Nover \& Scharf, 1991). Hendrey \& Kola (1991), concluded that for successful embryonic production oocytes became more resistant to heat shock when microinjected with HSP 70.

\subsection{Cell apoptosis and $\mathrm{Bcl}-2$ protein family genes}

Apoptosis has been first discovered by Kerr et al. (1972) by identifying electron morphological analysis of a dying cell. It is a process dependent on morphologically and biochemically stimuli (Yang \& Rajamahendran, 2002). During apoptosis a condensed and misshapen nuclei with clumped chromatin smaller than intact healthy nuclei can be observed. A cell that shows signs of apoptosis tend to rounds up and separate from its neighbouring cells (Opiela, 2009).

Apoptosis in cattle consists of two pathways, the intrinsic apoptotic pathway that involves the mitochondria and an extrinsic apoptotic pathway that involves death receptors (Cleary et al., 1986; Melka et al., 2010). The mitochondrial pathway of apoptosis in mammals is regulated by members of the B cell lymphoma-2 (BCL-2) family of proteins (Melka et al., 2010). Bcl-2 family proteins are key regulators of the apoptotic process. The $\mathrm{Bcl}-2$ proto oncogene was originally identified from a human chromosomal translocation that predisposed affected individuals to malignant transformation of immune cells (Cleary et al., 1986).

In apoptosis the $\mathrm{Bcl}-2$ related genes are known to be regulatory genes in the apoptotic pathway (Hossini et al., 2005), this gene family may either suppress or promote the presence of apoptosis in mammalian embryos (Muscarella et al., 1998). In the mitochondria, the Bcl-2 proteins are the key regulators of the permeability of mitochondrial membrane. These proteins are divided into two groups: the pro-apoptotic which promotes apoptosis (Bcl-XS, Bid, Bax, Bak, Bik and Bad) and anti-apoptotic proteins (Bcl-W, Bcl-XL, Bcl-2, A1 and Mcl-1) that works to prevent cytochrome $C$ release to initiate apoptosis (Shamas-Din et al., 2013). In table 2.4 shows the locations of the bcl-2 family genes are shown. 
Table 2.5 Subcellular localization of BCL-2 family members as provided in genebank (Youle \& Strasser, 2008). http://www.ncbi.nlm.nih.gov/gene/ and http://www.ncbi.nlm.nih.gov/unists).

\begin{tabular}{|c|c|c|c|c|}
\hline $\begin{array}{l}\text { BCL-2 } \\
\text { family } \\
\text { member }\end{array}$ & Chromosome no & $\begin{array}{l}\text { ALIAS } \\
\text { ES }\end{array}$ & $\begin{array}{l}\text { Location in healthy } \\
\text { cells }\end{array}$ & $\begin{array}{l}\text { Location in } \\
\text { apoptotic cells }\end{array}$ \\
\hline \multicolumn{5}{|c|}{ Anti-apoptotic members } \\
\hline BCL-2 & $\begin{array}{l}\text { Chromosome 5, } \\
\text { AC_000162.1 } \\
\text { (98196412..98233 } \\
\text { 551, complement) }\end{array}$ & $\begin{array}{l}\text { BOS } \\
5853\end{array}$ & Mitochondria and ER & $\begin{array}{l}\text { Mitochondria } \\
\text { and ER }\end{array}$ \\
\hline BCL-XL & $\begin{array}{l}\text { Chromosome13, } \\
\text { AC_000170.1 } \\
\text { (61766800..61817 } \\
\text { 390, complement) }\end{array}$ & $\begin{array}{l}\text { BOS } \\
13290 \\
\text { BCLX, } \\
\text { Bcl-xL }\end{array}$ & $\begin{array}{l}\text { Cytosol, mitochondria } \\
\text { and ER }\end{array}$ & $\begin{array}{l}\text { Mitochondria } \\
\text { and ER }\end{array}$ \\
\hline BCL-W & $\begin{array}{l}\text { Chromosome 23, } \\
\text { AC_000180.1 } \\
\text { (7654652..766191 } \\
5, \text { complement })\end{array}$ & $\begin{array}{l}\text { BOS } \\
21299\end{array}$ & $\begin{array}{l}\text { Cytosol and } \\
\text { mitochondria }\end{array}$ & Mitochondria \\
\hline MCL1 & $\begin{array}{l}\text { Chromosome 3, } \\
\text { AC_000160.1 } \\
(20172164 . .20176 \\
968)\end{array}$ & $\begin{array}{l}\text { BOS } \\
2960\end{array}$ & $\begin{array}{l}\text { Cytosol, mitochondria } \\
\text { and } \\
\text { ER }\end{array}$ & Mitochondria \\
\hline \multicolumn{5}{|c|}{ Pro-apoptotic members } \\
\hline BAX & $\begin{array}{l}\text { Chromosome 18, } \\
\text { AC_000175.1 } \\
(55985166 . .55989 \\
379)\end{array}$ & $\begin{array}{l}\text { BOS } \\
17596\end{array}$ & $\begin{array}{l}\text { Mainly cytosolic, } \\
\text { although in cultured } \\
\text { cells, up to } 50 \% \text { of } \\
\text { the BAX can attach } \\
\text { lightly to the } \\
\text { mitochondria }\end{array}$ & $\begin{array}{l}\text { Mitochondria } \\
\text { and ER }\end{array}$ \\
\hline BOK & $\begin{array}{l}\text { Chromosome 5, } \\
\text { AC_000162.1 } \\
(114542464 . .1145 \\
71825)\end{array}$ & $\begin{array}{l}\text { BOS } \\
6166\end{array}$ & $\begin{array}{l}\text { Cytosol and } \\
\text { mitochondria }\end{array}$ & Mitochondria \\
\hline BID & $\begin{array}{l}\text { Chromosome 29, } \\
\text { AC_000186.1 } \\
\text { (43190195..43202 } \\
349, \text { complement) }\end{array}$ & $\begin{array}{l}\text { BOS } \\
24844\end{array}$ & Cytosol & $\begin{array}{l}\text { Cytosol and } \\
\text { mitochondria }\end{array}$ \\
\hline
\end{tabular}

At the time of stress or damage in the cell, the pro-apoptotic members of the Bcl-2 family proteins such as Bax or Bak will be activated at the mitochondria. Activation of these proteins results in the formation of pores outside the mitochondrial membrane which then lead to the escape of pro-apoptotic molecules, including caspase and cytochrome $C$. The release of mitochondria-derived activator cytochrome $C$ will then activate the release of members of the 
proteases called the caspases that cleave the key cellular proteins to initiate death (Brunelle \& Letai, 2009).

\section{The Bcl-2 family member genes in cattle pre-implantation embryo}

Apoptosis can be primarily identified in cattle embryo morphology. During the pre-implantation stage of the embryo, a number of stimulus can cause the cell to enter its apoptotic phase through the interference of the balance between the pro- and anti-apoptotic proteins which identifies either susceptibility or resistance to apoptosis (Johansson et al., 2010). Once the embryo cell enters its apoptotic phase, the cascade of caspases is activated and it cleaves the specific downstream target and cause a number of irreversible damages such as organelle dysfunction, membrane blebbing, cytoplasm shrinkage, cellular degradation, formation of apoptotic bodies and condensation of nuclear chromatin (Jolly et al., 2000).

During oocyte and embryo development, different members of the Bcl-2 protein family are expressed differently (Boumela et al., 2009). Amongst the pro-apoptotic members, the Bax is the most dominant member in oocytes and embryo under stressful conditions. Furthermore, Melka et al. (2010), reported that the expression of the Bax to the oocytes and embryo in cattle suggest that the pre-implantation development may be under permanent threat of death. These will then mean that the survival of the embryo will depend on the inhibition of its proapoptotic activity and the release of the anti-apoptotic member the Bcl-2 gene. Furthermore, the high expression levels of $\mathrm{Bcl}-2$ expression suggest that the embryo may have a chance to supress the expression of Bax activity (Boumela et al., 2011).

The apoptosis pathway in mammalian cells including cattle embryos start at the activation of the pro-apoptotic members of the bcl-2 family such as Bax, Bid or Bad to the mitochondria. However, each pro-apoptotic member works at specific settings for the initiating apoptosis (Wilfling et al., 2012). For example, Zimmermann et al. (2001), revealed that Bax is responsible in DNA fragmentation apoptosis, Bid initiate Fas-mediated apoptosis and Bad is activated in neurotrophin deprivation-induced death. The activation of these pro-apoptotic proteins will release the cytochrome $C$ protein contained within the intermembrane space of the mitochondrion (Wilfling et al., 2012) The cytochrome $C$ in the mitochondria will then be couples with a heme group to became holocytochrome $c$. It is in this form that the cytochrome C can induces caspase activity (Yang et al., 1997). The caspases are a family of the cysteine proteases and they initiate the phases of apoptosis (Brad et al., 2007). Apoptosis is initiated by caspases through cleavage DNAse 1 enzyme within the caspase and this enzyme 
mediates biochemical and mophologcal changes such as DNA fragmentation and plasm membrane blebbing (Ko"hler, 2002).

Once the caspase is released through the formation of apoptosome which is the combination of cytochrome c, apoptosis protease activating factor-1(Apaf-1) and procaspase 9, the cell will officially undergo apoptosis (Zimmermann et al., 2001). Apaf-1 is an apoptotic protein that reside within the cytosol in the mitochondria and when it binds to the cytochrome $C$ it induces it to oligomerize. It consequently activates Pro-caspase 9, which then causes the apoptosome to recruit pro-caspase-3. Pro-caspase 3 will then be released to mediate apoptosis as shown in figure 2.2.

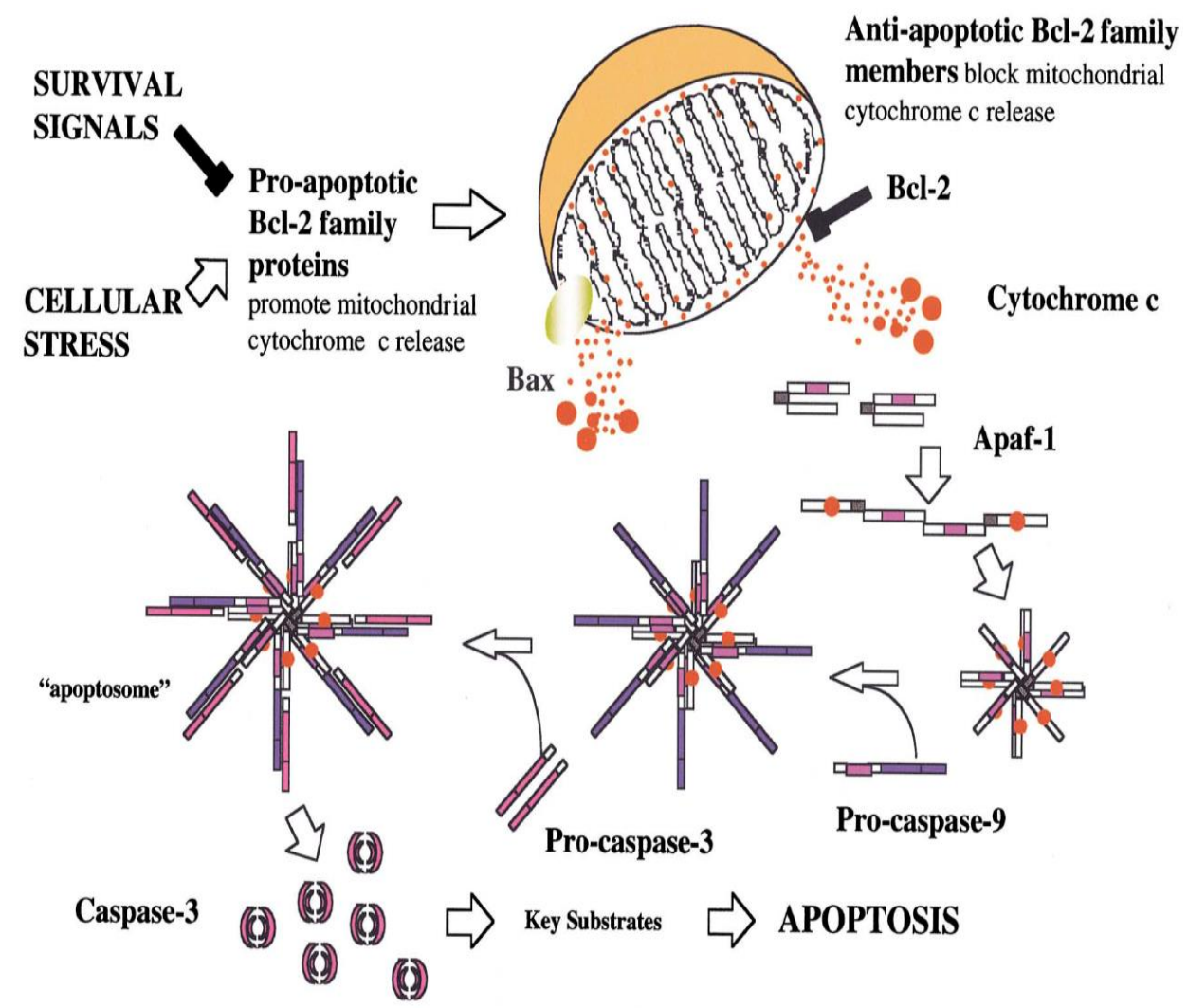

Figure 2. 2 . Induction of apoptosis in the mammalian cell via the mitochondrial pathway (Zimmermann et al., 2001)

According to Zaraza et al. (2009), apoptosis in cattle embryos is observed when embryo genome is activated at 8 cell stage of development. Poor development of embryos in cattle as a result of external stimulus is often associated with apoptosis and this lead to the death of the embryo prior compaction (Zaraza et al., 2009). However, the is no discovery of apoptosis incidences either morphologically, biochemically or molecular in cattle embryo prior the 8 cell stage (Byrne et al., 1999; Matwee et al., 2000; Gjørret et al., 2003, Betts \& Madan 2008). Conversely, several reporters (Matwee et al., 2000; Brad et al., 2007\& Gjørret et al., 2007) emphasised that even though the 2-4 cell stage embryos can be under apoptosis attack due 
to mitochondrial depolarization or inhibition of protein kinases, apoptosis will be partially activated and the embryo will exhibit some caspase activity and have limited DNA fragmentation. The above suggest that embryos at 2-4 cell can have all the apoptotic machinery due to stimulus however they are not affect mainly due to the immature mitochondria and they might be non-ascertained factors that assist them to overcome some inhibition of apoptosis pathway (Weil et al., 1996; Brad et al., 2007; Bakri et al., 2016).

\section{Factors influencing apoptosis in cattle embryos.}

The stimulus for apoptosis in cattle embryos can be within the embryo cell such as excess production of oxidative species and DNA damage or extracellular such heat stress (Vandaele et al., 2008). The damage that is due to DNA fragmentation on the embryo cell can be shown by excess increase in the expression of the transcription factor, the tumour protein 53 (TP53) to most pro-apoptotic gene (Betts \& King 2001). Moreover, according to Yu (2015), the caspase-associated DNase (CAD) which is a magnesium-dependent endonuclease specific for cutting dsDNA to generate 3-hydroxy ends, is a bench mark of apoptosis. The Bcl-2 expression, however, during the growth of an embryo specifically at the blastocyst stage appears to be restricted to specific cells of the inner mass, whereas Bax has been shown to be localized in the cytoplasm of the blastomeres which are the trophectoderm cells and the inner cell mass (Viuff et al., 2001; Vandaele et al., 2008).

The artificial environment of the in vitro embryo production processes such as IVM, IVF and IVC can influence apoptosis. During the in vitro processes, cellular stresses, imbalance of nutrients and chromosomal abnormalities can occur and these therefore activate the presence of apoptosis to the growing embryos and affects its ability to reach the blastocyst stage (Viuff et al., 2001 \& Knijn, 2004). The activation of embryo genome plays a vital role in apoptosis activation because improper activation of these process can trigger the release of apoptosis factors in cattle. This is evidence of the detection of apoptosis from the 6-8 cell stages in cattle and less detection at the earlier stage before embryo genome activation (Byrne et al., 1999; Gjørret et al., 2003). During the summer season the higher outside temperature affect embryo production processes (oocyte maturation, fertilization and embryo development) in vivo embryo production which can leads to apoptosis (Rynkowska et al., 2011). Moreover, apart from all inducers of apoptosis, heat stress is one of the main factor that triggers embryo apoptosis (Hansen, 2009). It is therefore suggested that for the success of the in vitro embryo production, a balance of pro and anti-apoptotic proteins is important (Matwee et al.,2000; Yang

\& Rajamahendran, 2002) 
In the study by Roth \& Hansen (2005) it was emphasized that in all the process of embryo production, it is the nuclear maturation of oocytes that is most affected by high temperature and results in disruption of the nuclear. Dorado et al. (2001), consider that it affects mainly cytoplasmic maturation. high temperature affects the joining of the maternal and the paternal and therefore delay the first mitotic division of the zygote because of the disruption of the cytoskeleton (Rivera \& Hansen, 2001). In the case of high temperature, it is not only the division of the zygote that is affected but also the potential of the zygote to develop further and become an embryo. Moreover, the affected embryo can have suppression of the expression of fundamental gene abnormalities in the embryo and cell death (Rivera \& Hansen, 2001).

The apoptotic cells in mammalians can be seen by the presence of fragmentated DNA, shrinkage of the cell and segmentation of the cell into apoptotic bodies (Opiela, 2009). DNA fragmentation can have severe cellular consequences and it is divided into two categories namely the lesion and strand breaks. The lesion DNA fragmentation damage can cease the transcription and replication processes in the DNA, these therefore results in the production of mutation due to changes in the chemical and physical structure of the DNA (Doherty \& Jackson, 2001; Sturmey et al., 2009). The lesion damage can be formed by stimulus such as ROS. The strand breaks damage of the DNA fragmentation can either be a single strand breaks (SSB) which can still activate cell death or in worst cases can be a double strand breaks (DSB) (Doherty \& Jackson, 2001).

\section{Methods used in assessing apoptosis in bovine embryos}

There are number of techniques for apoptosis detection in cattle embryos both morphologically and genetically. One of the morphological technique that is used in embryos is the TUNEL method. The TUNEL method uses the deoxynucleotidyl transferase (TdT) enzyme. These enzyme allows the evaluation of DNA breaks by binding to the 3-hydroxyl end of the DNA breaks. Moreover, the breaks can be highlighted by fluoresce of the TdT enzyme through fluorescent microscopy (Vandaele et al., 2008; Yu, 2015). The molecular evaluation of apoptosis in embryos can be achieve through the use of Reverse Transcriptase Polymerase Chain Reaction (RT-PCR). RT-PCR is used by analysing the relative transcript in embryos. It incorporates the use of housekeeping genes such as the rabbit-globin RNA prior extraction of the embryo samples as a standard for estimation the quantity of the RT-PCR product (Opiela, 2009). With the use of RT PCR procedures, it is possible to gain insight into the transcriptional activity of individual oocytes and embryos by determining the relative abundances of transcripts from various developmental important genes (Wrenzycki, 2000). 
Caspase activity in cattle embryos hold a central position in apoptosis. It cleaves the caspaseactivated DNAse substrate that is responsible for the DNA fragmentation through breaking of the ends of the DNA (Sakahira et al., 1998). Therefore, apoptosis in cattle embryos can also be determined by measuring the activity of the caspase enzyme. The enzyme can be detected microscopical by the use of fluoroprobe. flouroprobe is used to incubate the embryos for an hour and the caspase activity post incubation will be assessed by fluorescence microscope (Paula-Lopes \& Hansen, 2002).

\subsection{Conclusion}

In vitro embryo production provides an excellent model of the assisted reproduction technology that contributes to increase number of offspring in beef cattle. However, the artificial environment can have detrimental effects on the embryo development. The artificial environment in IVEP may result in apoptosis due to the alteration of gene expression transcripts. Moreover, evaluation of apoptosis may serve as molecular markers for embryonic quality and identification of embryonic abnormality. 


\section{Chapter 3}

\section{Materials and methods}

\subsection{Introduction}

The research project focuses on factors involved in apoptosis on in vitro produced embryos. Detection of apoptosis methods such as d-UTP nick end-labeling (TUNEL), which allows the analysis of apoptosis in fragmented mammalian embryonic nuclei cells and caspase-3 activities which initiate apoptosis in the mitochondrion by the release of DNAse enzymes are of key importance for the evaluation of apoptosis on in vitro beef cattle embryos in these project. This chapter discuss the procedures used to achieve the three objectives done in this study. Briefly it involves beef cattle ovary collection, retrieval of oocytes to produce embryos in vitro, assessment of cell apoptosis in beef cattle in vitro embryos.

The study was approved by the Ethical Animal Care committee of the University of Pretoria (EC 140526-051) and the Ethical committee of the Agricultural research council (API).

\subsection{Material}

\subsubsection{Research facilities}

The experiments were conducted at the Agricultural Research Council: Germplasm Conservation and Reproductive Biotechnologies (GCRB) laboratories ( $25^{\circ} 55^{\prime} \mathrm{S} ; 28^{\circ} 12^{\prime} \mathrm{E}$ ) in Pretoria (Irene) South Africa.

\subsubsection{Material}

The study consists of four experiments. Samples from all the experiments were obtained from in vitro produced Bos-indicus beef cattle oocytes and embryos. Cattle ovaries were collected from Morgan abattoir three times a week, Monday, Wednesday and Fridays after slaughter. Maximum of 30 cow ovaries were collected within one hour after slaughter and transported in a thermo flask containing buffer saline (Sigma Aldrich ${ }^{\circledR}$, Germany) at a temperature of $38^{\circ} \mathrm{C}$. Upon arrival at the laboratory, oocytes were immediately retrieved by aspiration method as described under point 3.2.1 (figure 2). A total of \pm 900 oocytes were collected per week for the study over five-month period. An amount of \pm 1200 oocytes were used for maturation experiments from the study and a total of \pm 16800 were used for the embryo production studies. 


\subsection{Methodology}

Table 3.1 provides a brief summary of the four experiment conducted in this study.

Table 3. 1. Summary of primary activities performed for the four experiments

Experiment Activity

Experiment 1

Experiment 2

Experiment 3

Experiment 4
In vitro maturation at four temperature (39, 41, 42

$\& 43^{\circ} \mathrm{C}$ ) and subsequent embryo production post maturation using two favourable maturation temperature.

Hoechst 33323 staining of produced blastocyst.

Caspase 3 activity on in vitro embryos using 96 well thermoscientific microplate reader (BioTek, USA).

Assessment of DNA fragmentation on in vitro embryos using tunel assay method recommended by Opiela (2009).

The first experiment was aimed at investigating the extrusion of the first polar bodies post in vitro oocyte maturation at four different temperatures namely: $39,41,42$ and $43{ }^{\circ} \mathrm{C}$. The extrusion of the first polar bodies were examined 24 hours post maturation. Oocytes matured from the most favourable two maturation temperatures (39 and $41{ }^{\circ} \mathrm{C}$ ) were used for subsequent embryo development. For subsequent embryo production, all oocytes from both groups ( 39 and $41^{\circ} \mathrm{C}$ ) were subjected to the normal embryo production $\left(39^{\circ} \mathrm{C}, 5 \%\right.$ Oxygen, $5 \%$ Carbon dioxide and $100 \%$ humidity (Rynkowska et al., 2011).

The second, third and fourth experiments were performed from embryo samples that were selected from oocytes matured at 39 and $41^{\circ} \mathrm{C}$ incubation temperatures. Embryos were divided into groups namely embryos before embryonic genome activation (2-4 cell stages), after embryonic genome activation ( $\geq 8$ cell stages) and Blastocysts (Memili \& First, 2000). A total number of 200 embryos were used for each experiment. From the 200 embryos, 100 
were for oocytes matured at $41^{\circ} \mathrm{C}$ and 100 for oocytes matured at $39{ }^{\circ} \mathrm{C}$ group. Each experiment was repeated six times.

The second experiment aimed at morphological evaluation of produced embryos from both (39 and $41^{\circ} \mathrm{C}$ ) matured oocytes. At day 7 of embryo production, blastocyst from oocytes on both maturation temperature groups were stained with Hoechst 33323 (Sigma Aldrich ${ }^{\circledR}$, Isreal) for nuclei cell count.

The third experiment investigated the caspase 3 activities on in vitro produced embryo following 39 and $41^{\circ} \mathrm{C}$ maturation temperatures, while the fourth experiment involved evaluation of fragmented DNA of in vitro embryos matured at 39 and $41{ }^{\circ} \mathrm{C}$ incubation temperatures using tunel assay method (Opiela, 2009).

\subsection{In vitro embryo production}

\subsubsection{In vitro oocytes maturation}

Prior to retrieval of oocytes, the ovaries as represented on figure 3.1 were washed twice with buffer saline (Sigma Aldrich ${ }^{\circledR}$, Germany) to remove blood contamination from slaughtered donor cows and they were sprayed with $70 \%$ alcohol (Ethanol, Sigma Aldrich ${ }^{\circledR}$, Germany) for further preclusion of contamination. The oocytes were then retrieved by aspiration method shown in figure 3.2 that required 18-gauge needle and 10ml syringe (Bohlooli et al., 2015).

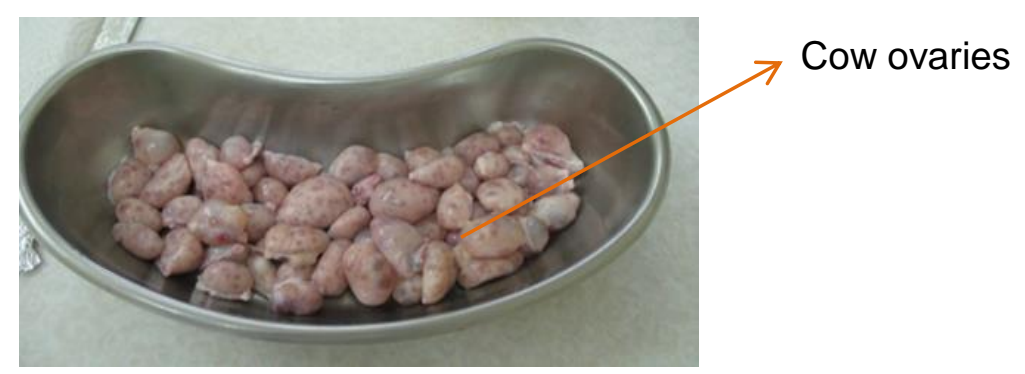

Figure 3.1 Beef cattle ovaries (ARC- Germplasm Reproduction Biotechnologies (GCRB) lab).

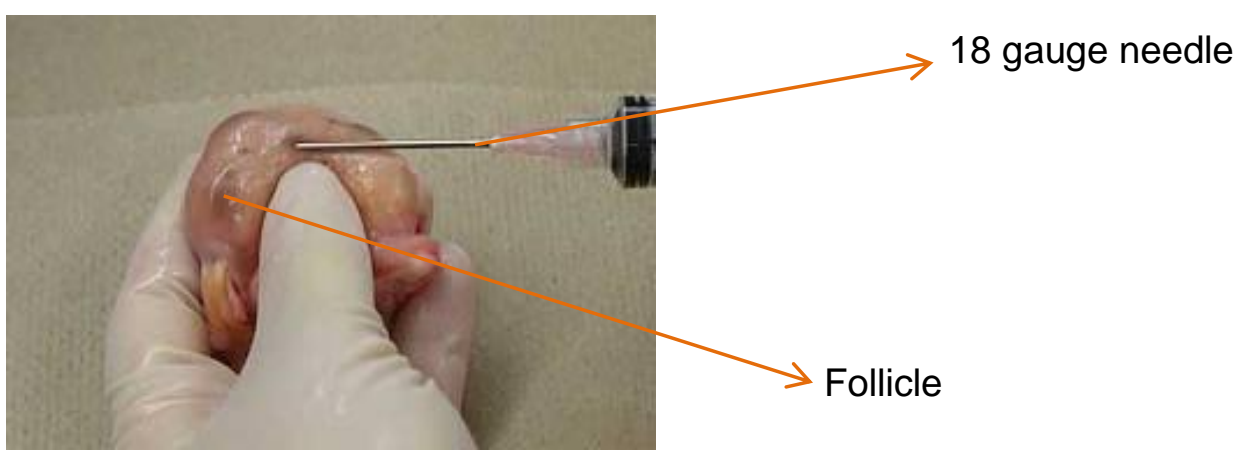

Figure 3. 2 Aspiration method of oocytes retrieval (ARC- GCRB lab) 
Post oocytes retrieval, cumulus oocyte complexes (COCs) with greater than or equal to three layers of cumulus cells (Melka et al., 2010) were selected under Olympus microscope (New York microscope Co, USA) as represented in figure 3.3. The selected COCs were washed twice, firstly in $3 \mathrm{ml}$ tissue culture medium (M-199 + 10\% FBS (Fetal bovine serum (Sigma Aldrich $^{\circledR}$, Germany) three times and secondly washed in $3 \mathrm{ml}$ modified Dulbecco phosphate buffer saline (DPBS, Sigma Aldrich ${ }^{\circledR}$, USA) three times. The COCs post washing were randomly allocated into $39,41,42$ and $43^{\circ} \mathrm{C}$ maturation temperatures and matured in $500 \mu \mathrm{l}$ of M-199 + FSH/LH/EST (40 $\mu$ l Follicular stimulating hormone, Sigma Aldrich ${ }^{\circledR}$, USA)/20 $\mu \mathrm{l} \mathrm{LH}$ (Luteinizing hormone, Sigma Aldrich ${ }^{\circledR}$, USA) and $20 \mu$ IST (Estradiol, Sigma Aldrich ${ }^{\circledR}$, USA) maturation medium covered with $250 \mu$ of mineral oil (Sigma Aldrich ${ }^{\circledR}$, USA) at $5 \% \mathrm{CO}_{2}, 5 \%$ $\mathrm{O}_{2}$ and $100 \%$ humidified air then incubated for 24 hours for in vitro maturation. The oocytes were 50 per maturation well.

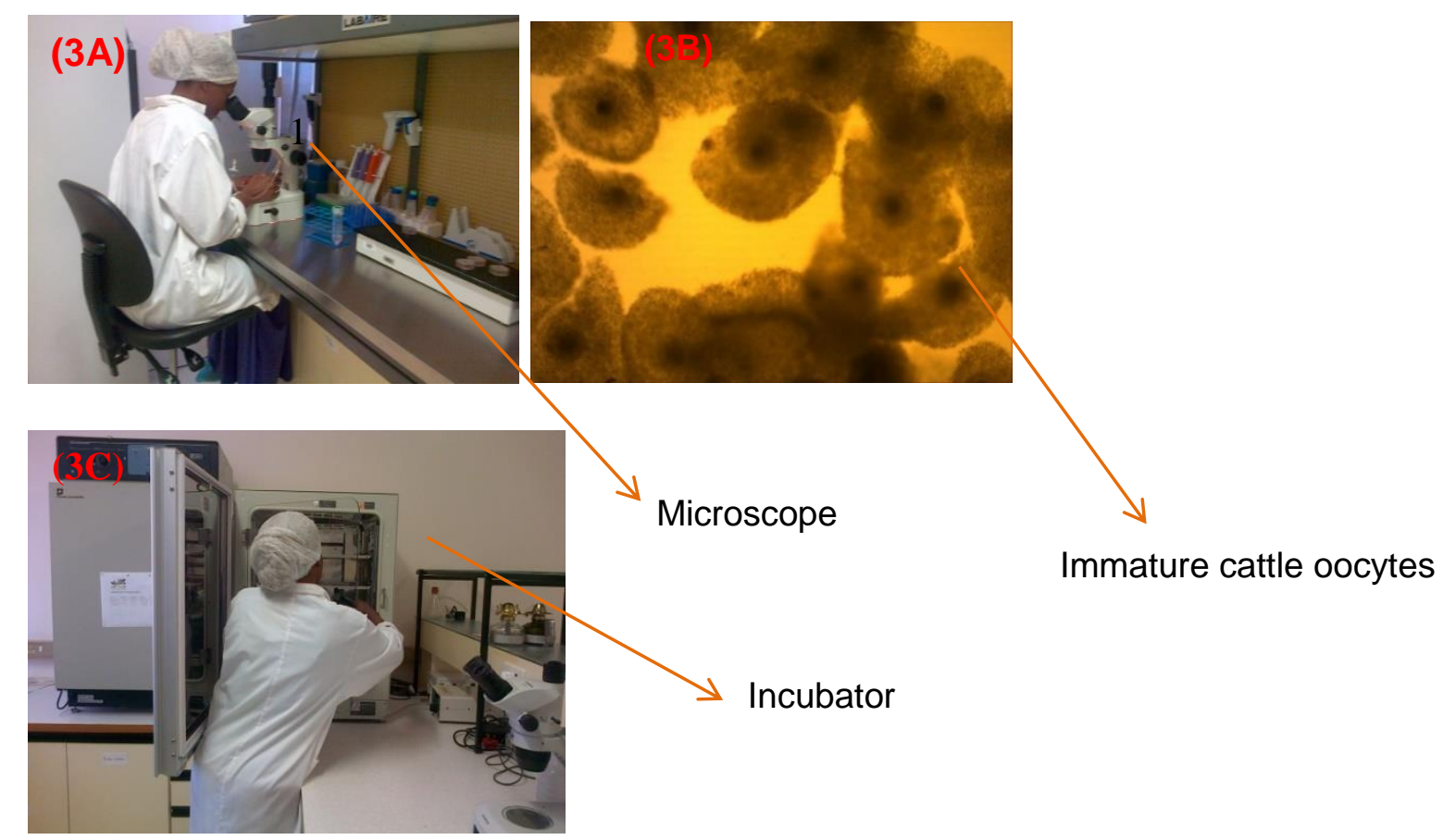

Figure 3. 3 Bovine oocytes in vitro maturation performed at the ARC lab, GCRB section. $3 \mathrm{~A}=$ microscope for oocyte search, $3 \mathrm{~B}=$ oocytes and $3 \mathrm{C}=$ incubator

\subsubsection{Polar body extrusion}

After 24 hours of maturation, oocytes from each temperature were removed from the incubator and vortexed in $200 \mu$ l of M-199 medium supplemented with FBS (Sigma Aldrich®, Germany) (M-199 + $10 \%$ FBS, Sigma Aldrich ${ }^{\circledR}$, Germany) for 1 minute 30 seconds and were transferred into a dish containing $3 \mathrm{ml}$ of (M-199 $+10 \%$ FBS, Sigma Aldrich ${ }^{\circledR}$, Germany) for polar body extrusion. The assessment was performed using Olympus 1x 71 microscope (New York microscope Co, USA) at $20 \times / 0.45 \mathrm{Rc}_{2}$ magnification. Based on the polar body extrusion 
outcomes from the four incubation temperature, the preferred two incubation temperatures were selected for subsequent embryo development.

\subsection{In vitro fertilization}

\section{Matured oocytes preparation for fertilization}

Matured oocytes were washed five times in five drops of $100 \mu \mathrm{l}$ pre-warmed Bracket and Oliphant (BIO-IVF) medium covered with $250 \mu$ of mineral oil (Sigma Aldrich ${ }^{\circledR}$, Germany). The BIO-IVF medium consists of: Sodium chloride $\left(\mathrm{NaCl}\right.$, Sigma Aldrich ${ }^{\circledR}$, USA), Potassium chloride ( $\mathrm{KCl}$, Sigma Aldrich ${ }^{\circledR}$, USA), Sodium phosphate (NaH2PO4.H2O, Sigma Aldrich $\AA_{\text {, }}$ USA), Magnasium chlroride ( $\mathrm{MgCl} 2.6 \mathrm{H} 2 \mathrm{O}$ Sigma Aldrich $\left.{ }^{\circledR}, \mathrm{USA}\right)$, Calcium chloride $\left(\mathrm{CaCl} 2.2 \mathrm{H} 2 \mathrm{O}\right.$, Sigma Aldrich $\left.{ }^{\circledR}, \mathrm{USA}\right)$, Glucose (Sigma Aldrich $\left.{ }^{\circledR}, \mathrm{USA}\right)$, Antibiotic-Antimycotic (Gibco, Germany), Phenol Red, NaHCO3 (sodium bicarbonate, Sigma Aldrich ${ }^{\circledR}$, USA), and Sodium pyruvate (Na-Pyruvate, Sigma Aldrich®,USA). After washing, 20-25 oocytes were then transferred in each of the seven drops of $50 \mu \mathrm{l}$ of pre-warmed Bio-IVF medium covered with $250 \mu \mathrm{l}$ of mineral oil for fertilization (Sigma Aldrich ${ }^{\circledR}$, Germany).

\subsubsection{Semen thawing}

Frozen-thawed Nguni semen straws from a single bull were used for in vitro fertilization. Briefly, frozen semen with straw size $0.25 \mathrm{ml}$ (Embryo plus, South Africa) was thawed for 30 seconds in air and a minute in warm water at a temperature of $37^{\circ} \mathrm{C}$. Semen was washed twice by centrifugation at $1500 \mathrm{RPM}$ for eight minutes per centrifugation at $37^{\circ} \mathrm{C}$ in $4 \mathrm{Im}$ of pre warmed sperm wash medium which consist of BIO-IVF solution, Caffeine (Sigma Aldrich $\AA$, USA) and BSA (Sigma Aldrich®, USA) based on protocol by Yang \& Rajamahendran (2002). After the first centrifugation, the supernatant was discarded and new $4 \mathrm{ml}$ of sperm wash medium was added into the semen and centrifuged for the second time. The supernatant was again discarded for the second centrifugation and spermatozoa pellet remained. Then, $50 \mu \mathrm{l}$ sperm wash $\mathrm{X}$ number of oocytes drops was added in the sperm pellet. The matured oocytes in each drop was then fertilized with $50 \mu \mathrm{l}$ sperm pellet at a concentration of $265 \times 10^{6}$ sperm cells $/ \mathrm{ml}$ and incubated in Bio-IVF medium for six hours on day 0 of in vitro embryo production. 


\subsection{In vitro culture.}

\section{Zygotes preparation for in vitro culture}

Six hours post insemination presumptive zygotes were removed from fertilization drops and cumulus cells were removed by vortexing in $200 \mu$ l of pre-warmed (M199+10\% FBS) medium for one minute 30 seconds.

\subsubsection{In vitro culture of Zygotes}

Zygotes were washed five times in five drops of $100 \mu \mathrm{l}$ pre-warmed synthetic oviductal fluid medium supplement with bovine serum albumen (SOF-BSA) and 20-25 zygotes were transferred in seven drops of $50 \mu \mathrm{l}$ (SOF-BSA) covered with $250 \mu \mathrm{l}$ mineral oil (Sigma Aldrich ${ }^{\circledR}$, Germany) and were then cultured for 48 hours in a modular chamber with $5 \%$ oxygen and 5 $\% \mathrm{CO}_{2}$ mixed gas added for a minute. The SOF-BSA medium consists of Sodium Chloride $(\mathrm{NaCl}$, Sigma Aldrich $\AA$, USA), Potassium Cloride ( $\mathrm{KCl}$, Sigma Aldrich $\AA, \mathrm{USA})$, Potassium phosphate monobasic (KH2PO4, Sigma Aldrich ${ }^{\circledR}$, USA), Magnesium sulfate heptehydrate (MgSO4.7H2O, Sigma Aldrich $\AA$, USA), D-Lactic acid sodium salt (C3H5O3, Sigma Aldrich $\AA$, USA), Antibiotic-Antimyotic, Sodium bicarbonate (NaHCO3, Sigma Aldrich $\AA$, USA), Phenol Red (Sigma Aldrich ${ }^{\circledR}$, USA), Ultrapure water (CRITI CARE (pty), South Africa), BSA (Sigma Aldrich $\AA^{\circledR}$, USA) and Pyruvic acid (Sigma Aldrich ${ }^{\circledR}$, USA). The sperm exposed oocytes were examined for initial cleavage after 48 hours of culture (Day two of in vitro embryo production). The embryos were transferred to a new pre-warmed medium of synthetic oviductal fluid supplemented with fetal bovine serum (SOF-FBS) which consist of SOF stock solution and FBS (Sigma Aldrich $\AA$, USA) for subsequent embryo development post first 48 hours of culture. At 72 hours of incubation (Day five of in vitro embryo production), $20 \mu$ l of old (SOF-FBS) culture medium was removed and replaced with $20 \mu$ fresh medium of (SOF-FBS) per culture drop. Seven days after culture blastocyst development was then examined (B r y $\nmid$ a \& Trzcińs k a, 2011).

\subsubsection{Nuclei cell analysis}

Blastocysts developed from matured oocytes incubated at both 39 and $41{ }^{\circ} \mathrm{C}$ temperatures were removed. Expanded and hatched blastocyst were then washed twice in $3 \mathrm{ml}$ of prewarmed MPBS medium. $250 \mu \mathrm{l}$ of Hoechst 33342 (Sigma Aldrich ${ }^{\circledR}$, Isreal) was diluted in 2.5 $\mathrm{ml}$ sterile water (CRITI CARE (pty), South Africa) to make-up stock 1 of the Hoechst solution and store at $4{ }^{\circ} \mathrm{C}$. Stock 2 of the Hoechst solution was prepared by adding $8 \mathrm{ml}$ Dulbecco phosphate buffer saline, Sigma ${ }^{\circledR}$, Germany (DPBS) and $2 \mathrm{ml}$ Glycerol inside a $10 \mathrm{ml}$ tube. On the day of use, $20 \mu \mathrm{l}$ of Stock 1 was added into $10 \mathrm{ml}$ of stock 2. Based on the procedure of 
Bohlooli et al. (2015), the embryos were transferred to a clean microscope glasslide (Labcon, Germany). consequently, four small drops of a pen pointer of Vaseline (Johnsons and Johnsons (pty) South Africa) around the embryo drop were made and a cover slip (Labcon, Germany) was placed over the slide and gently squeezed until it touches the embryo drop. A minimum volume of $5 \mu$ of Stock 2 solution were added gently on the sides of the cover slip until the whole area under the slip was covered. The end of the cover slip was sealed using colorless nail polish (Essence, New York), and allowed to dry for three hours before counting the nuclei cells. Staining and mounting of the embryos was performed with the laboratory lights dimmed (Melka et al., 2010). Nuclei cell count were evaluated using Computer sperm analyser ${ }^{\circledR}$ v 3.4.0-english version and Olympus B X51 epifluorescence microscope at $60 \mathrm{X}$ magnification, represented on figure 3.4 at the ARC (germplasm lab).

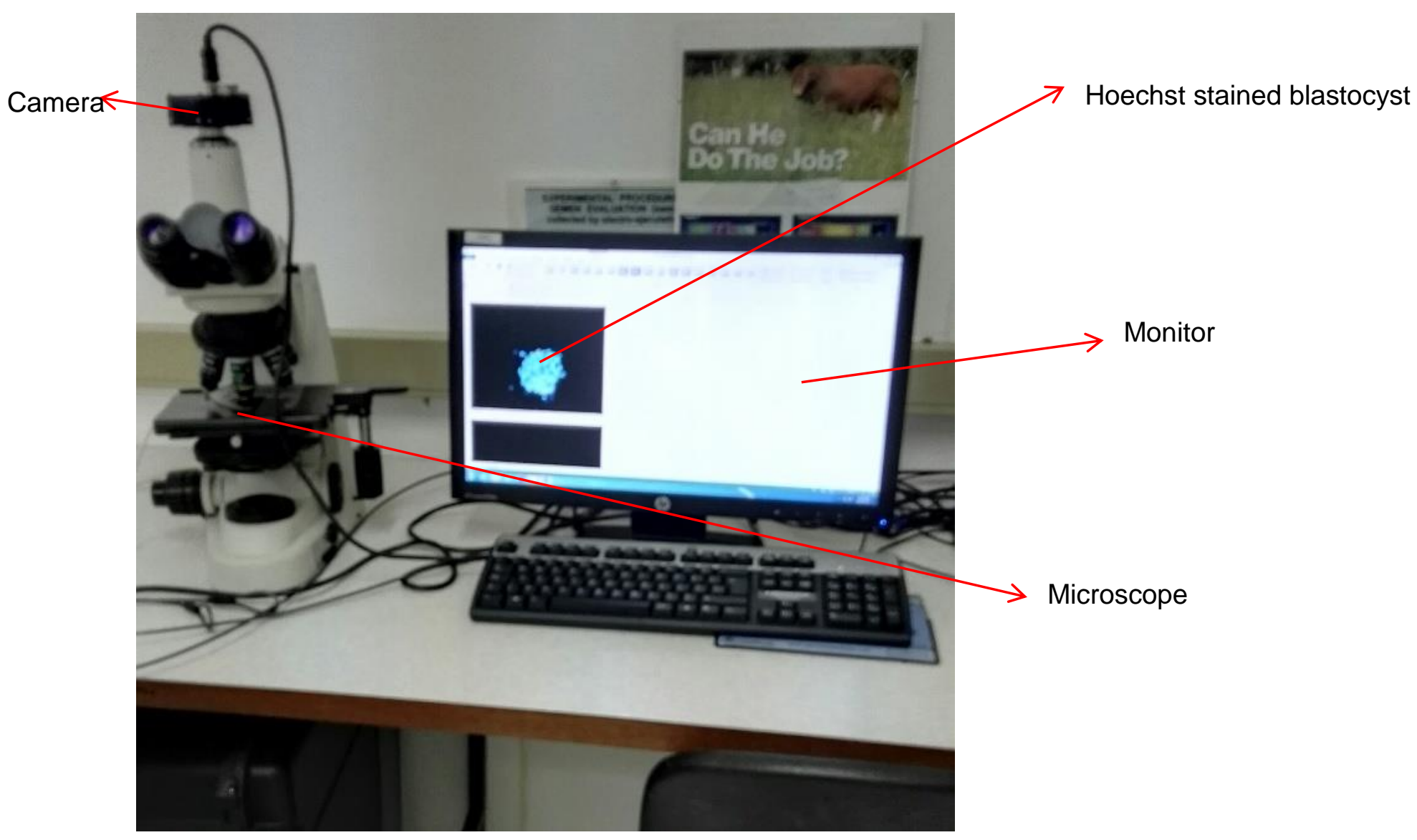

Figure 3. 4 Hoechest blastocyst staining using Computer Sperm Analyser® (Barcelona,Spain) GCRB lab

\subsection{Caspase-3 activity of produced embryos from oocytes matured at two (39 and 41 $\left.{ }^{\circ} \mathrm{C}\right)$.}

A total number of 200 embryos of 2-4 cell development from the oocytes incubated at 41 and the $39^{\circ} \mathrm{C}$ maturation temperature were removed from the embryo culture medium (SOF-BSA) 
at day two of insemination and a total number of 200 embryos ( $\geq 8$ cell) stage were removed at day five, while blastocysts were removed at day seven from the culture medium. All produced embryos were washed three times in $50 \mu \mathrm{l}$ drops of pre-warmed PBS-PVP. Positive control samples were first incubated for two hours in $50 \mu \mathrm{l}$ drops of $\mathrm{H}_{2} \mathrm{O}_{2}$ prior the caspase procedure. Caspase-3 activity assay was performed using a Caspase-3 Colorimetric Activity Assay Kit (EMD Millipore, USA) according to the manufacturer's instructions. The enzyme reactions were then colorimetrically monitored at $405 \mathrm{~nm}$ and $450 \mathrm{~nm}$ reference filter with a 96 microtiter thermosceintific plate reader (USA) represented at figure 3.5 (Power Wave XS; BioTek, USA) by reading the OD (Optimal density) values (Hwang et al., 2012).

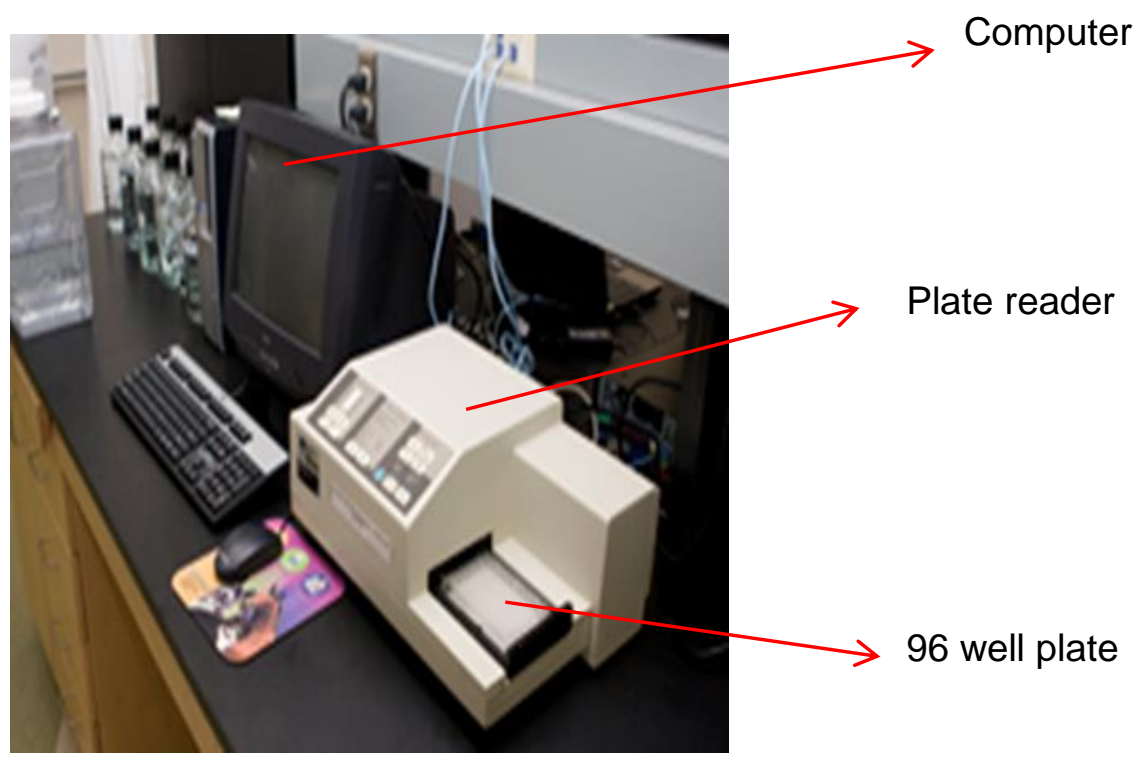

Figure 3. 5 Microplate reader ARC-Nutrition section lab

\section{DNA fragmentation of produced embryos from oocytes matured at two (39 and 41 $\left.{ }^{\circ} \mathrm{C}\right)$.}

DNA fragmentation was examined using the Tunel assay method (Sakatani et al., 2013). Tunel assay was performed using the Alexa Fluor® 488 assay kit (Eugen, USA) according to the manufacture instructions. A total number of 200 embryos of 2-4 cell developed from oocytes incubated at 39 and $41{ }^{\circ} \mathrm{C}$ maturation temperatures were removed from embryo culture medium SOF-BSA at day two of insemination and a total number of 200 embryos $\geq 8$ cell embryos were removed at day five of insemination. Blastocysts were removed on day seven of in vitro culture for the tunel assay experiment. Embryos from both development group and blastocysts were washed 3 times in $50 \mu$ drops of pre-warmed PBS- PVP (phosphate buffer saline-polyvinylpyrrolidone, Sigma Aldrich $\AA$, Germany) for two min per wash by transferring the embryos from drop to drop. The embryos were then fixed in $50 \mu$ drops of $4 \%$ paraformaldehyde solution (Sigma Aldrich ${ }^{\circledR}$, Germany) prepared in PBS at $\mathrm{pH} 7.4$ for one $\mathrm{h}$ 
at room temperature. After fixation embryos were then washed 3 times in $50 \mu \mathrm{l}$ drop of PBS/ PVP by transferring them from drop to drop (2 minutes for each wash) and Incubated in a 50 $\mu \mathrm{l}$ drop of $0.5 \%(\mathrm{v} / \mathrm{v})$ Triton X-100, $0.1 \%(\mathrm{w} / \mathrm{v})$ and sodium citrate (Sigma Aldrich $\circledast$, USA) solution for permeabilization. Post permealization embryos were stored for 30 minutes at room temperature in a humidified box (Silva et al., 2013).

Preparing a Positive Control

Positive control embryos were incubated for two hours in $2 \%$ hydrogen peroxide $\left(\mathrm{H}_{2} \mathrm{O}_{2}\right)$. Followed by the addition of $100 \mu \mathrm{l}$ of the DNase I solution mixture to each embryo sample and incubate for 30 minutes at room temperature. The slides were washed once with deionized water (lifetechnologies ${ }^{\circledR}$, South Africa) and proceed to TdT (Terminal Deoxynucleade tansferase Reaction) Reaction. DNase I solution consists of $89 \mu$ l Deionized water, $10 \mu \mathrm{l}$ DNase I buffer and $1 \mu \mathrm{l}$ DNase I. Negative control embryos were performed without the addition of DNase I solution mixture. Post negative and positive control preparation, the samples preceded to the fixation and permibilization procedures mentioned in 3.7.

All experimental samples proceeded to the TdT reaction according to the manufacturer instruction using the Click-iT® tunel assay (Eugen, USA). Post completion of the preparation of the samples, the samples were mounted on a slide and covered with a cover slip in a similar procedure performed in 3.6.3 for imaging analysis. Imaging analysis was performed using the Alexa Fluor® 488 emission (Barcelona, Spain) at 519 (nm) (Silva et al., 2013).

TUNEL index was also performed on produced blastocysts from both maturation group to evaluate the percentage of tunel positive. TUNEL index $=$ (no. TUNEL-positive nuclei, fragmented and condensed)/ (total no. of nuclei) × 100 (Bryla \& Trzcińska, 2011).

\subsection{Statistical analysis}

Data was collected for polar body status, embryo production, caspase 3 activity and DNA fragmentation on two different temperatures (39 and $41{ }^{\circ} \mathrm{C}$ ). The data was then analysed as a Complete Randomized Design with two treatments replicated six times. An Analysis of Variance (ANOVA) was performed. Shapiro-Wilks test was used on the standardized residuals to test for deviations from normality (Shapiro-Wilk, 1965) and means of significant effects were compared using Student's t-LSD (Least Significant Differences) at the 95\% confidence interval. All the above analyses were performed using SAS 9.2 Statistical Software, for continuous variables, means and standard errors were employed (SAS, 1999). 


\section{Chapter 4.}

\section{Results}

\subsection{Introduction}

In this chapter, results are presented of the three objectives that included: evaluation of maturation rates and embryo development, evaluation of caspase-3 activity at different stages of embryos and detection of fragmented DNA at different stages of embryo life.

\subsection{In vitro oocytes maturation}

Different maturation temperatures $\left(39,41,42\right.$ and $\left.43{ }^{\circ} \mathrm{C}\right)$ were tested and the results are presented in table 4.1. Figure 4.1 and 4.2 shows oocytes matured at the four temperatures. Maturation of oocytes demonstrated no significant difference on the extrusion of polar body between $41{ }^{\circ} \mathrm{C}(60.0 \pm 1.2)$ and $39{ }^{\circ} \mathrm{C}(61.3 \pm 1.0)$. and no significance difference was observed on the non-polar body at both temperatures (table 4.1). Maturation of oocytes at incubation temperatures $42{ }^{\circ} \mathrm{C}$ and $43^{\circ} \mathrm{C}$ showed significantly lower maturation rates and $43^{\circ} \mathrm{C}$ thus was the lowest in polar extrusion and higher non-polar body was observed. The higher incubation temperatures $\left(42^{\circ} \mathrm{C}\right.$ and $\left.43^{\circ}\right)$ resulted in oocytes with disrupted cytoplasm and lower maturation rate.

Table 4.1 Maturation of cattle oocytes at four incubation temperatures :39, 41,42 and $43^{\circ} \mathrm{C}$ $(\mathrm{MEAN} \pm \mathrm{SD})$

\begin{tabular}{|c|c|c|c|}
\hline Treatment & No. oocytes & Polar body (\%) & Non-polar body (\%) \\
\hline $41^{\circ} \mathrm{C}$ & 201 & $60.0 \pm 1.2^{\mathrm{a}}$ & $40.1 \pm 1.9^{b}$ \\
\hline $42{ }^{\circ} \mathrm{C}$ & 188 & $20.5 \pm 1.0^{\mathrm{b}}$ & $60.3 \pm 1.0^{\mathrm{a}}$ \\
\hline $43^{\circ} \mathrm{C}$ & 196 & $10.3 \pm 1.0^{b}$ & $80.8 \pm 1.0^{a}$ \\
\hline $39^{\circ} \mathrm{C}$ & 192 & $61.3 \pm 1.0^{a}$ & $39.1 \pm 1.5^{b}$ \\
\hline
\end{tabular}

a,b value with different supercripts within columns differ significantly $(P<0.05)$ 

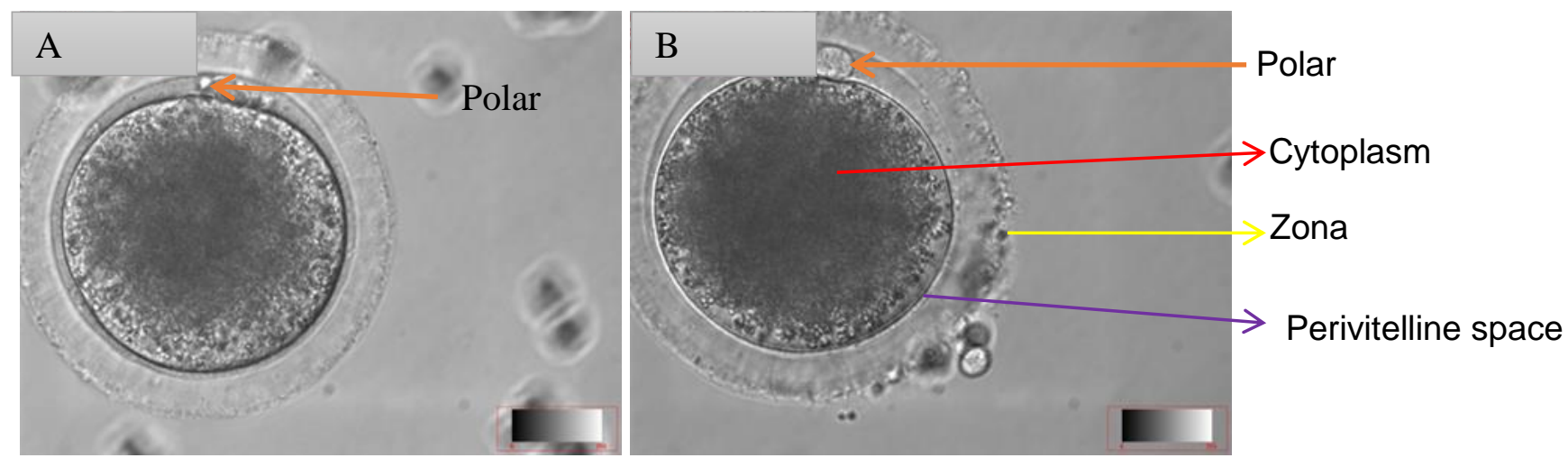

Figure 4. 1. (A) Matured oocytes from $41^{\circ} \mathrm{C}$ and (B) Matured oocytes from $39^{\circ} \mathrm{C}$
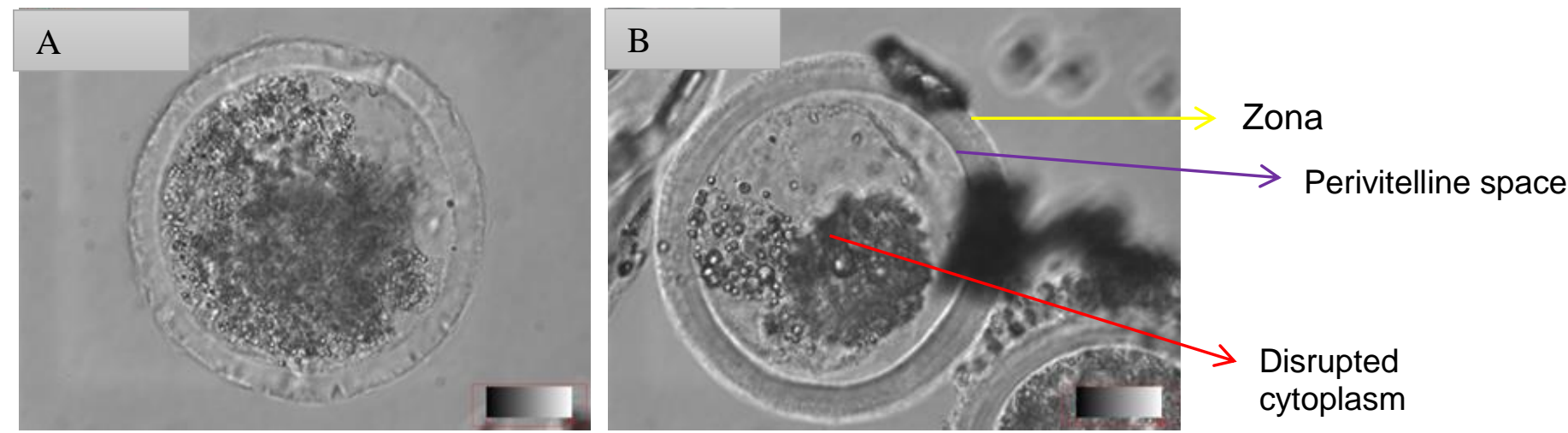

Figure 4. 2. Matured oocytes at (A) $42{ }^{\circ} \mathrm{C}$ and (B) $43^{\circ} \mathrm{C}$ maturation temperature

\subsection{In vitro embryo production and nuclei cell analysis.}

Oocytes matured at 39 and $41^{\circ} \mathrm{C}$ were selected for subsequent embryonic development as a result of higher extrusion of polar bodies compared to the other maturation temperatures (42 and $43{ }^{\circ} \mathrm{C}$ ). There was no significant difference on the development rate of 2-4 cell and 8 cell embryos from both maturation temperature 39 and $41{ }^{\circ} \mathrm{C}$ (Table 4.2). Moreover, morula percentages $\left\{41^{\circ} \mathrm{C}(19.0 \pm 14.16), 39^{\circ} \mathrm{C}(15.2 \pm 4.8)\right\}$ and blastocyst formation $\left\{39^{\circ} \mathrm{C}(11.4 \pm\right.$ 2.6) and $41{ }^{\circ} \mathrm{C}(11.2 \pm 6.3)$ \} also did not show any difference on both maturation temperatures. There was a higher significant $(P<0.05)$ effect on the nuclei cell number with higher nuclei observed in blastocyst produced from oocytes matured at $39^{\circ} \mathrm{C}(133.2 \pm 57.9)$ compared to $41^{\circ} \mathrm{C}(45.8 \pm 11.2)$. 
Table 4. 2 In vitro embryo development of matured oocytes at $39{ }^{\circ} \mathrm{C}$ and $41{ }^{\circ} \mathrm{C}$ incubation temperature (MEAN $\pm S D)$.

\begin{tabular}{|c|c|c|c|c|c|c|c|}
\hline Treatment & $\begin{array}{l}\text { No } \\
\text { oocytes }\end{array}$ & $\begin{array}{c}\text { 2-4 cell } \\
\text { (d2) }\end{array}$ & $\begin{array}{c}8 \text { cell } \\
(\mathrm{d} 2)\end{array}$ & $\begin{array}{l}\text { Cleavage } \\
\text { rate (\%) }\end{array}$ & $\begin{array}{l}\text { Morula } \\
\text { (d5) }\end{array}$ & $\begin{array}{c}\text { Blastocyst } \\
\text { (d7) }\end{array}$ & $\begin{array}{c}\text { Cell nuclei } \\
\text { (n) }\end{array}$ \\
\hline $39^{\circ} \mathrm{C}$ & 398 & $65.0 \pm 6.8^{a}$ & $39.2 \pm 6.6^{a}$ & $72.0 \pm 22.70^{a}$ & $15.2 \pm 4.8^{a}$ & $11.4 \pm 2.6^{a}$ & $133.2 \pm 57.9^{a}$ \\
\hline $41^{\circ} \mathrm{C}$ & 395 & $62.4 \pm 6.5^{\mathrm{a}}$ & $35.0 \pm 6.4^{a}$ & $60.2 \pm 18.9^{b}$ & $19.0 \pm 14.16^{a}$ & $11.2 \pm 6.3^{a}$ & $45.8 \pm 11.2^{b}$ \\
\hline
\end{tabular}

Day 7 embryos from oocytes matured at two temperatures (39 and $41^{\circ} \mathrm{C}$ ) are illustrated in figure 4.3

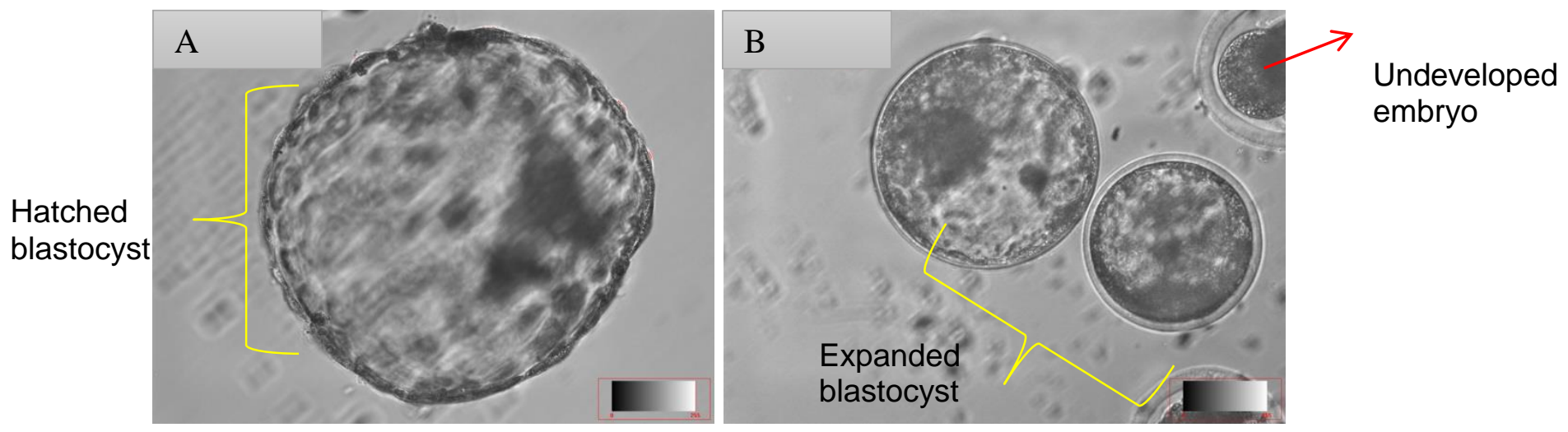

Figure 4. 3. (A) Day 7 Blastocyst from oocytes produced $39^{\circ} \mathrm{C}$ and (B) Day 7 Blastocyst from $41^{\circ} \mathrm{C}$

Blastocyst stained with Hoechst 33323 from (39 and $41^{\circ} \mathrm{C}$ ) maturation temperatures are illustrated in figure 4.4 .

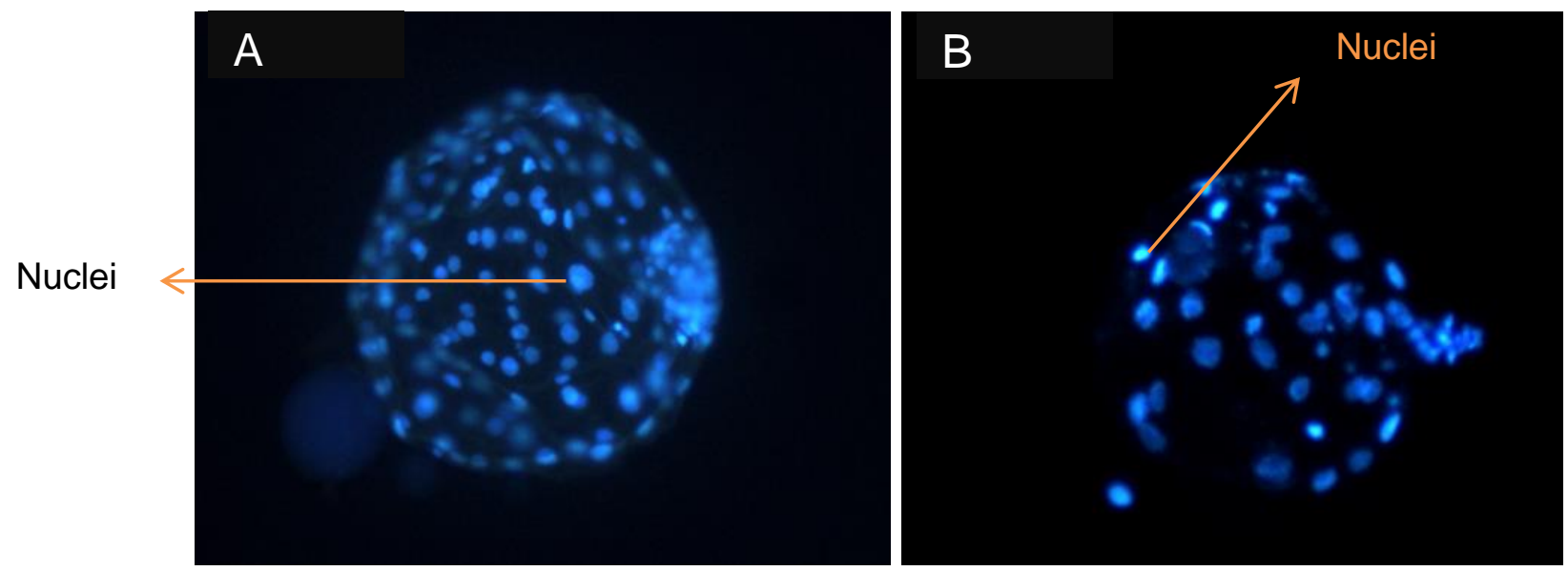

Figure 4.4 (Hoechst 33323 ) Stained blastocyst from (A) $39^{\circ} \mathrm{C}$ and (B) $41^{\circ} \mathrm{C}$ 


\subsection{Caspase- 3 activity of produced embryos from oocytes matured at two ( 39 and 41 $\left.{ }^{\circ} \mathrm{C}\right)$.}

Caspase-3 activity results of $2-4$ cell, $\leq 8$ cell and blastocyst produced are indicated in table 4.3. Embryos at 2-4 cell showed no significant differences on caspase activity from oocytes matured at both 39 and $41{ }^{\circ} \mathrm{C}$ incubation temperatures. The optimal density values (OD) obtained were comparable on $2-4$ cell embryos of oocytes incubated at $41^{\circ} \mathrm{C}(0.016 \pm 0.002)$ and $2-4$ cell embryos from oocytes matured at $39^{\circ} \mathrm{C}(0.014 \pm 0.001)$. Moreover, the OD values for embryos $\leq 8$ cell showed no significant difference on both $39{ }^{\circ} \mathrm{C}(0.022 \pm 0.007)$ and $41{ }^{\circ} \mathrm{C}$ $(0.032 \pm 0.013)$. However, caspase- 3 activity was found to be significantly higher on blastocyst from oocytes matured at $41{ }^{\circ} \mathrm{C}$ with the $\mathrm{OD}$ values $(0.053 \pm 0.005)$ compared to oocytes matured at $39{ }^{\circ} \mathrm{C}(0.037 \pm 0.012)$.

Table 4. 3 Caspase activity at different cattle embryos stages produced in vitro embryo (MEAN $\pm \mathrm{SD})$

\begin{tabular}{lllll}
\hline Temperature & Control & 2- 4 cell & $\leq 8$ cell & Blastocyst \\
$39{ }^{\circ} \mathrm{C}$ & & $0.015 \pm 0.001^{\mathrm{b}}$ & $0.022 \pm 0.007^{\mathrm{a}}$ & $0.037 \pm 0.012^{\mathrm{b}}$ \\
& & & & \\
$41^{\circ} \mathrm{C}$ & $0.815 \pm 0.049^{\mathrm{a}}$ & $0.016 \pm 0.002^{\mathrm{a}}$ & $0.032 \pm 0.013^{\mathrm{a}}$ & $0.053 \pm 0.005^{\mathrm{a}}$
\end{tabular}

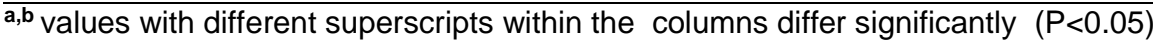

\subsection{DNA fragmentation of produced embryos from oocytes matured at two (39 and 41 $\left.{ }^{\circ} \mathrm{C}\right)$.}

Tunel assay results for DNA fragmentation on produced embryos are shown in table 4.4. There was evidence of DNA fragmentation observed in 2-4 cell embryos at $41{ }^{\circ} \mathrm{C}(6.5 \pm 2.9)$ incubation temperature compared to $2-4$ cell stage embryos at $39{ }^{\circ} \mathrm{C}(2.2 \pm 1.2)$ temperature group. However, embryos $\geq 8$ cell showed high significant difference $(P<0.05)$ at $41{ }^{\circ} \mathrm{C}(13.3$ $\pm 3)$ compared to embryos at $39{ }^{\circ} \mathrm{C}(4.5 \pm 1.9)$ and also on $2-4$ cell $(6.5 \pm 2.9)$ embryos from the same temperature group $\left(41^{\circ} \mathrm{C}\right)$. The results showed no significant difference $(P>0.05)$ on the tunel positive between $2-4$ cell $(2.2 \pm 1.2)$ and $\geq 8$ cell embryos $(4.5 \pm 1.9)$ at the $39{ }^{\circ} \mathrm{C}$ incubation temperature. However, there was significantly low tunel negatives from $\geq 8$ cell groups $(7.7 \pm 1.6)$ compared to $2-4$ cell $(18.3 \pm 4.1)$ on embryos incubated at $41^{\circ} \mathrm{C}$. Moreover, the results demonstrated equal number of tunel negative $(P>0.05)$ at $39{ }^{\circ} \mathrm{C}$ on $2-4$ cell $(18.2$ $\pm 4.8)$, 8-16 cell $(18.5 \pm 2.7)$ and $2-4$ cell embryos at $41^{\circ} \mathrm{C}(18.3 \pm 4.1)$. 
Table 4.4 DNA fragmentation using tunel assay in embryos matured at $39^{\circ} \mathrm{C}$ and $41^{\circ} \mathrm{C}$ (MEAN $\pm \mathrm{SD})$.

\begin{tabular}{llll}
\hline Temperature & Embryo group & Tunel positive (\%) & Tunel negative (\%) \\
\hline $39^{\circ} \mathrm{C}$ & $2-4$ cell & $2.2 \pm 1.2^{\mathrm{c}}$ & $18.2 \pm 4.8^{\mathrm{a}}$ \\
& $\geq 8$ cell & $4.5 \pm 1.9^{\mathrm{bc}}$ & $18.5 \pm 2.7^{\mathrm{a}}$ \\
$41^{\circ} \mathrm{C}$ & $2-4$ cell & $6.5 \pm 2.9^{\mathrm{b}}$ & $18.3 \pm 4.1^{\mathrm{a}}$ \\
& $\geq 8$ cell & $13.3 \pm 3.1^{\mathrm{a}}$ & $7.7 \pm 1.6^{\mathrm{b}}$
\end{tabular}

$\overline{\mathbf{a}, \mathbf{b}, \mathbf{c}}$ value with different supercripts within the rows differ significantly $(\mathrm{P}<0.05)$

In figure 4.5 and 4.6 the stained $2-4$ cell and $\geq 8$ cell post DNA fragmentation at both temperatures are shown respectively.
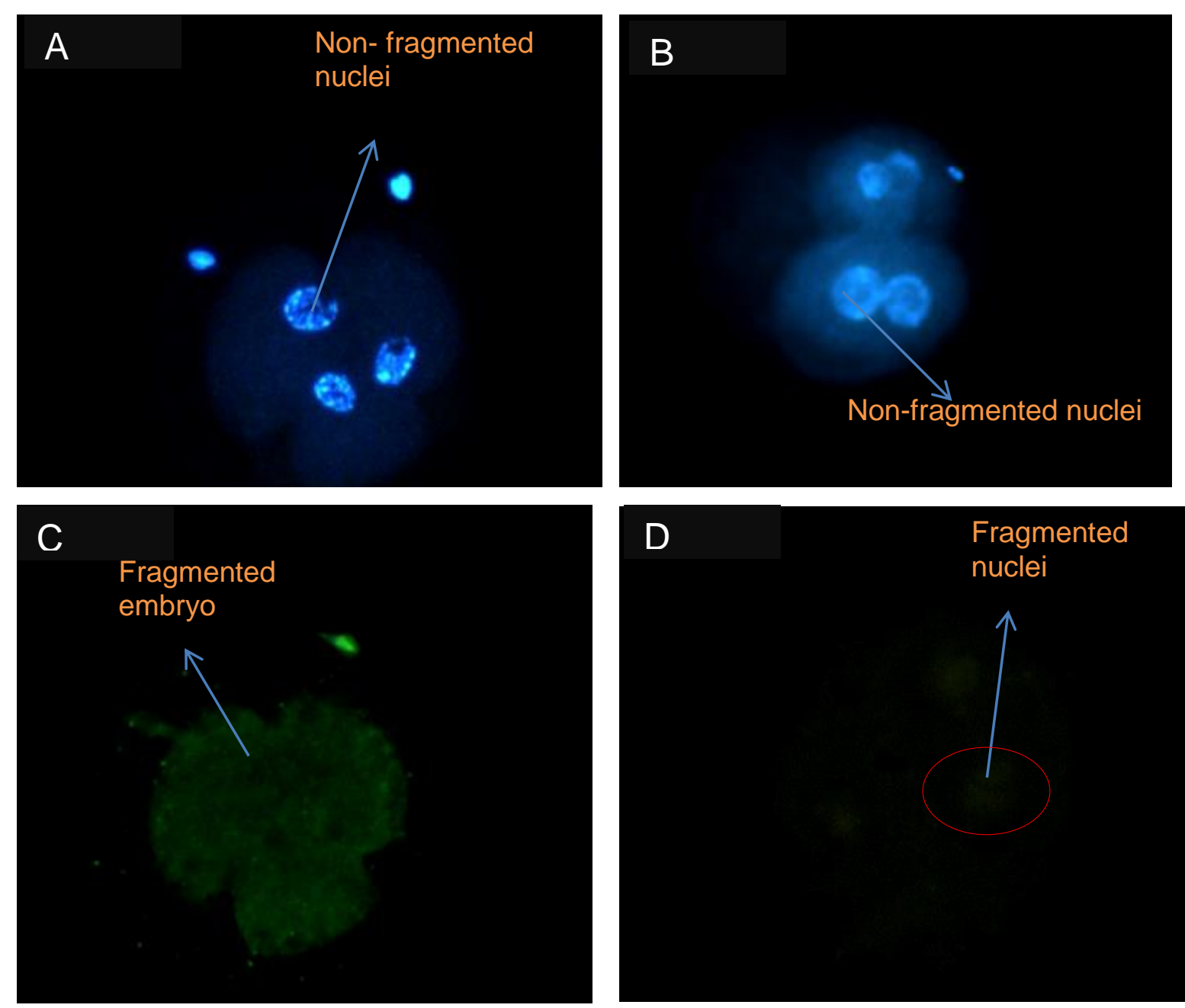

Figure 4. 5 (A) Non-fragmented 2-4 cell embryos from $41^{\circ} \mathrm{C}$ and (B) Non-fragmented 2-4 cell embryos from $39^{\circ} \mathrm{C}$. (C) Fragmented embryos from $41^{\circ} \mathrm{C}$ and (D) Fragmented embryo from $39^{\circ} \mathrm{C}$. 

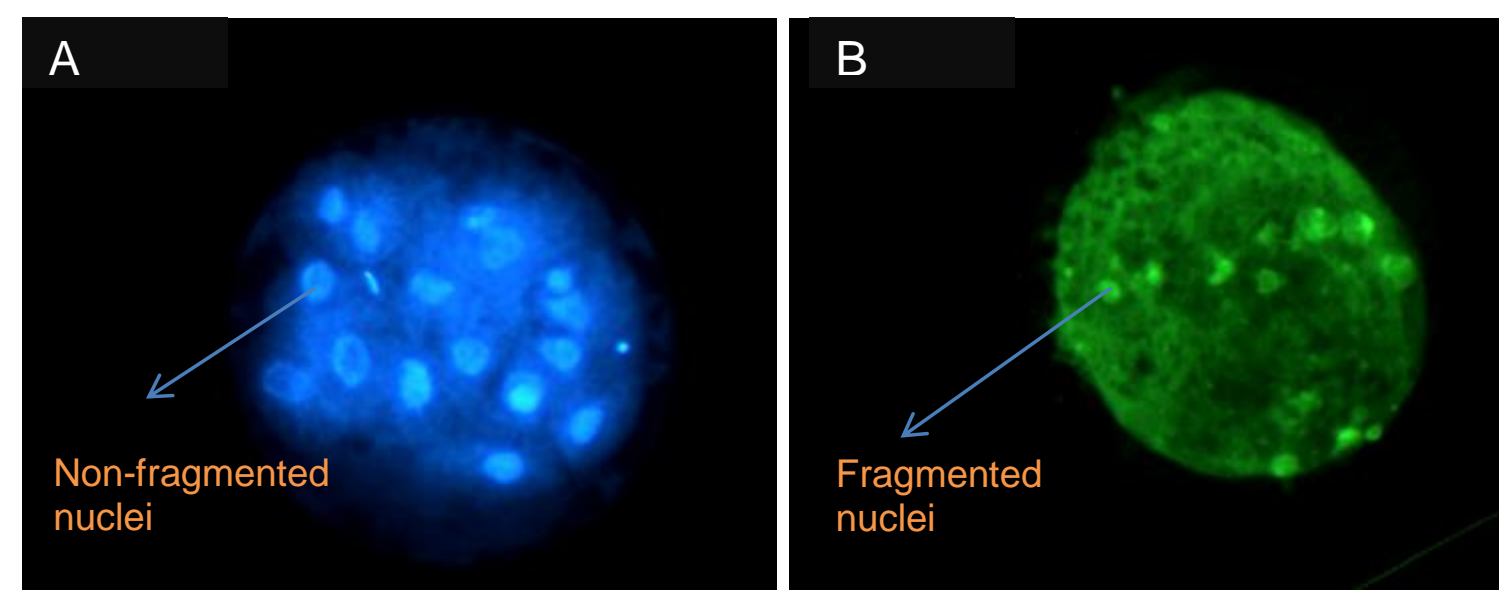

Figure 4.6 (A) Non-fragmented $\geq 8$ cell embryos from both 41 and $39^{\circ} \mathrm{C}$ (B) Fragmented $\geq$ 8 cell embryos from both $41^{\circ} \mathrm{C}$ and $39^{\circ} \mathrm{C}$

In table 4.5 the outcomes of post tunel index evaluated from blastocyst produced from $39{ }^{\circ} \mathrm{C}$ and $41{ }^{\circ} \mathrm{C}$ matured oocytes are shown. Oocytes incubated at $39{ }^{\circ} \mathrm{C}$ developed comparable number of blastocyst $(12.0 \pm 1.2)$ with oocytes matured at $41{ }^{\circ} \mathrm{C}(10.0 \pm 1.4)$. However, the number of nuclei counted at both temperature groups resulted in significantly higher level of nuclei number $(P<0.05)$ on the $39{ }^{\circ} \mathrm{C}(127.8 \pm 53.4)$ incubation temperature compared to the $41{ }^{\circ} \mathrm{C}(46.2 \pm 10.0)$. The $41^{\circ} \mathrm{C}$ incubation temperature showed higher $(\mathrm{P}<0.05)$ percentage of fragmented DNA $(21.8 \pm 21.8)$ compared $39{ }^{\circ} \mathrm{C}(10.3 \pm 4.8)$ tunel indexes $(48.0 \pm 8.2)$ than the $39{ }^{\circ} \mathrm{C}(9.7 \pm 6.7)$ incubation temperature.

Table 4. 5 Tunel assay indexis on day 7 cattle blastocyst produced in vitro (MEAN \pm SD).

\begin{tabular}{lcccc}
\hline Temperature & No blastocysts & Nuclei number & $\begin{array}{l}\text { Tunel positive } \\
\text { nuclei }(\%)\end{array}$ & $\begin{array}{l}\text { Tunel indexs } \\
(\%)\end{array}$ \\
\hline $39^{\circ} \mathrm{C}$ & $12.0 \pm 1.2^{\mathrm{a}}$ & $127.8 \pm 53.4^{\mathrm{b}}$ & $10.3 \pm 4.8^{\mathrm{b}}$ & $9.7 \pm 6.7^{\mathrm{b}}$ \\
$41^{\circ} \mathrm{C}$ & $10.0 \pm 1.4^{\mathrm{a}}$ & $46.2 \pm 10.0^{\mathrm{a}}$ & $21.8 \pm 21.8^{\mathrm{a}}$ & $48.0 \pm 8.2^{\mathrm{a}}$ \\
\hline
\end{tabular}

4.1.2 Figure 4.7 illustrate images of stained blastocyst for DNA fragmentation using tunel assay and Hoechst 33323. 
Nonfragmented Nuclei
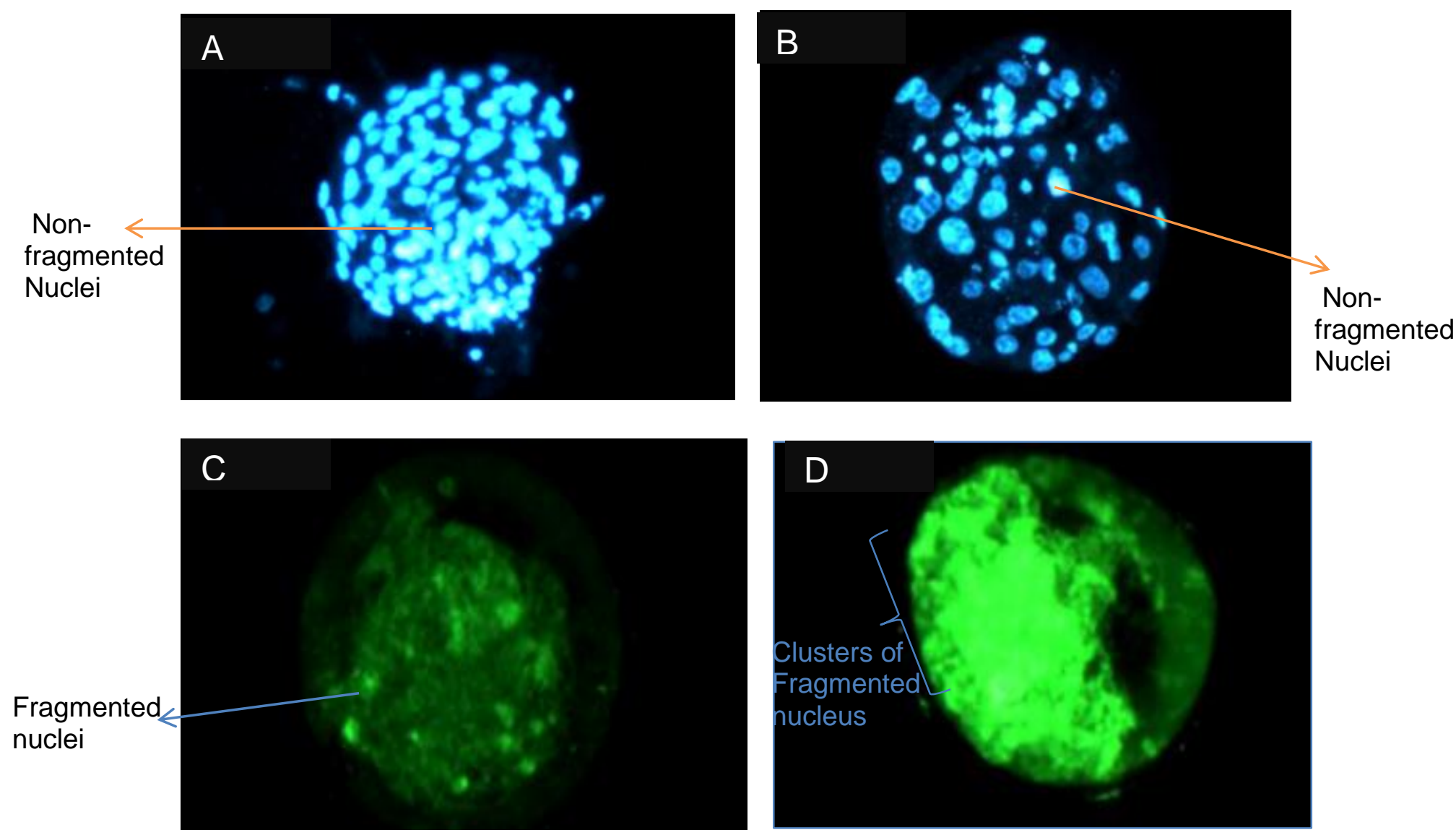

Figure 4. 7 (A \& B) Non-Fragmented blastocysts from oocytes matured $39^{\circ} \mathrm{C}$ and $41^{\circ} \mathrm{C},(\mathrm{C}$ \&D) Fragmented blastocysts from oocytes matured at both $39^{\circ} \mathrm{C}$ and $41^{\circ} \mathrm{C}$. 


\section{Chapter 5.}

\section{Discussion.}

\subsection{Introduction}

The present study of embryo production in vitro was designed to examine the effects of apoptosis on beef cattle embryos. Increased ambient temperatures and normal temperature on beef cattle oocytes during maturation was used to determine the effect of apoptosis on the normal in vitro development of embryos. The impact that the artificially environment of embryo production has on the produced embryos was of great importance in terms of cell apoptosis on produced embryos. The results obtained from this study were collectively gathered from oocyte maturation and embryo production, Caspase-3 activity and DNA fragmentation on in vitro produced embryos.

\subsection{In vitro oocytes maturation}

It has been documented that exposure of oocytes during maturation to high temperature at an earlier stage interferes with the process of oocyte maturation and may result in oocytes maturation failure. Roth \& Hansen (2004) further highlighted, during maturation period, the temperature range of $40-41^{\circ} \mathrm{C}$ may induce apoptosis through DNA damage in oocytes before fertilization of the gametes. However, in the present study in vitro maturation resulted in comparable polar body extrusion between moderate heat-stressed $\left(41^{\circ} \mathrm{C}\right)$ oocytes with the non-heated $\left(39^{\circ} \mathrm{C}\right)$ oocytes. Moreover, literature state that, when cells are exposed to high temperature, toxic chemicals and other forms of stresses, the stress protein called heat shock proteins (HSPs) or are readily synthesized or induced (Kim et al., 2002). These proteins are essential for the maintenance of cellular homeostasis and protection against environmental insults. They assist in forcing other protein with incorrect folding to adopt proper conformation and folding, they further repair damaged occurred in cells due to various stressors (Rynkowska et al., 2011). Therefore, this might have had an influence on the maturity survival of oocytes incubated at moderate high incubation temperature $\left(41^{\circ} \mathrm{C}\right)$ in this study.

The present study showed higher non maturation rates and disrupted cytoplasm at maturation temperatures of 42 and $43^{\circ} \mathrm{C}$. Conversely, Ju et al. (2005) and Roth \& Hansen (2005), argue that the effect of heat stress or any other stress on oocytes damage depends on the severity of the stress and the oocyte thermotolerance. High temperature in different cell structures and organelles can results in damage that can be regain later through formation of newly transcript 
in the cell or at some severe cases the damage can be irreversible. This confirms the irreversible damage observed in this study caused by heat shock ( 42 and $43^{\circ} \mathrm{C}$ ) in terms of dysfunctional cytoplasm compared to oocyte exposed to moderate heat shock $\left(41^{\circ} \mathrm{C}\right)$. In the study by Santos et al. (2010), it was reported that, heat stress decreases the ability of oocyte maturation in relation to the time of exposure to $41^{\circ} \mathrm{C}$ temperature. The report further indicated that $70.7 \%$ of oocytes mature when incubated at $39 \circ \mathrm{C}$, while exposure of oocytes to thermal stress at $41{ }^{\circ} \mathrm{C}$ for $3,6,12,18$ and 24 hours, lead to $45.28 \%, 35.17 \%, 12.30 \%, 9.74 \%$ and $4.60 \%$ oocytes maturation respectively. Therefore, this shows that it is not only the severity of the stress that can contribute to cell damage but the time of exposure to stress might also have an influence as well.

Different species also respond differently on exposure to heat shock, according to Mortensen et al. (2010), equine oocytes are not sensitive to physiologically high temperatures $\left(42^{\circ} \mathrm{C}\right)$ for 2 or $4 \mathrm{~h}$ at the onset of IVM. However, in the present study maturation of cattle oocytes at 42 and $43{ }^{\circ} \mathrm{C}$ was affected and resulted in higher level of non-polar formation.

\subsection{In vitro embryo production}

The present study further investigated the survivability of embryos produced from oocytes matured at both (39 and $41^{\circ} \mathrm{C}$ ) maturation temperature groups. Similar to the maturation results, the study revealed comparable results on subsequent developmental stages of embryo life amongst the two maturation groups. According to Schrock et al. (2007), oocyte maturation at $41^{\circ} \mathrm{C}$ does affect cleavage rate, subsequent embryo development after fertilization, nor the quality of developing blastocysts in the pre-implantation stage of the embryo life. These findings have been confirmed by Kim et al., (2002), Edwards et al., (2005), and Schrock et al., (2007), providing evidence that during the first part of meiotic maturation elevated temperatures has the ability to speed-up important development processes in the produced embryos. Furthermore, Silva et al. (2013), reported that the cell is able to activate cellular response in the presence of heat stress and therefore the response will minimize the damage effects course by the stressor hence, similar cleavage percentages were observed from oocytes exposed $41^{\circ} \mathrm{C}$ and that of the $39^{\circ} \mathrm{C}$ oocytes in this study. The results provided by Roth \& Hansen (2005), are also comparable with our results where oocytes incubated at $41^{\circ} \mathrm{C}$ had similar morula percentages and blastocyst percentages with the non-heated oocytes. Roth \& Hansen (2005), further highlighted that, incubation of oocytes at high temperature such as $40^{\circ} \mathrm{C}$ during fertilization do not alter with cleavage of embryos and thus tends to increase the blastocysts rates compared with oocytes fertilized at $38{ }^{\circ} \mathrm{C}$ in cattle. 
Oocytes and subsequent embryo development during heat stress is also considered to differ amounts breeds. The potential of oocytes development becomes detrimentally reduced in Bos Taurus when are collected and cultured in vitro during hot season (Friesian and Brown Swiss). The Bos indicus (Nguni and Brahman) cows (Silva et al., 2013) have an advantage and are not affected by as severely. This therefore explains the similarities on blastocyst rates on both $39{ }^{\circ} \mathrm{C}$ and $41^{\circ} \mathrm{C}$ in the present study since the ovaries were collected from Bos indicus cattle. Moreover, Bos indicus embryos shows more thermoregulatory ability during periods of heat stress than Bos taurus. In those studies, Brahman (Hernández-Ceren et al., 2004) and Romosinuano (Hernández-Ceren et al., 2004) embryos were more resistant to heat stress 41 ${ }^{\circ} \mathrm{C}$ for 6 hours compared to Holstein (Paula-Lopes et al., 2003) and Angus embryos (PaulaLopes et al., 2003). Similarly, Barros et al. (2006), Eberhardt et al. (2009) and Satrapa et al. (2011), reported that embryos of both pure and mixed Bos taurus breeds are susceptible to heat stress such as incubated at $41{ }^{\circ} \mathrm{C}$ for 12 hours than Bos indicus embryos. Moreover, there is evidence that Bos indicus and some Bos Taurus breeds (Senepol and Romosinuano) have a genetic disposition that allows their cells to have protective mechanism against from the effects of high temperatures (Satrapa et al., 2011).

\subsection{Nuclei cell analysis of produced blastocyst}

The results of embryo production on this study showed no significant differences on the blastocyst formation from both maturation temperature (39 and $41^{\circ} \mathrm{C}$ ). Thus, these findings further indicate that embryos from heat-stressed oocytes are capable of developing to more advanced stages in embryo production and may appear morphologically normal. Therefore, the day 7 blastocysts produced form this work was examined for nuclei cell number to morphologically examine the produced blastocyst. The results differed significantly $(P<0.05)$ between nuclei cell count on 41 and $39{ }^{\circ} \mathrm{C}$, where $41^{\circ} \mathrm{C}$ had very low number of nuclei than the $39{ }^{\circ} \mathrm{C}$ group. The findings are similar to the work of Sakatani et al. (2004), where percentages of embryos developing to blastocyst stage after exposure to heat shock morphologically appeared normal, however with significantly low total nuclei cell number decreased by heat shock compared with the control. Ju et al. (2005), suggested that the reduction in the blastocyst total cell number may be due to a decrease in the trophectoderm. It is considered that heat shock at metaphase II of the oocyte life exerts a more deleterious effect on future trophectoderm cells (Ju et al., 2005). However, experiment work of Sakatani et al. (2015), revealed that embryos that reached the blastocyst stage which were exposed to heat stress at the early stages of the oocyte does not affect the total cell number of the trophectoderm cell and the inner cell mass ratio any differently compared to the none heat 
shocked embryos during in vitro culture. Therefore, all these findings suggest that embryos that have passed through the effects of heat exposure might results in the reduction of cell nuclei number or restore a normal viability of nuclei cell number regardless of exposure to heat stress (Sakatani et al., 2004).

\subsection{Caspase -3 activity of produced embryos from oocytes matured at two ( 39 and 41 $\left.{ }^{\circ} \mathrm{C}\right)$.}

It has been indicated that stresses due to high temperature on cattle embryos induces cell apoptosis (Rynkowska et al., 2011; Boumela et al., 2011) and that the in vitro culture environment itself causes cell apoptosis (Farin et al., 2010). Therefore, the in vitro produced embryos in this study were examined for the activity of caspase-3 because caspases are the main initiator of apoptosis through the release of the DNAse enzyme. The release of this enzyme breaks the DNA end and results in fragmentation of the DNA (Mehmet, 2000). In this study the optimal density values for caspase- 3 activity of the 2-4 cell embryos incubated at both temperatures differed slightly $(\mathrm{P}<0.05)$ with less amount of caspase activity. The results are similar to findings of Brad et al. (2007), where there was less caspase- 3 activity on 2-4 cell embryos from both $39^{\circ} \mathrm{C}$ and $41^{\circ} \mathrm{C}$ incubation temperatures. Results from both studies indicate that, the pro-apoptotic signals can be activated to initiate apoptosis at a later stage of embryo development after the embryonic genome activation. The caspase deoxyribonuclease and the resistance of mitochondrial depolarization at 2 cell results in inhibition of apoptosis or the presence of apoptosis at a lesser amount at 2 cell stage in cattle embryo (Hansen, 2015).

The balance between the pro- apoptotic and anti- apoptotic protein is important, however the combination of high amounts of ant-apoptotic protein with the low amounts of pro-apoptotic protein can results in mitochondrial depolarization (Hansen \& Fear, 2011). Literature also show that, although the maturing oocyte can undergo apoptosis (Roth \& Hansen 2005), apoptosis can be lost or at a minimum level at 2-cell stage during minor embryo genome activation and become visible between the 8 and 16-cell stages (Gjørret et al., 2007). Apoptosis response in cattle embryos in most cases occurs in abundance during the embryonic genome activation which is from 8-16 cell stage in cattle (Fear \& Hansen, 2011; Silva et al., 2013). This might be that, DNA is highly methylated at the 2-cell stage and then becomes progressively more demethylated as development progresses until by the 8-16 cell stage when the embryo has low methylation and transcription activation (Dean et al., 2001; Park et al., 2006). Therefore, this could be reason for limited caspase activity- 3 observed from this study at 2-4 cell stage at both temperatures. 
In the present work, embryos from $\geq 8$ cell at both 39 and $41^{\circ} \mathrm{C}$ showed no difference in caspase -3 activity. These results are in contradiction with Jakob et al. (2007), where most of the caspase-3 activity staining was observed in the cytoplasm of single blastomeres in heat shocked embryos at 4 and 8 cell stages and in almost all heat shocked morulae and blastocyst (Jakob et al., 2007). The similarity of results observed in the $\geq 8$ cell stage embryos on the current study might however be in line with the report gave by Silvia et al. (2009), stating that during preimplantation development, the cattle embryo may go through a period where it is resistant to pro- apoptotic signals. Brad et al. (2007), further reported that in cattle embryos mitochondrial membrane can became artificially depolarized by carbonyl cyanide 3chlorophenylhydrazone (CCCP). In this case, caspase- 9 and caspase- 3 activation takes place but DNA fragmentation does not occur.

Silvia et al. (2009), further mention that, one possible explanation for DNA resistance to CAD may reside with the structure of DNA in the early preimplantation embryo. At the 2-cell stage, little transcription takes place and DNA is highly methylated. DNA demethylation occurs over the next several cleavage divisions. Thus, the stage of development at which susceptibility to apoptosis is acquired (8-16-cell stage) is also a time when DNA methylation is reduced and transcription is activated (Silvia et al., 2009). Given that blastocyst produced from oocytes matured at $41^{\circ} \mathrm{C}$ in this study showed higher caspase-3 activity at $39^{\circ} \mathrm{C}$ was in contrast with the findings from Roth \& Hansen, (2004). They reported that the proportion of blastocyst from both 39 and $41{ }^{\circ} \mathrm{C}$ showed no significant difference on the caspase- 3 activity where the least squares means for caspase activity were $21.6 \pm 1.6$ vs. $19.6 \pm 1.6$ respectively. However, the higher presence of caspase-3 activity on blastocyst in this study agrees with the report gave by Bryla et al. (2011), who mentioned that, as culture time increases more percentage of expanded blastocysts reveals more DNA fragmentation nuclei and activity of caspase-3 on embryos. Bryla et al. (2011), further mentioned that the longer period of in vitro culture increases the more percentage of embryos show DNA fragmentation and caspase- 3 activities.

\subsection{DNA fragmentation of produced embryos from oocytes matured at two (39 and 41 $\left.{ }^{\circ} \mathrm{C}\right)$.}

Due to the importance of DNA fragmentation by caspase-activated DNase (CAD) through activation of caspase activity, it was important to evaluate morphological changes on preimplantation embryo development in the present study. 
In this study, embryos at 2-4 cell stage of development showed significantly fewer positive apoptotic cell nuclei's at both temperatures 39 and $41^{\circ} \mathrm{C}$ compared to embryos at greater $\geq 8$ cell stage. Thus, the finding consequently suggests that the activity release of DNase from activity of caspase in 2-4 cell embryos is at minimum, hence fewer DNA fragmentation in 2-4 cell stage. The apoptotic machinery is present in 2-cell embryo but the mitochondria are resistant to apoptotic signals following apoptotic stimulus. This however, suggests that there is a developmental regulation of apoptosis at the level of the mitochondria (Fear et al., 2011). Moreover, cattle embryo remains refractory to apoptotic stimuli until the 8- to 16-cell developmental stage, hence in the present study more tunel positive nuclei's were observed from embryo $\geq 8$ cell than 2-4 cell embryos. Brad et al. (2007), repeated that both treated and non-treated embryos at the 2-4 cell stage of development represent less amount of TUNEL positive nuclei regardless of the induction of caspase initiation factors such as the procaspase9 and procaspase- 3 and therefore the DNA will also not be fragmented.

Apoptotic cell nuclei may also not become affected by stimulus such as heat shock in 2-4 cell stages of embryos. According to the findings of Sakatani et al. (2013), heat shock exposure did not affect the percentage of inseminated oocytes that cleaved or that reached the 2- to 4cell stage on day 2 after insemination. Elevated temperature does not affect the 2 cell stage or the 4 cell stage nuclei to become TUNEL positive, however, the higher incubation temperature at this stage will affect a fraction of the blastomere to became TUNEL positive at a later stage of the embryo development, mainly the 8-16 cell stage (Brad et al., 2007). Hence more blastocysts were fragmented at 41 than $39^{\circ} \mathrm{C}$ in the present study.

In conclusion, these results suggest that it is important to perform morphological quality control of pre-implantation embryos, as well as sign of apoptosis. Quality control of in vitro embryo production may results in improvement of pregnancy rate of these embryos and lead to more effective implantation and application of IVP system. 


\section{CHAPTER 6}

\section{Conclusion}

Embryo quality assessment is extremely important in case of embryo transfer but it also serves as a tool to evaluate the efficiency of in vitro embryo production systems. The presence of apoptotic cells has been identified as a negative embryo quality parameter, therefore evaluation of apoptosis will assist in selecting potential embryos for embryo transfer and successful implantation rate in South Africa.

Maturation results showed similar extrusion of polar bodies between 39 and $41^{\circ} \mathrm{C}$, with poor results at 42 and $43{ }^{\circ} \mathrm{C}$ showing low number of polar body present. The similarity of developmental rates of embryos in all stages post maturation suggested that both maturation temperatures $\left(39\right.$ and $41{ }^{\circ} \mathrm{C}$ ) may result in embryo development, however the blastocyst quality of oocytes matured at $41^{\circ} \mathrm{C}$ was compromised, resulting in very low nuclei cell number compared to the embryos from $39^{\circ} \mathrm{C}$ maturation temperature.

Apoptotic evaluation of the produced embryos from both temperature groups (39 and $41{ }^{\circ} \mathrm{C}$ ) showed comparable optimal density values of caspase-3 activity on $2-4$ cell and $\geq 8$ cell embryos from both maturation groups. However, blastocyst produced from $41{ }^{\circ} \mathrm{C}$ maturation group showed higher optimal density values than those produced from oocytes matured at 39 ${ }^{\circ} \mathrm{C}$. furthermore, DNA fragmentation results revealed a higher presence of fragmented DNA in embryos from oocytes matured on $41{ }^{\circ} \mathrm{C}$ compared to $39{ }^{\circ} \mathrm{C}$ maturation temperature in all the developmental stages. The Tunel indexes also showed higher positive percentage in blastocysts from the $41{ }^{\circ} \mathrm{C}$ maturation group compared to the $39{ }^{\circ} \mathrm{C}$ group. The project showed presence of apoptosis in both temperature groups on in vitro embryo production, however at small amounts in the normal in vitro temperature $\left(39{ }^{\circ} \mathrm{C}\right)$, therefore, for healthy production of cattle embryos the in vitro embryo production system in South African laboratories requires supplementation of caspase inhibitors on in vitro production mediums to block the caspase reaction and improve implantation rates post transfer.

It has generally been accepted that culture conditions can have a major influence on embryo quality and it has also been shown that adequate changes of the culture environment can prevent or minimize the occurrence of apoptosis during embryo culture in vitro. Therefore, it is recommended that future studies commence on evaluation of pro and anti-apoptotic genes where pro-apoptotic genes promotes apoptosis post stimulus (Bax,Bcl-XS, Bak, Bad, Bik and 
Bid) while anti-apoptotic genes (Bcl-2, Bcl-XL, Bcl-W, Mcl-1, A1) aids to prevent cytochrome $C$ release which cleaves with the caspases to initiate apoptosis. Evaluation of these genes will aid in monitoring the activity of the caspases in the mitochondrion. The ant- apoptotic gene will assist the mitochondrion to block the release of caspases for the initiation of apoptosis. This will then generate molecular information on the produced embryo. Therefore, both the knowledge of morphological and genetic information of the embryo will then result in healthier embryos produced in vitro.

The results from this study provide baseline information of factors such as temperature, Caspase activity and DNA fragmentation in cell apoptosis on in vitro produced beef cattle embryos in South Africa. Further study can now follow where genetic mechanism can be investigated associated with cell apoptosis in these embryos. 


\section{References}

Ahmed, G., Hoelker, M., Besenfelder, U., Havlicek, V., Cinar, U., Rings, F., Held, E., Sirard., I. M., Schellander, K., Dawit, T., 2012. Molecular Mechanisms and Pathways Involved in Bovine Embryonic Genome Activation and Their Regulation by Alternative In Vivo and In Vitro Culture Conditions. Journal of Biologyof Reproduction 25;87(4):100.

Al-Katanani, Y.M., Paula-Lopes, F.F., Hansen, P.J., 2002. Effect of season and exposure to heat stress on oocyte competence in Holstein cows. Journal of Dairy Science 85:390-396.

Álvarez, C., García-Garrido, C., Taronger, R., \& González de Merlo., G. 2013. In vitro maturation, fertilization, embryo development \& clinical outcome of human metaphase-I oocytes retrieved from stimulated intracytoplasmic sperm injection cycles. Journal of Medical Research. 137: 331-338.

Arias, M.E., Ross,P.J., \& Felmer, R.N., 2013. Culture medium composition affects the gene expression pattern and in vitro development potential of bovine somatic cell nuclear transfer (SCNT) embryos. Journal of Biology Research 46: 4.

Badr, H., Bongioni, G., Abdoon, A.S., Kandil, O., \& Puglisi, R. 2007., Gene expression in the in vitro-produced preimplantation bovine embryos. Journal of Zygote 15(4):35567.

Bakri, N.M., Ibrahim, S.F., Osman, N.A., Hasan, N., Jaffar, F.H.F., Rahman, Z.A., \& Osman, K., 2016.Embryo apoptosis identification: Oocyte grade or cleavage stage. Journal of Biological Sciences 23: S50-S55.

Barnes, F.L. \& Eyestone, W.H. (1990). Early cleavage and the maternal to zygotic transition in bovine embryos. Journal of Theriogenology 33: 141-52.

Barros, C.M., Pegorer, M.F., Vasconcelos, J.L.M., Eberhardt, B.G., \& Mointeiro FM. 2006. Importance of sperm genotype (indicus vs. taurus) for fertility and embryonic development at elevated temperatures. Journal of Theriogenology 65:210.

Betteridge, K.J., 2004. New reproductive technologies in cattle: a veterinary perspective. Proceeding of the WBC congress, Quebec, Canada. Available: http://www.ivis.org 23rd World Buiatrics Congress, Quebec City, Canada, July 1116.

Betts, D.H., \& King, W.A., 2001. Genetic regulation of embryo death and senescence. Journal of Theriogenology 55: 171-191.

Betts, H., \& Madan, P., 2008. Permanent embryo arrest: molecular and cellular concepts. Journal of Molecular Human Reproduction 14(8): 445-453. 
Bin, Yu., Zhang, w, z. b., Wang,Q., Yuan, P., Yang, Y., \& Kong, J., 2015. Assessing Apoptosis Gene Expression Profiling with a PCR Array in the Hippocampus of Ts65Dn Mice. Journal of Bio-Medical Research International Volume 2015: 8.

Blanco, M.R., Demyda, S., Moreno, M.M., \& Genero, E., 2011. Developmental competence of in vivo and in vitro matured oocytes. Journal of Biotechnology and Molecular Biology Review 6(7):155-165.

Boa-Amponsem, K., \& Minozzi, G., 2006. The state of development of biotechnologies as they relate to the management of animal genetic resources and their potential application in developing countries. Background Study Paper, pp 33.

Bohlooli, S.H., Bozoğlu, Ş., \& Cedden, F., 2015. HEPES buffer in ovary-transportation medium influences developmental competence of cattle oocytes. South African Journal of Animal Science 45: 5.

Bonilla, A. Q., Oliveira, L. J., Ozawa, E. M., Newsom,M., Lucy, M. C., Hansen, P. J., 2011. Developmental changes in thermoprotective actions of insulin-like growth factor-1 on the preimplantation bovine embryo. Journal of Molecular Cell Endocrinology 332:170-179.

Boumela, I., Guillemin, Y., Gue'rin, J.F., \& Aouacheria, A., 2009.The Bcl-2 family pathway in gametes and preimplantation embryos. Journal of Gyne'cologie Obste'trique \& Fertilite'. 37: 720-732.

Boumela,I., Assou, S., Aouacheria, A., Haouzi, D., Dechaud ,H., De Vos, J., Handyside, A., \& Hamamah,S., 2011. Involvement of BCL2 family members in the regulation of human oocyte and early embryo survival and death: gene expression and beyond. Journal of Society for reproduction and fertility 141: 549-561.

Brackett, B.G, Bousquet, D, Boice, M.L, Donawick, W.J, Evans, J.F, \& Dressel, M.A., 1982. Normal development following in vitro fertilization in the cow. Journal of Biology of Reproduction 27:147-158.

Brad, A.M., Hendricks, E. M., and Hansen, P.J., 2007.The block to apoptosis in bovine two-cell embryos involves inhibition of caspase-9 activation and caspase- mediated DNA damage. Journal of Society for Reproduction and Fertility. 1741-7899.

Brevini-Gandolfi, T.A.L., \& Gandolfi, F., 2001. The maternal legacy to the embryo: Cytoplasmic components and their effects on early development. Journal of Theriogenology 55:1255-1276.

Brunelle, J.K., \& Letai, A., 2009.Control of mitochondrial apoptosis by the Bcl-2 family. Cell Science, Glance pp 437.

Brunet, S., Pahlavan, G., Taylor, S., \& Maro, B., 2003. Functionality of the spindle checkpoint during the first meiotic division of mammalian oocytes. Journal of Reproduction 126: 443-450. 
Bryla, M., \& Trzcińska, M., 2011. Apoptosis in porcine blastocysts derived from 2-4 cell in vivo produced embryos subsequently cultured in vitro. Jounal of Animal Science 11: 261-271.

Byrne, A.T., Southgate, J., Brison, D.R., \& Leese, H.J., 1999. Analysis of apoptosis in the preimplantation bovine embryo using TUNEL. Journal of Reproduction Fertility 117:97-105.

Callesen, H., 2012. Challenges in work with bovine gametes and embryos. Animal Reproduction 9 :341-344.

Camargo, L.S.A., Viana, J.H.M., Sá, W.F., Ferreira, A.M., Ramos, A.A., Vale Filho, V.R., 2006. Factors influencing in vitro embryo production. Journal of Animal Reproduction 3:19-28.

Chakravarthi, P.V., \& Balaji, N.S., 2012.Use of Assisted Reproductive Technologies for Livestock Development. Veterinary World Vol.3 (5):238-240.

Chang, M. C., 1959. Fertilization of rabbit ova in vitro. Journal of Nature 184:466-467.

Cleary, M.L., Smith, S.D., Sklar, J., 1986. Cloning and structural analysis of cDNAs for bcl-2 and a hybrid bcl-2/immunoglobulin transcript resulting from the $t(14 ; 18)$ translocation. Journal of Cell 47: 19-28.

Cleveland, D.W., Mao, Y., \& Sullivan, K.F., 2003 Centromeres and kinetochores: from epigenetics to mitotic checkpoint signaling. Journal of Cell 112: 407-421.

Cory, S., \& Adams, J.M. 1998. Matters of life and death: programmed cell death at cold spring harbor. Journal of Biochimica Biophysica Acta 1377, R25-R44.

Côté, I., Vigneault, C., Laflamme, I., Laquerre, J., Fournier, E., Gilbert, I., Scantland, S S., Gagné, D., Blondin, P., \& Robert, C., 2011. Comprehensive cross production system assessment of the impact of in vitro microenvironment on the expression of messengers and long non- coding RNAs in the bovine blastocyst. Journal of Reproduction 142: 99-112.

Crosier, A. E., Farin, P. W., Dykstra, M. J., Alexander, J. E., \& Farin, C. E., 2001. Ultrastructural morphometry of bovine blastocysts produced in vivo or in vitro. Journal of Biology of Reproduction 64:1375-1385.

Dalbies-Tran, R., \& Mermillod, P., 2003. Use of heterologous complementary DNA array screening to analyze bovine oocyte transcriptome and its evolution during in vitro maturation. Journal of Biology of Reproduction 68: 252-61.

Dang-Nguyen, T.Q., Somfai, T., Haraguchi, S., Kikuchi, K., Tajima, A., Kanai, Y., \& Nagai, T., 2011. In vitro production of porcine embryos: current status, future perspectives and alternative applications. Journal of Animal Science 82: 374382. 
Das, S.K., 2012.The Facilitative Glucose Transporter SLC2A8 Regulates Reproductive Outcomes and Growth Phenotype in Mice. Journal of Biology of Reproduction 87: 248.

Dean, W., Santos, F., Stojkovic, M., Zakhartchenko, V., \& Walter, J., 2001.Conservation of methylation reprogramming in mammalian development: aberrant reprogramming in cloned embryos. Proceeding of National Academy of Science, U S A 98:13734-13738.

Dieleman, S.J., Hendriksen, P.J.M., Viuff, D., Thomsen, P.D., Hyttel, P., Knijn, H.M., Wrenzycki, C., Kruip, T.A.M., Niemann, H., Gadella, B.M., Bevers, M.M., \& Vos, P.L.A.M., 2002. Effects of in vivo pre-maturation and in vivo final maturation on developmental capacity and quality of preimplantation embryos. Journal of Theriogenology: 5-20.

Dode, M.A.N., Dufort, I., Massicotte, L., \& Sirard, M.A., 2006. Quantitative expression of candidate genes for developmental competence in bovine two-cell embryos. Journal of Molecular Reproduction and Development. 73: 288-97.

Doherty, A.J, \& Jackson, S.P., 2001. DNA repair: how Ku makes ends meet. Journal of Current Biology 11: R920-R924.

Duncan, R.F., Hershey, J.W.B., 1989. Protein synthesis and protein phosphorylation during heat stress, recovery, and adaptation. Journal of Cell Biology 109: 14671481.

Duszewska, A.M., Trzeciak, P., \& Rąpała, Ł., 2010. Selected issues concerning biotechnology of farm animals breeding. Journal of Animal Science 4: 295306.

Duszewska, A.M., Rąpała, Ł., Trzeciak, P., Dąbrowski, S., \& Piliszek, A., 2012.Obtaining farm animal embryos in vitro. Journal of Animal and Feed Sciences 21: 217-233.

Eberhardt, B.G., Satrapa, R.A., Capinzaiki, C.R.L., Trinca, L.A., Barros, C.M., \& 2009. Influence of the breed of bull (Bos taurus indicus vs. Bos Taurus taurus) and the breed of caw (Bos taurus indicus, Bos taurus Taurus and crossbred) on the resistance of bovine embryos to heat. Journal of Animal Reproduction Science 114:54-61.

Ebrahimi, B., Valojerdi, M.R., Eftekhari-Yazdi, P., Baharvandln, H., 2010. In vitro maturation, apoptotic gene expression and incidence of numerical chromosomal abnormalities following cryotop vitrification of sheep cumulus-oocyte complexes. Journal of Assistant Reproduction Genetics 27:239-246.

Edwards, J. L., \& Hansen, P. J., 1997. Differential responses of bovine oocytes and preimplantation embryos to heat shock. Journal of Molecular Reproduction and Development. 46:138-145. 
Edwards, J, L., Saxton, A, M., Lawrence, J, L., Payton, R, R., \& Dunlap, J, R., 2005. Exposure to a Physiologically Relevant Elevated Temperature Hastens In Vitro Maturation in Bovine Oocytes. Journal of Dairy Science 88:4326-4333.

Elmore, S., 2007. Apoptosis: a review of programmed cell death. Journal of Toxicology. Pathology 35: 495-516.

Enarl, M., Sakahira, H., Yokoyama, H., Okawa, K., Iwamatsu, A., \& Nagata, S., 1998. A caspase-activated DNase that degrades DNA during apoptosis, and its inhibitor ICAD. Journal of Nature, 391: 43-50.

Fabiana, F.B., Fantinato-Netoll, P., Sangallil, G.S.M., da Silveiral R., Perecinl, F. J.D., Meirelles, F.V., 2015. Challenges and perspectives to enhance cattle production via in vitro techniques: focus on epigenetics and cell-secreted vesicles. Journal of Animal Reproduction 45:1879-1886.

Fair, T., Lonergan, P., Dinnyes, A., Cottell, D. C. P., Hyttel, F. A., \& Boland, M. P., 2001. Ultrastructure of bovine blastocysts following cryopreservation: Effect of method of blastocyst production. Journal of Molecular Reproduction and Development 58:186-195.

Farin, C. E., Farin, P. W., \& Piedrahita, J. A., 2004. Development of fetuses from in vitro-produced and cloned bovine embryos. Journal of Animal Science 82: E53E62.

Farin, C. E., Farin, P. W., \& Piedrahita, J. A., 2010. Development of fetuses from in vitro-produced and cloned bovine embryos. Journal of Animal Science 82: E53E62.

Fear, J.M., \& Hansen, P.J., 2011. Developmental Changes in Expression of Genes Involved in Regulation of Apoptosis in the Bovine Preimplantation Embryo. Journal of Biology of reproduction 84: 43-51.

Galli, C., \& Lazzari, G., 2008. The manipulation of gametes and embryos in farm animals. Journal of Reproduction in Domestic Animals 43: 1-7.

Gallia, C., Duchi, R., Colleoni, S., Langutina, I., \& Lazzari, G., 2014.Ovum pick up, intracytoplasmic sperm injection and somatic cell nuclear transfer in cattle, buffalo and horses: from the research laboratory to clinical practice. Journal of Theriogenology, 81: 138-151.

García-Isperito, I., López-Gatius, F., Bech-Sabat, G., Santolaria, P., Yániz, J.L., Nogareda, C., De Rensis, F., \& López-Béjar, M., 2007 Climate factors affecting conception rate of high producing dairy cows in northeastern Spain. Journal of Theriogenology 67: 1379-1385. 
Gershon, E., Plaks, V., \& Dekel, N., 2008. Gap junction in ovary: Expression, localization and function. Journal of Molecular Cell Endocrinology 282: 18-25.

Gjørret, J.O., knijn, H.M., Dielemma S.J., Avery B., Larsson I-i., Maddox - H ytte I. P., 2003, Chronology of apoptosis in bovine embryos produced in vivo and in vitro. Journal of Biology Reproduction 69: 1193-1200.

Gjørret, J.O., Fabian, D., Avery, B., Maddox-Hyttel, P., 2007. Active caspase-3 and ultrastructural evidence of apoptosis in spontaneous and induced cell death in bovine in vitro produced pre-implantation embryos. Journal of Molecular Reproduction Development 74:961-971.

Goossens, K. Van Poucke, M. Van Soom, A. Vandesompele, J. Van Zeveren, A \& Peelman, L.J., 2005. Selection of reference genes for quantitative real-time PCR in bovine preimplantation embryos. Journal of Developmental Biology 5:27.

Graf, A., Krebs, S., Zakhartchenko, V., Schwalb, B., Blum, H., \& Wolfa, E., 2014.Fine mapping of genome activation in bovine embryos by RNA sequencing. Proceedings of Natural Academy of Science 18; 111(11): 4139-4144.

Greger, M., 2010. Transgenesis in Animal Agriculture: Addressing Animal Health and Welfare Concerns. Agriculture and Environmental Ethics DOI 10.1007/s10806010-9261-7.

Hafez, Y.M., 2015 Assisted Reproductive Technologies in Farm Animals. ICMALPS 2015, Alexandria University, Egypt.

Hendrey, J.J., Kola, I., 1991. Thermolability of mouse oocytes is due to the lack of expression and/or inducibility of Hsp70. Journal of Molecular Reproduction and Development 25: 1-8.

Hansen, P.J., 2002. Embryonic mortality in cattle from the embryo's perspective. Journal of Animal Science 80: E33-E44.

Hansen, P.J., 2006. Realizing the promise of IVF in cattle-an overview. Journal of Theriogenology 65: 119-125.

Hansen, P.J., 2007. To be or not to be - determinants of embryonic survival following heat shock. Journal of Theriogenology 68S: S40-S48.

Hansen, P. J., 2009. Effects of heat stress on mammalian reproduction. Journal of Philosophy Transection of the Royal Society 364: 3341-3350.

Hansen, P.J., 2015. Early Embryonic Loss Due to Heat Stress. Gainesville Florida, USA. Bovine Reproduction, First Edition. Inc. Published 2015 by John Wiley \& Sons, Inc.Chapter $64 \mathrm{pp}$.

Hansen, P.J., \& Fear, J.M., 2011. Cheating death at the dawn of life: Developmental control of apoptotic repression in the preimplantation embryo. Journal of Biochemical and Biophysical Research Communications 155-158. 
Hernández-Cerón, J., Chase, C. C., \& Hansen, P. J., 2004. Differences in heat tolerance between preimplantation embryos from Brahman, Romosinuano, and Angus Breeds. Journal of Dairy Science. 87:53-58.

Hill, J.R., 2014. Incidence of Abnormal Offspring from Cloning and Other Assisted Reproductive Technologies. Journal of Animal Biosciences 2: 307-321.

Hossini, A.M., Geilen, C.C., Fecker, L.F., Daniel, P.T., Eberle, J., 2005. A novel Bcl-x splice product, Bcl-xAK, triggers apoptosis in human melanoma cells without $\mathrm{BH} 3$ domain. Journal of Oncogene 14:6

http://www.ncbi.nlm.nih.gov/gene/\& http://www.ncbi.nlm.nih.gov/unists.20/07/2015

Hwang, I., Bae, H., \& Cheong, H., 2012. Mitochondrial and DNA damage in bovine somatic cell nuclear transfer embryos. Veterinary Science 14(3), 235-240.

Hwang, K., Weedin, J.W., \& Lamb, D., 2010.The use of fluorescent in situ hybridization in male infertility. Therapeutic Advances in Urology 2(4): 157-169.

Invitrobrasil, 2016. In Vitro Fertilization as a tool for the Genetics Improvement. History and Future Prospects. $\quad$ http://invitrobrasil.com.br/pdf/artigos-publicados/40perspectives-of-the-world-in-vitro-industry.pdf. 25/04/16.

Jakob, O., Gjørret, D.F., Birthe, A., \& Maddox-hyttel, P., 2007.Active caspase-3 and ultrastructural evidence of apoptosis in spontaneous and induced cell death in bovine in vitro produced preimplantation embryos. Journal of Molecular reproduction and development 74:961-971.

Jennifer, A., Hernandez, G., \& Craig, A., Gifford, B., 2013. Role of reproductive biotechnologies in enhancing food security and sustainability. Animal Frontiers. Vol. 3 ,

Jiang, Z., Sun, J., Dong, H., Luo, O., Zheng, X., Obergfell, C., Tang, Y., Bi, J., O’Neill, $\quad$ R., Ruan, Y., \& Chen, J., 2014. Transcriptional profiles of bovine in vivo preimplantation development. Journal of Genomics 15:756.

Jin, Y., Lee, J.Y., Choi, S.H., Kim, T., Cui, X.S., Kim, NH., 2007. Heat shock induces apoptosis related gene expression and apoptosis in porcine parthenotes developing in vitro: Journal of Animal Reproduction Science 100: 118-127.

Johansson, A., Appelqvist, H., Nilsson,C., Kågedal, K., Roberg, K., \& Öllinger, K., 2010. Regulation of apoptosis-associated lysosomal membrane permeabilization. Journal of Apoptosis 15(5): 527-540.

John, J., \& Parrish, M., 2013. Bovine in vitro fertilization: In vitro oocyte maturation and sperm capacitation with heparin. Journal of Theriogenology 81: 67-73. 
Jolly, C., \& Morimoto, R.I., 2000. Role of the Heat Shock Response and Molecular Chaperones in Oncogenesis and Cell Death. National cancer Institude 4;92(19):1564-72.

Ju, J., Jiang, S., Tseng, J. K., Parks, J. E., \& Yang, X., 2005. Heat shock reduces developmental competence and alters spindle configuration of bovine oocytes. Journal of Theriogenology 64:1677-1689.

Jürgen, E., \& Hossini, A.M., 2008. Expression and Function of Bcl-2 Proteins in Melanoma. Journal of Current Genomics 9: 409-419.

Jurisicova, A., \& Acton, B.M., 2004. Deadly decisions: the role of genes regulating programmed cell death in human pre-implantation embryo development. Journal of Reproduction 128: 281-91.

Kadarmideen, H.N. Mazzoni, G. Watanabe, Y.F. Strøbech, L. Baruselli, P.S. Meirelles, F.V. H. Callesen, P. Hytte. I, Ferraz, J.B.S. \& Nogueira, MFG., 2015. Genomic selection of in vitro produced and somatic cell nuclear transfer embryos for rapid genetic improvement in cattle production. Journal of Animal Reproduction. 12, n.3, p.389-396.

Kan`ka, K., Kepkova', L., \& Ne`mcova, M., 2009. Gene expression during minor genome activation in preimplantation bovine development. Journal of Theriogenology 72: 572583.

Kerr, J.F., Wyllie, A.H., Currie, A.R. 1972. Apoptosis: a basic biological phenomenon with wide ranging implications in tissue kinetics. Journal of Cancer 26: 239-257.

Kim, M., Khang, G, D., Park, Y, M., Kang, B., M., Lee, K, A., \& Kim, K., 2002. Expression pattern of HSP25 in mouse preimplantation embryo: heat shock responses during oocyte maturation. Molecular Reproduction and Development 61 3-13 (doi:10.1002/mrd.1125).

Kim, M.R., \& Tilly, J.L., 2004. Current concepts in Bcl-2 family member regulation of female germ cell development and survival. Biochimica. Biophysica. Acta 1644, 205-210.

Knijn, H, M., 2004. Gene expression and apoptosis in bovine embryos during in vitro culture and in vivo development. Journal of reproduction fertility and development 17:778-84

Ko"hler, C., Orrenius, S., \& Zhivotovsky, B., 2002. Evaluation of caspase activity in apoptotic cells. Journal of Immunological Methods 265: 97- 110.

Krajewski, S., Tanaka, S., Takayama, S., Schibler, M.J., Fenton, W. \& Reed, J.C. 1993. Investigation of the subcellular distribution of the bcl-2 oncoprotein: residence in the nuclear envelope, endoplasmic reticulum and outer mitochondrial membranes. Cancer Research 53; 4701-14. 
Laura, A., Favetta, E. J., John, W., Allan, King., Dean, H, B., 2007. High levels of p66shc and intracellular ROS in permanently arrested early embryos. Journal of Free Radical Biology \& Medicine 42: 1201-1210.

Laws, M.J., Taylor, R.N., Sidell, N., DeMayo, F.J., Lydon, J.P., Gutstein, D.E., Bagchi, M.K. \& Bagchi, I.C., 2008. Gap junction communication between uterine stromal cells plays a critical role in pregnancy-associated neovascularization and embryo survival. Journal of Development 135: 2659-2668.

Lee, A.S. 2001.The glucose-regulated proteins: stress induction and clinical Applications. Journal of Trends of Biochemical Science 26(8):504-10.

Lee, M.T., Bonneau, A.R., \& Giraldez, A.J.,2014. Zygotic Genome Activation During the Maternal-to Zygotic Transition. Rev. Journal of Cell Development Biology 2014. 30:581-61.

Lequarre, A.S., Marchandise, J., Moreau, B., Massip, A., \& Donnay, I., 2003.Cell cycle duration at the time of maternal zygotic transition for in vitro produced bovine embryos: effect of oxygen tension and transcription inhibition. Journal of Biology Reproduction 69: 1707-13.

Li, H.J., Liu, D.J., Cang, M., Wang, L.M., Jin, M.Z., Ma, Y.Z., \& Shorgan, B., 2009. Early apoptosis is associated with improved developmental potential in bovine oocytes. Journal of Animal Reproduction Science 114: 89-98.

Liu, H.C, He, Z.Y., Mele, C.A., Veeck, L.L., Davis, O.K., \& Rosenwaks, Z., 1997. Expression of IGFs and their receptors is a potential marker for embryo quality. Journal of Reproduction Immunology 38:237-245.

Lonergan, P, Rizos, D, \& Gutierrez-adan, A., 2003a. Oocyte and embryo quality: effect of origin, and culture conditions and gene expression patterns. Journal of Reproduction Domestic Animal. v.38, p.259-267.

Lonergan, P., Rizos, D., Guti'errez-Ad'an, A., Moreira, P.M., Pintado, B., De La Fuente, J., Boland, M.P., 2003b. Temporal divergence in the pattern of messenger RNA expression in bovine embryos cultured from the zygote to blastocyst stage in vitro or in vivo. Journal of Biology Reproduction. 69, 1424- 1431.

Lonergan, P., 2007. State-the-art embryo technologies in cattle. Journal of Reproduction Fertility and Development 64: 315-325.

Lonergan, P., \& Fair, T., 2008. In vitro-produced bovine embryos: dealing with the warts. Journal of Theriogenology. 69(1): 17-22.

Loureiro, B., Brad, A.M., \& Hansen, P.J., 2007 Heat shock and tumor necrosis factor-a induce apoptosis in bovine preimplantation embryos through a caspase-9 dependent mechanism. Reproduction 133: 1129-1137. 
Machatkova, M., Hulinska, P., Reckova, Z., Hanzalova, K., Spanihelova, J., \& Pospisil, R., 2008. In vitro production of embryos from high performance cows and the development of frozen-thawed embryos after transfer: a field study. Journal of Veterinarni Medicina 7: 358-364.

Mapletoft, R.J. García Guerra, A., Dias, F.C.F., Singh, J., \& Adams.G.P., 2015. In vitro and in vivo embryo production in cattle superstimulated with $\mathrm{FSH}$ for 7 days. Journal of Animal Reproduction 12: 383-388.

Mariana, P.C., Brenner, C., Marina, C. F., Andrea, G.A., Eduardo F. F., \& Tereza, ～C.C., 2012. Evaluation of developmental changes in bovine in vitro produced embryos following exposure to bovine Herpesvirus type 5. Journal of Reproductive Biology and Endocrinology 10:53.

Matwee, C., Betts, D.H., \& King, W.A. 2000. Apoptosis in the early bovine embryo. Journal of Zygote 8: 5768.

McHughes, C.E., Springer, G.K., Spate, L.D., Li, R., Woods, R., Green, M.P., Korte, S.W., Murphy, C.N., Green, J.A., Prather, R.S., 2009. Identification and quantification of differentially represented transcripts in in vitro and in vivo derived preimplantation bovine embryos. Journal of Molecular Reproduction Development 76: 48-60.

Mehmet, H., 2000. Caspases find a new place to hide. Journal of Nature 403: 29-30.

Melka, M.G., Rings, F., Ho"lker, M., Tholen, E., Havlicek, V., 2010. Expression of apoptosis regulatory genes and incidence of apoptosis in different morphological quality groups of in vitro-produced bovine pre-implantation embryos. Journal of Reproduction of Domestic Animal 45: 915-921.

Memili, E., \& First, N. L., 2000. Zygotic and embryonic gene expression in cow: a review of timing and mechanisms of early gene expression as compared with other species. Journal of Zygote 8:87-96.

Mori, M., Hayashi, T., Isozaki, Y., Takenouchi, Y., \& Sakatani, M., 2015. Heat shock decreases the embryonic quality of frozen-thawed bovine blastocysts produced in vitro. Journal of Reproduction and Development 61: 5.

Mortensena, C.J., Choib, Y.H., Inga, N.H., Kraemerb, D.C., Vogelsanga, M.M., \& Hinrichs, K., 2010. Heat shock protein 70 gene expression in equine blastocysts after exposure of oocytes to high temperatures in vitro or in vivo after exercise of donor mares. Journal of Theriogenology

Muscarella, D.E., Rachlinski, M.K., \& Bloom, S.E., 1998. Expression of cell death regulatory genes and limited apoptosis induction in avian blastodermal cells. Journal of Molecular Reproduction Development 51: 130-142. 
Nueber, E., Leutjens, C.M., Chan, A.W.S., \& Schatten, G.P., 2002. Analysis of DNA fragmentation of in vitro cultured bovine blastocysts using Tunel. Journal of Theriogenology 57: 2193-2202.

Niemann, H., Wrenzycki, C., 2000 Alterations of expression of developmentally important genes in preimplantation bovine embryos by in vitro culture conditions: implications for subsequent development. Journal of Theriogenology 53: 21-34.

Niemann, H., Kues, W.A., 2003: Application of transgenesis in livestock for agriculture and biomedicine. Journal of Animal Reproduction Science 79:291-317.

Nover, L., Scharf, K.D., 1991. Heat shock proteins. In: Nover, L. (Ed.), Heat Shock Response. CRC Press, Boca Raton, pp. 41-128.

Opiela, J., 2009. Apoptosis in preimplantation bovine embryos and methods used for its detection. Ann. Journal of Animal Science 9: 13-16.

Ozawaa, M. Sakatania, M. Hankowskid, K.E. Teradad, N. Dobbsa, K.B. Hansen, P.J., 2012. Importance of culture conditions during the morula-to-blastocyst period on capacity of inner cell-mass cells of bovine blastocysts for establishment of selfrenewing pluripotent cells. Journal of Theriogenology 78: 1243-1251.

Paramio, M.T., 2010. In vivo and in vitro embryo production in goats. Journal of Small Ruminant Respiration 89:144-148.

Park, S.Y., Kim, E.Y., Cui, X.S., Tae, J.C., Lee, W.D., Kim, N.H., Park, S.P., \& Lim, J.H., 2006. Increase in DNA fragmentation and apoptosis-related gene expression in frozen-thawed bovine blastocysts. Journal of Zygote 14: 125-131.

Paula-Lopes, F.F., \& Hansen, P.J., 2002. Heat shock induced apoptosis in preimplantation bovine embryos is a developmentally regulated phenomenon. Journal of Biology of Reproduction 66: 1169-1177.

Paula-Lopes, S., A. Lewis, P., Hajkova, W., Dean, J., Oswald, T., Forne, A., Murrell, M., Constancia, M., Bartolomei, J., \& Relk, W., 2003. Epigenetic modifications in an imprinting cluster are controlled by a hierarchy of DMRs suggesting long-range chromatin interactions. Journal of Human Molecular Genetics 12:295-305.

Paula-Lopes, F.F., Lima, R.S., Risolia, P.H.B., Ispada, J., Assumpção, M.E.O.A., \& Visintin, J.A., 2012. Heat stress induced alteration in bovine oocytes: functional and cellular aspects. Journal of Animal Reproduction 9: 395-403.

Pfeifer, F.M., Schneider, M.S.A., \& Corrêa, M.N., 2008.Factors that affect the in vitro production of bovine embryos: A review. Journal of Zygote 141:56

Picton, H.M., Harris, S.E., Muruvi, W., Chambers, E.L., 2008. The in vitro growth and maturation of follicles. Journal of Reproduction 136:703-15. 
Plourde, D., Vigneaultb, C., Laflammea, I., Blondinb, P., \& Roberta, C., 2012. Cellular and molecular characterization of the impact of laboratory setup on bovine in vitro embryo production. Journal of Theriogenology 77: 1767-1778.

Ponsuksili, S., Wimmers, K., Adjaye, J., \& Schellander, K., 2002. A source of expression profile in single preimplantation bovine embryos. Journal of Theriogenology 57: 161124.

Prabha, S., Meenambigai, T.V., Balasubramanian, S., Palanisamy, A., $\quad$ Vedamanikam, S., \& Kumanan, K., 2011. Glucose Transporter 1 Gene Expression in Developmentally Regulated in Vitro derived Ovine Preimplantation Embryos. Journal of Physiology and Pharmacology Advances 1:25 - 15.

Pursel, V.G., Wall, R.J., Exroad, C.E., Hammer, R.E., Brinster R.L., 1985. A rapid whole-mount staining procedure for nuclei of mammalian embryos. Journal of Theriogenology 24 687-700.

Raff, M.C.,1996. Constitutive expression of the machinery for programmed. Journal of cell biology 66:77

Rivera, R.M., \& Hansen, P.J., 2001. Development of cultured bovine embryos after exposure to high temperatures in the physiological range. Journal of Reproduction 121: 107-115

Rivera, R.M., Karen, L., Gregory, W. Erdos, \& Hansen, P.J., 2003. Alterations in Ultrastructure Morphology of Two-Cell Bovine Embryos Produced In Vitro and In Vivo Following a Physiologically Relevant Heat Shock. Journal of Biology reproduction 69(6):2068-77.

Rivera, R.M., Dahlgren, G.M., De Castro, E., Paula, L.A., Kennedy, R.T., \& Hansen, P.J., 2004a Actions of thermal stress in two-cell bovine embryos: oxygen metabolizm, glutathione and ATP kontent, and the time-course of development. Journal of Reproduction 128: 33-42.

Rivera, R.M., Kelley, K.L., Erdos, G.W., \& Hansen, P.J., 2004b. Reorganization of microfilaments and microtubules by thermal stress in two-cell bovine embryos. Journal of Reproduction biology 70(6):1852-62.

Rizos, D., T. Papadopoulos, F. S., Boland, M.P., \& Lonergan, P., 2002. Developmental, qualitative, and ultrastructural differences between ovine and bovine embryos produced in vivo or in vitro. Journal of Molecular Reproduction Development 62:320-327.

Rodriguez-Alvarez, L \& Castro, F.O. 2010. Effect of nucleus transfer on gene expression in bovine embryos during early development. Journal of Acta Scientiae Veterinariae. 38: s509-s519, 2010. 
Roth, Z., \& Hansen, PJ., 2004. Involvement of apoptosis in disruption of developmental competence of bovine oocytes by heat shock during maturation. Journal of Biology Reproduction 71:1898-1906.

Roth, Z., \& Hansen, P.J. 2005. Disruption of nuclear maturation and rearrangement of cytoskeletal elements in bovine oocytes exposed to heat shock during maturation. Journal of Reproduction:1741-7899.

Ritossa F. A new puffing pattern induced by temperature shock and DNP in Drosophila. Experientia 1962; 18:571-3.

Rynkowska, A., Rąpała, L., Trzeciak, P., \& Duszewska, A., 2011. The application of in vitro cattle embryo production system to study the influence of elevated temperature on oocyte maturation, fertilization and early embryonic development. Journal of Biotechnology, Computational Biology and Bionanotechnology 92(1) 45-53.

Shamas-Din, A., Kale, J., Brian, L., \& David, W., Andrews, w., 2013. Mechanisms of Action of Bcl-2 Family Proteins. Journal of Cold Spring Harbor Perspectives in Biology. 5(4): a008714.

Sakahira, H., Enarl, M., \& Nagata, S., 1998. Cleavage of CAD inhibitor in CAD activation and DNA degradation during apoptosis. Journal of Nature, 391: 96-99.

Sakatani, M., Kobayashi, S., \& Takahashi, M., 2004. Effects of heat shock on in vitro development and intracellular oxidative state of bovine preimplantation embryos. Journal of Molecular Reproduction and development. 67:77-82.

Sakatani, M., Alvarez, N. V., Takahashi, M. \& Hansen. P. J., 2013. Consequences of physiological heat shock beginning at the zygote stage on embryonic development and expression of stress response genes in cattle. Journal of Dairy Science 95:3080-91.

Sakatani, M., Yamanaka, K., Ahmed, Z. B., Naoki, T., \& Masashi, T., 2015. Heat Stress During In Vitro Fertilization Decreases Fertilization Success by Disrupting AntiPolyspermy Systems of the oocytes. Journal of Molecular Reproduction and Development 82:36-47.

Santos, E.R., DA Silva, J.C.F., Moura, T.M., Bartolomeu, C.C., Gonçalves, P.B.D., Delima, P.F., \& DE oliveira, M.A.L., 2010. Evaluation of sheep oocytes submitted to heat stress induced during in vitro maturation. Journal of Ciência animal Brasileira., Goiânia, 14: 360- 365.

SAS Institute, Inc. 1999. SAS/STAT User's Guide, Version 9, 1st printing, Volume 2. SAS Institute Inc, SAS Campus Drive, Cary, North Carolina 27513.

Satrapa, R. A., Nabhan, T., Silva, C. F., Simões, R. A. K., Razza, E. M., Puelker, R. Z., Trinca, L. A., \& Barros, C. M., 2011. Influence of sire breed (Bos indicus versus Bos taurus) 
and interval from slaughter to oocyte aspiration on heat stress tolerance of in vitro produced bovine embryos. Journal of Theriogenology 76:1162-1167.

Schrock, G, E., Saxton, A, M., Schrick, F, N., \& Edwards, J, L., 2007. Early in vitro fertilization improves development of bovine ova heat stressed during in vitro maturation. Journal of Dairy Science $90: 4297-4303$.

Silva, C.F. Sartorelli, E.S. Castilho, A.C. Satrapa, R.A. Puelker, R.Z. Razza, E.M. Ticianelli , J.S. Eduardo, H.P. Loureiro, B. and Barros, C.M., 2013. Effects of heat stress on development, quality and survival of Bos indicus and Bos taurus embryos produced in vitro. Journal of Theriogenology $79: 351-7$.

Silvia, F. C., Lilian, J. O., Hansen, P.J., 2009. Repression of induced apoptosis in the 2- cell bovine embryo involves DNA methylation and histone deacetylation. Journal of Biochemical and Biophysical Research Communications, 388: 418-421.

Sirard, M.A. 2001. Resumption of meiosis: Mechanism involved in meiotic progression and its relation with developmental competence. Journal of Theriogenology 55: $1241-1254$.

Skinner, M.K, 2005. Regulation of primordial follicle assembly and development. Human. Journal of Reproduction11: 461-471.

Smith C., 1988: Genetic improvement of livestock. World Animal Review 65: 2-10.

Smith, M.L., \& Sklar, S.D., 1986. Cloning and structural analysis of cDNAs for bcl-2 and a hybrid bcl-2/immunoglobulin transcript resulting from the translocation. Journal of Cell 47: 19-28.

Somal, A., Aggarwal, A., \& Upadhyay, R.C., 2015. Effect of thermal stress on expression profile of apoptosis related genes in peripheral blood mononuclear cells of transition Sahiwal cow. Iranian Journal of Veterinary Research.

Sreenan, J.M., 1970. In vitro maturation and attempted fertilization of cattle follicular oocytes. Journal of Agricultural Science 75 393-396.

Steptoe, P., Leroy, F., Finn, C.A., Psychoyos, A., Hubinont, P.O., 1980. Establishing pregnancies by replacing human embryos grown in culture. In: BlastocystEndometrium Relationships, vol. 7. Karger, Basel, pp. 324-336.

Sturmey, R. G., O'Toole, P.J., Leese, H.J., 2009. Fluorescence resonance energy transfer analysis of mitochondrial:lipid association in the porcine oocyte. Journal of Reproduction 132:829-837.

Suthar, V. S., \& Shah, R. G. 2009. Bovine In vitro Embryo Production: An Overview. Journal of Veterinary World, Vol.2 (12):478-479.

Telford, N.A., Watson, A.J. \& Schultz, G.A., 1990. Transition from maternal to embryonic control in early mammalian development: a comparison of several species. Journal of Molecular Reproduction Development. 26: 90-100. 
Thornton, P., 2010. Vulnerability, climate change and livestock-Research opportunities and challenges for poverty alleviation. SAT e Journal, 4, 1-23.

Vandaela, L., Goossens, K., Peelman, L., 2008. mRNA expression of Bcl-2, Bax, caspase-3 and -7 cannot be used as a marker for apoptosis in bovine blastocysts. Journal of Animal Reproduction Science. 106: 168-173.

Van Marle-Köster, E \& Webb, E.C., 2014. A perspective on the impact of reproductive technologies on food production. http://www.ncbi.nlm.nih.gov/pubmed/24170361

Verma, O.P, Kumar, R, Kumar, A \& Chand, S., 2012. Assisted Reproductive Techniques in Farm Animal-From Artificial Insemination to Nanobiotechnology. Veterinary World 5 (5): 301-310.

Viana, J. H.M., Siqueira, L.J.B., Miller, P. P., \& De Almeida Camargo, L.S., 2010. Use of in vitro Fertilization Technique in the Last Decade and its Effect on Brazilian Embryo Industry and Animal Production. Journal of Acta Scientiae Veterinariae 38: 661-s674..

Vilarino, M., \& Ross, P., 2015. The 'art' of delivering genomics to the beef herd. Proceedings, Applied Reproductive Strategies in Beef Cattle - August 17 \&18, $2015 \cdot$ Davis, CA.

Viuff, D., Hendriksen, P.J., Vos, P.L., Dieleman, S.J., Bibby, B.M., Greve, T., Hyttel, \& P., Thomsen, P.D., 2001. Chromosomal abnormalities and developmental kinetics in in vivo-developed cattle embryos at Days 2 to 5 after ovulation. Journal of Biology Reproduction 65:204-208.

Wan, P., Wang, B., \& Wang, Z., 2015. Importance of the stem cell microenvironment for ophthalmological cell-based therapy. World journal of stem cell 7:2.

Weil, M., Jacobson, M.D., Coles., H.S., Davies, T.J., Gardner, R.L., Raff, K.D., Raff, M.C.,1996. Constitutive expression of the machinery for programmed cell death. Journal of Cell Biology 133:1053-1059.

Warzych, E., Wrenzycki, C., Peippo, J., \& Lechniak, D. 2007. Maturation medium supplements affect transcript level of apoptosis and cell survival related genes in bovine blastocysts produced in vitro. Journal of Molecular Reproduction Development. 74, 280-289.

Watson, A.J., De Sousa, P., Caveney, A., Barcroft, L.C., Natale, D., Urquhart, J. \& Westhusin, M.E., 2000. Impact of bovine oocyte maturation media on oocyte transcript levels, blastocyst development, cell number and apoptosis. Journal of Biology Reproducion 62: 355-64.

Widayati, D.T., 2012. Embryo Transfer as an Assisted Reproductive Technology in Farm Animals. Journal of Biological, Biomolecular, Agricultural, Food and. Biotechnological Engineering: 6:10. 
Wilfling, F., Weber, A Potthoff, S., Vögtle, F.N., Meisinger, C., Paschen, S.A., \& Häcker, G. 2012. BH3-only proteins are tail-anchored in the outer mitochondrial membrane and can initiate the activation of Bax. Journal of Cell Death Differerentiation, 19(8): 13281336.

Wrenzycki, C., Herrmann, D., Carnwath, J.W., Niemann, H., 1996. Expression of the gap junction gene connexin43 (Cx43) in preimplantation bovine embryos derived in vitro or in vivo. Journal of Reproduction and Fertility 108: 17-24.

Wrenzycki, C., Herrmann, D., \& Carnwath, J.W., 1999. Alterations in the relative abundance of gene transcripts in preimplantation bovine embryos culture in medium supplemented with either serum or PVA. Journal of Molecular Reproduction Development, 53: 8-18.

Wrenzycki, C., Herrmann, D., Korsawe, K., Hadeler, K.G., Niemann, H., 2000.Relative abundance of specific mRNAs in bovine embryos produced in vivo or in vitro employing two different culture systems. Journal of Theriogenology 53: 415.

Wrenzycki, A. Lucas-Hahn, D. Herrmann, E., Lemme, K., Korsawe, \& Niemann, H., 2002a. In Vitro Production and Nuclear Transfer Affect Dosage Compensation of the X-Linked Gene Transcripts G6PD, PGK, and Xist in Preimplantation Bovine Embryos. Journal of Biology of reproduction 66: 127-134.

Wrenzycki, D., Herrmann, A., Lucas-Hahn, E., Lemme, K., Korsawe, H., \& Niemann., 2002b. Gene expression patterns in in vitro-produced and somatic nuclear transfer-derived preimplantation bovine embryos: relationship to the large offspring syndrome. Journal of Animal Reproduction Science:82-83: 593-603.

Wrenzycki, C., Herrmann, D., Lucas-Hahn, A., Lemme, E., Korsawe, K., \& Niemann, H., 2004. Gene expression patterns in in vitro-produced and somatic nuclear transferderived pre-implantation bovine embryos: relationship to the large offspring syndrome. Journal of Animal Reproduction Science, 82-83: 593-603.

Wrenzycki, C., Herrmann, D., Lucas-Hahn, A., Korsawe, K., Lemme, E., \& Niemann, $H ., 2005$. Messenger RNA expression patterns in bovine embryos derived from in vitro procedures and their implications for development. Journal of Reproduction Fertilty and Develoment 17: 23-35.

Wu, B., \& Zan, L. 2012. Enhance Beef Cattle Improvement by Embryo Biotechnologies. Journal of Reproduction Domestic Animal 47: 865-871.

Yang, J., Liu, X.\& Bhalla, K., 1997. Prevention of apoptosis by bcl-2: release of cytochrome $C$ from mitochondria blocked. Journal of Science 275: 1129-36.

Yang, M.Y., \& Rajamahendran, R., 2002. Expression of $\mathrm{Bcl}-2$ and Bax proteins in relation to quality of bovine oocytes and embryos produced in vitro. Journal of Animal Reproduction Science 70: 159-69. 
Youle, R.J, \& Strasser, A., 2008. The BCL-2 protein family: opposing activities that mediate cell death. Journal of Natural Rev Molecular Cell Biology 9:47-59.

Yu, H., Lai, H., Lin, T., \& Lo, S.J, 2015. Autonomous and non-autonomous roles of DNase II during cell death in C. elegans embryos. Journal of Bioscience Reports I 35 / art: e00203 / doi 10.1042/BSR20150055.

Yuan, Y.Q., Van Soom, A., Coopman, F.O.J., Mintiens, K., Boerjan, M.L., Van Zeveren, A., De Kruif, A., \& Peelman, L.J., 2003. Influence of oxygen tension on apoptosis and hatching in bovine embryos cultured in vitro. Journal of Theriogenology 59: 15851596.

Zaraza, J., Oropeza, A., Korsawe, M.A K., Herrmann, D., Carnwath, J.W., Niemann, H. 2009. Developmental competence and mRNA expression of preimplantation in vitroproduced embryos from prepubertal and postpubertal cattle and their relationship with apoptosis after intraovarian administration of IGF-1). Journal of Theriogenology 74(1):75-89.

Zeron, Y., Ocheretny A., Kedar, O., Borochov, A., Sklan, D., Arav, A., 2001 Seasonal changes in bovine fertility: relation to developmental competence of oocytes, membrane properties and fatty acid composition of follicles. Journal of Reproduction 121: 447-454.

Zhao, Y., Brezina, P., Hsu, C.C., Garcia, J., Brinsden, P.R., \& Wallach, E., 2011. In vitro fertilization: four decades of reflections and promises. Journal of Biochimica et Biophysica Acta 1810, 843-852.

Zheng, P., Vassena, R., \& Latham, K. E., 2007. Effects of in vitro oocyte maturation and embryo culture on the expression of glucose transporters, glucose metabolism and insulin signaling genes in rhesus monkey oocytes and preimplantation embryos. Journal of Molecular human reproduction 13(6):361-71.

Zhou, J., Yao, J., \& Joshi, H.C., 2002 Attachment and tension in the spindle assembly checkpoint. Journal of Cell Science 115: 3547-3555.

Zimmermann, K.C., Bonzon, C., \& Green, D.R. 2001. The machinery of Programmed cell death. Journal of Pharmacology Therapeutics 92 57-70. 